\title{
Review \\ A Study on the Effect of Inlet Air Pollution on the Engine Component Wear and Operation
}

\author{
Tadeusz Dziubak * (D) and Sebastian Dominik Dziubak (D)
}

Citation: Dziubak, T.; Dziubak, S.D. A Study on the Effect of Inlet Air Pollution on the Engine Component Wear and Operation. Energies 2022, 15, 1182. https://doi.org/10.3390/ en15031182

\section{Academic Editor: Flavio Caresana}

Received: 13 January 2022

Accepted: 2 February 2022

Published: 5 February 2022

Publisher's Note: MDPI stays neutral with regard to jurisdictional claims in published maps and institutional affiliations.

Copyright: (C) 2022 by the authors. Licensee MDPI, Basel, Switzerland. This article is an open access article distributed under the terms and conditions of the Creative Commons Attribution (CC BY) license (https:// creativecommons.org/licenses/by/ $4.0 /)$.
Faculty of Mechanical Engineering, Military University of Technology, 2 gen, Sylwestra Kaliskiego St., 00-908 Warsaw, Poland; sebastian.dziubak@wat.edu.pl

* Correspondence: tadeusz.dziubak@wat.edu.pl; Tel.: +48-261-837-121

\begin{abstract}
This paper systematically reviews the research progress in the field of the influence of air pollutants in the engine inlet on the accelerated wear of the elements of the association: piston, piston rings, cylinder liner (P-PR-CL), and plain bearing (journal-panel). It was shown at the outset that the primary component of air pollution is road dust. Its main components are dust grains of hard minerals $\left(\mathrm{SiO}_{2}, \mathrm{Al}_{2} \mathrm{O}_{3}\right)$, which penetrate the oil film area between two frictionally mating surfaces causing their abrasive wear. Therefore, the effect of three dust parameters (grain size and hardness, and dust concentration in air) on the accelerated wear of the friction pair: piston, piston rings, cylinder liner(P-PR-CL), and plain bearing (journal-pan) is presented extensively. It was noted that the wear values of the same component were obtained by different researchers using different testing techniques and evaluated by different indices. It has been shown that the greatest wear of two frictionally cooperating surfaces is caused by dust grains with sizes equal to the thickness of the oil film at a given moment, which in typical combustion engine associations assumes varied and variable values in the range of 0-50 $\mu \mathrm{m}$. The oil film thickness between the upper ring and the cylinder liner varies and depends on the crankshaft rotation angle, engine speed and load, and oil viscosity, and takes values less than $10 \mu \mathrm{m}$. It was shown that the maximum wear of the cylinder liner, resulting from the cooperation with the piston rings, occurs in the top dead centre (TDC) area and results from unfavorable (high temperature, low piston speed) operating conditions of these elements. From the extensive literature data cited, it follows that abrasive wear is caused by dust grains of specific dimensions, most often 5-20 $\mu \mathrm{m}$, the greater the wear the greater the hardness of the grains and the sulfur content of the fuel. At the same time, it was shown that the main bearing, crankshaft bearing, and oil ring experienced maximum wear by a different range of particle size, respectively: $20-40,5-10$, and 20-80 $\mu \mathrm{m}$. It was shown that the mass of dust that enters the engine cylinders and thus the wear of the components is determined by the concentration of dust, the value of which is definitely reduced by the air filter. However, it was pointed out that the low initial filtration efficiency and the presence of large dust grains in the purified air in the initial period of the filter operation (after replacement of the filter element with a new one) may have an impact on the accelerated wear of mainly (P-PR-CL) association. The next stage of the paper presents the effects of excessive wear of the cylinder liner and piston rings of the engine, resulting from actual vehicle operation and bench tests on the decrease in compression pressure and engine power, increase in the intensity of exhaust gas blow-by into the oil sump and increase in oil consumption and exhaust gas toxicity. This paper addresses the current problem of the effect of engine inlet air contaminants on the performance of the air flow meter, which is an essential sensor of the modern internal combustion engine. The phenomenon of deposition of contaminants (mineral dust, salt, carbon deposit, and moisture) on the measuring element (wire or layer anemometer) of the air flow meter has been analyzed. The empirical results presented show that the mineral dust layer on the measuring element of the air flow meter causes a $17.9 \%$ reduction in output voltage, and the dust and oil layer causes a $46.7 \%$ reduction in output voltage. This affects the decrease in engine power and exhaust toxicity.
\end{abstract}

Keywords: mechanical engineering; internal combustion engines; air pollution; engine component wear; power loss 


\section{Introduction}

In recent decades, dust pollution has been widely recognized as a serious environmental and engineering problem affecting the reliability of mechanisms and machines from nano to macro scale [1]. No industrial sector is immune to this problem, mainly affecting equipment that requires clean environments for proper operation and as intended. Examples of engineering applications where cleanliness requirements are high are mainly all lubricated machine components in relative motion (bearings, gears, axles, motor pistons, dynamic seals, etc.), miniature devices such as microelectromechanical systems, valves, mechanisms, and machines in the food, medical and pharmaceutical, aerospace, and electronics industries.

Contaminants found in machine associations come from a variety of sources. These can be residues from manufacturing and assembly processes or created by abrasive wear on machine components. Contaminants can be introduced from the environment or during equipment maintenance.

The problem of solid contaminants has arisen due to increased loads and tighter tolerances, as well as the miniaturization of equipment. Loads and tolerances mean that the lubricating film in contacts such as the ball-race in a rolling bearing, the pivot-cup association of a plain bearing, and the piston-ring-cylinder system has generally been reduced, making the mating surfaces more susceptible to increasingly smaller particles. Miniaturization means that small particles now have a greater impact because the ratio of particle size to the size of the parts involved has increased.

Modern engineering practice and research has shown the deleterious effects of particles as small as $0.1-100 \mu \mathrm{m}$ in contact with typical oil films on the order of a few nanometers to a few micrometers [1]. Each time a particle is compressed into narrow gaps, it inevitably creates local surface stresses that are elastic (reversible) at best and plastic (permanent) at worst. Any surface damage depends on the size, hardness, and fracture toughness of the particle, the hardness of the surface, the coefficient of friction at the "particle-surface" interface, the relative velocity of the surface, and the type of contact, i.e., rolling, sliding, spinning, or a combination thereof. Thus, various failure modes such as denting, abrasion, thermal damage, peeling, chipping, and even scuffing have been recognized.

The problem of the durability of internal combustion engines is closely related to the purity of the air drawn into the engine from the environment. Internal combustion engines of motor vehicles are particularly affected by particulate pollutants that are found in the air drawn from the atmosphere which is the primary operating medium of the engine. The engine needs at least $14.5 \mathrm{~kg}$ of air to burn $1 \mathrm{~kg}$ of fuel. When operating at rated conditions, passenger car engines draw about $150-400 \mathrm{~m}^{3} / \mathrm{h}$ of air and truck engines in the range of 900-1400 $\mathrm{m}^{3} / \mathrm{h}$. A T-72 tracked vehicle engine needs more than $3500 \mathrm{~m}^{3} / \mathrm{h}$ of ambient air to operate.

There is a large variety of solid and gaseous pollutants in the ambient air which are drawn in with the air by internal combustion engines. Along with fuel and oil, pollutants also enter the engine cylinders, but their quantity is much smaller. The concentration and type of pollutants in the air depends on many factors, such as the type and condition of the ground, the presence of vegetation, the type of industrial plants, the activities of the automobile, forest and landfill fires, and volcanic eruptions.

The sources of pollutants emitted into the atmosphere (dusts and gases) are many and varied. In general, they can be divided into natural and anthropogenic (artificial). Pollutants emitted to the atmosphere (dust and gases) can be both primary, emitted directly to the atmosphere, and secondary, formed in the atmosphere as a result of chemical reactions.

Natural pollutants result from the activities of nature and include:

- Volcanic eruptions, which produce volcanic ash and the gases $\mathrm{SO}_{2}, \mathrm{CO}_{2}, \mathrm{H}_{2} \mathrm{~S}$, among others;

- $\quad$ Forest, savannah, and steppe fires $\left(\mathrm{CO}_{2}, \mathrm{CO}\right.$, and dust emissions);

- Dump fires;

- Marine aerosols, and material of plant and animal origin;

- $\quad$ Marshes that give off gases, for example: $\mathrm{CH}_{4}, \mathrm{CO}_{2}, \mathrm{NH}_{3}, \mathrm{H}_{2} \mathrm{~S}$; 
- Mineral dust carried from the ground by motor vehicle traffic, activity of working and agricultural machines;

- Erosive soils and rocks, mineral dust carried from the ground by the wind-sandstorms;

- Biological contamination: microorganisms (mites, fungi, bacteria), plant pollens, parasites;

- Green areas from which pollen comes.

Artificial pollutants result from human activities and include:

- Energy industry-burning of fuels in heating plants and power plants;

- Mining industry, metallurgical industry, chemical industry, construction industry (production of cement) emitting to the atmosphere large amounts of dusts and harmful gases $\left(\mathrm{NH}_{3}, \mathrm{H}_{2} \mathrm{~S}, \mathrm{HCl}\right)$ and heavy metals;

- Municipal and household sector (households), collection and disposal of waste and sewage, e.g., landfills, sewage treatment plants;

- Motorization-mainly road transport, but also water and air transport being the source of atmospheric emissions of gaseous pollutants originating from the process of combustion of engine fuels: $\mathrm{CH}, \mathrm{CO}, \mathrm{NO}_{\mathrm{x}}, \mathrm{SO}_{3}, \mathrm{SO}_{2}, \mathrm{PM} 2.5$, and PM10 particulates and chemical compounds, as well as dusts, from abrasion of tires and road surfaces, brake pads, and discs and clutch discs.

In the overall stream of pollutants that are introduced into the atmosphere surrounding the earth, $85 \%$ are pollutants of natural origin. These are dusts and harmful gases.

The users of vehicles are interested in these pollutants that, when they get inside the engines together with the air, have a destructive impact on engine parts and assemblies, causing their accelerated wear, which results in the reduction of effective parameters of engine operation and in their reduced durability and reliability. These are mineral dusts found in the air mainly during the operation of vehicles on unpaved roads and off-roads. Mineral dust is one of the dominant constituents of atmospheric aerosols and accounts for $\sim 60 \%$ of the dry aerosol mass globally [2]. This applies mainly to special-purpose vehicles, work machines, and military vehicles equipped with high-powered internal combustion engines and high air demand.

Passenger cars and trucks travel mainly on paved roads, whose surfaces are the place of deposition of particles from many different sources. First and foremost is mineral dust that has been carried by the wind from soils surrounding the road, generated from field work or road construction activities, and from sandy and desert areas that cover about one-third of the earth's surface [3]. Large amounts of dust are generated by open pit coal mine operations [4-6].

The road surface may contain salt used for de-icing roads, plant fragments, pollen, animal hair and mold, and other biological materials carried from nearby locations $[7,8]$. The author of this paper [9] conducted an analysis of the contaminants retained on the filter. The contaminant particles varied greatly in size, shape, and chemical composition. The contaminants with the largest sizes were biological material visible to the naked eye. These included small insects such as beetles, wasps, bees, and flies, as well as their legs, feelers, and wings. Plant remains, represented by fragments of wood, seeds, and leaves, were also observed, though less frequently. Inorganic particles and synthetic fibers were also found. Analysis of dust particles retained on the filter showed that the most abundant elements found in large irregular particles were $\mathrm{C}, \mathrm{O}, \mathrm{Si}, \mathrm{Al}, \mathrm{Ca}, \mathrm{Mg}, \mathrm{Na}, \mathrm{K}, \mathrm{Ti}, \mathrm{Fe}$, and $\mathrm{Si}$ [9].

A significant amount of particulate pollution is generated by anthropogenic activities such as agriculture, industrial production. Pollutants from anthropogenic sources are also particles that have been released into the atmosphere as a result of abrasion processes in the friction pairs of brakes and clutches of cars [10-13] and as a result of abrasion of the tire tread against the road surface, which then fall by gravity [14-18]. It has been shown in [17] that under actual operating conditions, the mass of a car and the intensity of braking have a significant effect on the emission of PM2.5 and PM10 particles from brake and tire wear. The highest concentrations of PM2.5 $\left(520-4280 \mu \mathrm{g} / \mathrm{m}^{3}\right)$ and PM10 $\left(950-8420 \mu \mathrm{g} / \mathrm{m}^{3}\right)$ particles from brake wear were observed for the vehicle with the highest mass, while the lowest peak concentrations of PM2.5 $\left(250-2440 \mu \mathrm{g} / \mathrm{m}^{3}\right)$ and PM10 $\left(430-3890 \mu \mathrm{g} / \mathrm{m}^{3}\right)$ were observed 
for the vehicle with the lowest mass. Similarly, the highest PM2.5 $\left(340-4750 \mu \mathrm{g} / \mathrm{m}^{3}\right)$ and PM10 $\left(810-8290 \mu \mathrm{g} / \mathrm{m}^{3}\right)$ concentrations were from the tires of the highest mass vehicles. As expected, vehicles with lower mass emitted much lower PM2.5 $\left(340-4750 \mu \mathrm{g} / \mathrm{m}^{3}\right)$ and PM10 $\left(810-8290 \mu \mathrm{g} / \mathrm{m}^{3}\right)$ concentrations from tire wear.

The internal combustion engines of automobiles are the source of emissions of a significant amount of exhaust gases, which include non-toxic $\left(\mathrm{N}, \mathrm{O}, \mathrm{H}_{2} \mathrm{O}, \mathrm{CO}_{2}, \mathrm{H}\right)$ and toxic $(\mathrm{CO}$, $\mathrm{NO}_{x}, \mathrm{CH}, \mathrm{SO}_{2}, \mathrm{RCHO}, 3,4$-benzopyrene) components [19,20]. Internal combustion engines also emit PM (particulate matter), which are formed by complex chemical and physical processes occurring during fuel combustion in the engine cylinder and exhaust [19-22]. Particulate matter (PM) is soot which is a by-product of incomplete and incomplete combustion of fuel, on the surface of which there are: unburned hydrocarbons from fuel and lubricating oil, water vapor, sulfur and nitrogen compounds, and ash, as well as products of frictional wear of metal elements from frictionally cooperating engine joints [23].

Road surfaces are primarily a deposition site for mineral dust that has been carried by the wind from soils surrounding the road, generated by field work, or from road construction activities. Falling atmospheric dust has a complex mineral-chemical composition. The diameter of these particles is greater than $10 \mu \mathrm{m}$ and less than $100 \mu \mathrm{m}$ [24]. Its basic constituents are silica $\left(\mathrm{SiO}_{2}\right)$ and alumina $\left(\mathrm{Al}_{2} \mathrm{O}_{3}\right)$, whose hardness evaluated on the Mohs 10-point scale has a value of 7 and 9, respectively. The proportion of these two components of mineral dust reaches $60-95$. The residue (4-19\%) consists of oxides of various metals: $\mathrm{F}_{2} \mathrm{O}_{3}, \mathrm{CaO}, \mathrm{MgO}$, and organic components $[25,26]$. The road surface also contains particles that have been released into the atmosphere as a result of abrasion processes in the friction pairs of brakes and clutches and as a result of the abrasion of the tire tread against the road surface, which then fall by gravity. Roads contain pollutants that are expelled from engines with exhaust gases, such as soot and wear products of frictionally mating engine components. The road surface may contain de-icing salt, plant fragments, pollen, animal hair and mold, and other biological materials carried from nearby locations. Contaminants on the road surface, due to vehicle traffic or by wind, are lifted up as dust, which is commonly referred to as road dust [27-29].

In the case of motor vehicles, airborne dust is hazardous and when it enters the engine, it can degrade engine performance. Silica and corundum are the cause of accelerated wear of cooperating and key engine components, such as piston rings and cylinder liners, crankshaft journals and bushings, valves, and guides. The minimum service life of these parts determines the life of the engine.

Impurities which are sucked with air into engine cylinders have different chemical and granulometric composition and moreover their content in air (dustiness) is variable and depends on many factors: terrain conditions, type of road, traffic conditions (traffic volume, traffic speed, traffic of other vehicles, share of studded tires and exhaust emissions), meteorological conditions (types of precipitation and their frequency, wind direction, and strength), road surface condition (dry, wet, covered with ice, sprinkled with salt or sand), vehicle design and its running gear (wheeled, tracked), and location and design of the air intake to the engine.

Dust concentration values in the air vary within wide limits, from $0.01 \mathrm{mg} / \mathrm{m}^{3}$ near rural buildings to about $20 \mathrm{~g} / \mathrm{m}^{3}$ when a column of tracked vehicles is moving over desert ground [30]. During dust storms, the dust concentration takes values in the range of $0.1-3 \mathrm{~g} / \mathrm{m}^{3}$ [31]. According to the author of the paper [32], the dust concentration in the air can take values in the range of $0.001-10 \mathrm{~g} / \mathrm{m}^{3}$. The maximum values of dust concentration in the air within a few meters of the sand road on which off-road vehicles traveled was variable in a wide range of $0.05-10 \mathrm{~g} / \mathrm{m}^{3}$ [33]. The dust concentration on highways takes small values but in a wide range of $0.0004-0.1 \mathrm{~g} / \mathrm{m}^{3}$, while during the movement of a column of vehicles on a sandy terrain the dust concentration takes much larger values $0.03-8 \mathrm{~g} / \mathrm{m}^{3}$ [34].

Dust concentrations on streets depend on traffic volume, but typically range from 0.09 to $0.13 \mathrm{mg} / \mathrm{m}^{3}$. Much higher dust concentrations, reaching up to $0.65 \mathrm{mg} / \mathrm{m}^{3}$, have been 
measured while passing through a tunnel, where heavy traffic, high speed, and confined space created favorable conditions for high dust concentrations [35].

The author of the paper [36] states that the concentration of dust in the air behind a moving column of trucks, armored personnel carriers, and tracked vehicles depends on the type of ground, vehicle speed, wind speed, and the type of chassis. At a distance of several meters behind a column of tanks moving at 30 and $10 \mathrm{~km} / \mathrm{h}$ on dry ground, the dust concentration reached a maximum value of 1.17 and $0.48 \mathrm{~g} / \mathrm{m}^{3}$, respectively. The authors of the paper [37] report that the dust concentration at the periphery of the armor of a tracked vehicle operated over sandy terrain increases with increasing driving speed and for $18 \mathrm{~km} / \mathrm{h}$ takes values in the range of $2.1-3.8 \mathrm{~g} / \mathrm{m}^{3}$. At the air filter inlet, the concentration has much lower values and is $0.8-1 \mathrm{~g} / \mathrm{m}^{3}$.

Numerous studies show that the dust concentration at the inlet to the vehicle combustion engine intake system usually does not exceed $2.5 \mathrm{~g} / \mathrm{m}^{3}$ [32,33]. A dust concentration in the air of $0.6-0.7 \mathrm{~g} / \mathrm{m}^{3}$ is the reason for reduced visibility, and at a concentration of about $1.5 \mathrm{~g} / \mathrm{m}^{3}$, visibility decreases to zero [38].

The concentration of dust inside a car with open windows was about $2.5 \mathrm{mg} / \mathrm{m}^{3}$ [39] when it was moving behind another car on a gravel road.

The author of the paper [31] divides the road conditions on which most cars and light trucks travel into two groups:

- Normal driving conditions (streets, highways, residential, and rural roads) with dust concentrations below $1 \mathrm{mg} / \mathrm{m}^{3}$;

- Severe driving conditions (gravel roads, desert areas) with dust concentrations higher than $1 \mathrm{mg} / \mathrm{m}^{3}$.

Dust, which is sucked with air into engine cylinders, only partly takes part in destructive influence on engine elements. The authors of [40] state that about $30 \%$ of the pollutants getting with the air into the engine super-piston space may get out in basically the same form with the exhaust gases from cylinders to the exhaust system. This increases the emission of particulate matter (PM) from the engine

The dust particles contained in the exhaust gas cause erosive wear to the exhaust valves and turbine blades of the supercharger as a result of the high velocity of the exhaust gas flowing through narrow valve gaps. Some of the dust particles whose melting point is much lower than the average temperature in the combustion chamber (1600K) melt [41]. Only $10-20 \%$ of the dust that enters the engine through the intake system settles on the cylinder liner walls. This part of the dust forms together with oil a kind of abrasive paste, which in contact with the surfaces of the piston-piston ring-cylinder (P-PR-CL) association causes abrasive wear. As the piston moves in the bottom dead center (BDC) direction, the rings scrape the oil from the cylinder face together with the contamination into the oil sump. The contaminants contained in the oil are distributed via the oil system to those areas of the engine that are lubricated by oil, e.g., crankshaft journal-crankcase, camshaft journalcrankcase, valve guide-valve stem, causing accelerated wear. The primary role of the piston ring pack is to maintain an effective gas seal between the combustion chamber and the crankcase. Piston rings fulfil this task by forming a labyrinth seal by fitting tightly into the grooves in the piston and the cylinder wall. The tribological effect of piston rings causes their wear. Within the framework of works on the development of internal combustion engines, it was found that the course of wear of the friction pair "ring-cylinder liner" and the distribution of the oil film is largely influenced by the flow of exhaust gases and their degree of contamination in the labyrinth seals of piston rings [42]. It has been indicated that this process is exacerbated when the maximum operating pressure in the combustion chamber is high and insignificant total cylinder volumes are used [43]. The wear of the cylinder liner and piston ring pack has a significant effect on the loss of tightness of this association and consequently on the performance of internal combustion engines due to the loss of compressed medium and loss of power, increase in fuel and oil consumption [44-46]. There is also an increase in exhaust gas blow-by into the crankcase, which causes an increase in the temperature of the mating parts and the lubricant, which reduces its viscosity. There 
is then a high susceptibility to oil film discontinuity between the kinematic pairs of the main engine mechanism [47]. The second function of piston rings is to transfer heat from the piston to the cylinder walls and from there to the engine coolant. Another function of the piston ring package is to reduce the amount of oil that enters the combustion chamber from the crankcase. This flow path is a primary contributor to engine oil consumption and leads to increased emissions of toxic exhaust components as a result of oil mixing and reacting with hot exhaust gases.

The friction pair consisting of the cylinder liner and piston rings (P-PR-CL) are the basic components of the friction linkage of the engine piston-crank system, which, due to the extremely harsh operating conditions resulting from the action of high temperature (oil viscosity drop) and high pressure and high forces for a long time, are particularly susceptible to wear and have a significant impact on engine efficiency and service life [48-50]. According to the authors of works [48,51-57], depending on the type of engine and its operating conditions, $20-50 \%$ of friction losses in internal combustion engines occur in frictional contact between the piston ring assembly and the cylinder liner. Friction results in the loss of the major part (48\%) of the energy produced in the engine, of which the friction losses of the piston shell, piston rings, and bearings comprise $66 \%$, and the valve train, crankshaft, transmission, and gears account for about 34\% [58]. A small reduction in friction can result in significant savings in fuel consumption, given the large number of vehicle systems operating daily in the world. There are an estimated 1.2 billion light-duty vehicles and 380 million heavy-duty vehicles in the world, and these numbers continue to grow [59].

The energy demand of the transportation sector is enormous, with daily liquid fuel requirements exceeding about 11 billion liters. Stringent emission standards have forced the automotive sector to significantly improve the tribological behavior of engine systems. Advances in the tribology of engine systems may be a more economical alternative than developing new technologies to achieve better engine performance. Analysis of energy loss in an internal combustion engine can show that about $15 \%$ of the total fuel energy is lost due to mechanical friction. A $1.5 \%$ reduction in fuel consumption can be achieved with a $10 \%$ reduction in mechanical losses. In addition to reducing fuel consumption, tribological improvements can also reduce oil consumption, reduce emissions, improve durability, and increase engine power [60].

The intensity of wear of engine elements depends on many factors, including the operating conditions of the engine (rotational speed, load), which is connected with creating the appropriate thickness of the lubrication wedge between the mating surfaces of engine elements. The decisive influence on the wear of friction mating surfaces has the parameters of dust sucked in with the air, whose values change within wide limits and depend on the conditions in which the engine is used. The amount of wear on the "cylinder-ring" friction couple is also influenced by the type and quality of fuel and the parameters of its injection into the cylinder. This is mainly manifested in the context of deposits formation on engine elements and exhaust emission. To this end, work is being done to optimize the performance and reduce exhaust emissions of engines tested on unconventional fuels [61-67].

One of the major causes of increased engine wear, especially with most engine manufacturers opting for exhaust gas recirculation (EGR) technology to reduce nitrogen oxide $\left(\mathrm{NO}_{\mathrm{x}}\right)$ emissions [68-70] is soot contamination of engine oil [71-73]. Due to the increasing requirements to meet exhaust emissions, diesel engines and gasoline direct injection (GDI) engines are being equipped with catalytic particulate filters. This is an effective solution by which soot can be captured and burned $[74,75]$.

The current tendency in the construction of internal combustion engines to increase specific power results in the fact that the elements of the P-PR-CL assembly of an internal combustion engine are subjected to increasingly higher mechanical and thermal loads, which promotes their faster wear. The experience from exploitation shows that the continuous increase of engine power does not remain without influence on wear, durability and 
reliability of the most loaded elements (cylinder liner and piston rings), which determine the durability of the whole engine.

The purpose of this paper is an extensive and structured analysis of the influence of road dust, sucked together with air through the engine intake system, on the intensity of wear of engine elements with special attention paid to the P-PR-CL piston-ring-cylinder combination. A detailed analysis of the influence of the fuel type and injection system on the formation of deposits and their impact on the wear of engine elements was intentionally omitted in the analysis. The analysis of the soot effect on engine wear was also not considered. The authors are aware of the importance of these factors in the context of engine durability. It was considered that the paper would become too voluminous and the most important problem, i.e., the influence of mineral dust on engine wear, would not be properly exposed. It was pointed out that despite the use of inlet air filtration systems, mineral dust grains with dimensions less than $2-5 \mu \mathrm{m}$ enter the engine and are the cause of accelerated wear. Larger dust grains can only enter the engine cylinders if the filtration system fails. Modern tribological systems of internal combustion engines, due to the increasing thermal and mechanical loads on the engines, are characterized by increasingly smaller clearances and oil thickness between the friction pair surfaces. It is currently believed that mineral dust grains above $1 \mu \mathrm{m}$ cause accelerated wear.

The paper also analyzes the phenomenon of the effect of road dust and other air pollutants (salt, oil, moisture) that settle on the measuring element of the air flow meter causing a change in its characteristics. As a result, the information transmitted to the on-board computer and the mass of air flowing is incorrect, which interferes with engine operation causing a decrease in power. Data were quoted showing the influence of contaminants contained in the engine oil, where they enter from the air in contact with the cylinder liner, on the accelerated wear of elements of these associations, which are lubricated by oil. The paper draws attention to the effects that result from accelerated wear of engine components. The influence of excessive wear of PR-CL junction on the decrease of compression pressure, engine power and on the blow-by of cargo and exhaust fumes to the crankcase is presented. Innovative technologies were presented, e.g., texturing the surfaces of piston rings and cylinder liners, applying layers that reduce friction and prevent their increased wear. Attention was drawn to the necessity of using air filters of high efficiency and accuracy, especially in the case of vehicles operating in conditions of high dust concentration in the air. The number of available literature items concerning this problem is extensive; therefore, the authors used only selected items. In the available literature, there is no study which comprehensively covers the problem of the influence of the dimensions of dust grains, their hardness, and dust concentration on the wear of the PR-CL friction pair of an internal combustion engine. The results of wear of the elements obtained during laboratory tests, bench tests on an engine dynamometer, and during real engine operation were analyzed.

\section{The Effect of Dust in the Intake Air on Engine Component Wear}

The basic task of the air supply system is to supply the engine with air of the appropriate quantity and quality (purity), for which the air filter is responsible. The basic filter material of motor vehicle operating fluids are fibrous materials, mainly filter paper, which is characterized by high mass efficiency of over $99.9 \%$ and high accuracy of dust grains above $2-5 \mu \mathrm{m}$, but low dust absorption of about $200-250 \mathrm{~g} / \mathrm{m}^{2}$ [76-78].

Therefore, the engine inlet air (downstream of the filter) contains dust grains with sizes below $5 \mu \mathrm{m}$. Dust grains with larger sizes can enter with the air into the engine cylinders only in case of failure (leakage of connections) of the inlet system or loss of filtering properties of the paper cartridge.

The effects of dust particles contained in engine intake air and oil on engine components are varied and consist of (Figure 1):

- Abrasive wear of P-PR-CL coupling elements;

- Erosive wear of compressor and turbine;

- Abrasive wear of junction elements to which lubricating oil is supplied; 
- Settling of dust on the measuring element of the air flow meter;

- Settling of molten dust particles on the catalytic surface.

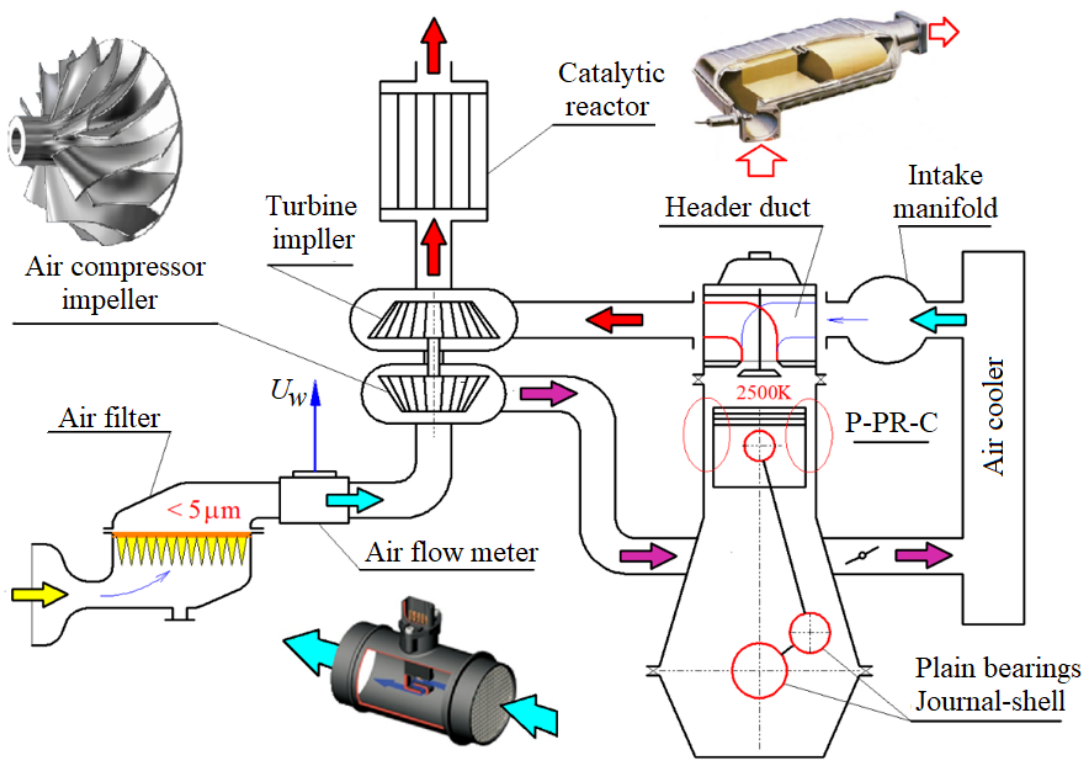

Figure 1. Functional diagram of the intake system of a motor vehicle combustion engine.

In machine operation, tribological wear processes are divided into the following processes: abrasive, adhesive, oxidative, fatigue, corrosive, and cavitation. From the point of view of filtration of exploitation fluids, the important processes are those that are caused by impurities in the fluids. This is wear caused by the abrasive action of loose solid particles of impurities. Abrasive wear is a phenomenon of destruction of the surface layer of cooperating bodies (moving in relation to each other) during friction as a result of the impact of roughness projections of one element on the surface layer of the other element. This movement is accompanied by dry or mixed friction. This type of wear consists in the fact that hard bumps or loose abrasive grains are embedded (pressed) in the surface layer of mating elements and during relative movement cause its destruction. During the operation of engines, the abrasive grains enter the mating fluids, mainly with the air Abrasive wear is a mechanical process. The character of the action of abrasive particles on the surface layer material depends mainly on the type of their relative motion and on the character and value of forces acting in the area of contact between the particle and the machine component.

In internal combustion engine systems, there are many friction pairs that require a lubricant for proper operation, which minimizes friction and reduces their wear value. The piston-ring-cylinder (P-PR-CL) friction pair is the primary assembly that determines the wear and life of an internal combustion engine. Other frictional pairs include the main and crankshaft and camshaft plain bearings (journal-crankcase), valve stem-guide, camshaft cam-valve galleries, piston pin-crankcase, and valve seat-valve seats (Figure 2). The tribological behavior of the (P-PR-CL) assembly has long been recognized as an important factor affecting the performance of internal combustion engines in terms of fuel consumption, power loss, oil consumption, emissions of harmful exhaust components, and working fluid blow-by into the crankcase.

The piston, which is the mobile combustion chamber closure, serves to convert the chemical energy of the fuel into useful kinetic energy. The primary role of the piston rings, which are pressed against the cylinder surface by elastic force, is to seal the gas flow between the combustion chamber and the crankcase. The piston rings, which are located in the piston grooves, move along the cylinder liner in a reciprocating motion with a high, but also variable sliding speed. In addition, the piston rings move axially and radially in the piston groove, rotate in the ring groove relative to the sleeve axis and deform, causing 
inclination relative to the cylinder liner. This can cause changes in the oil film parameters The pressure of the rings on the surface of the sleeve is assisted by the gas pressure acting on the rear part of the ring. When the total of the forces acting on the ring along the cylinder axis changes its direction, the ring breaks away from the lower piston groove surface and moves axially to the upper piston groove surface. This results in gas being blown into the crankcase. The cyclic piston ring movements cause oil to flow over the piston crown, which is burned off [79].

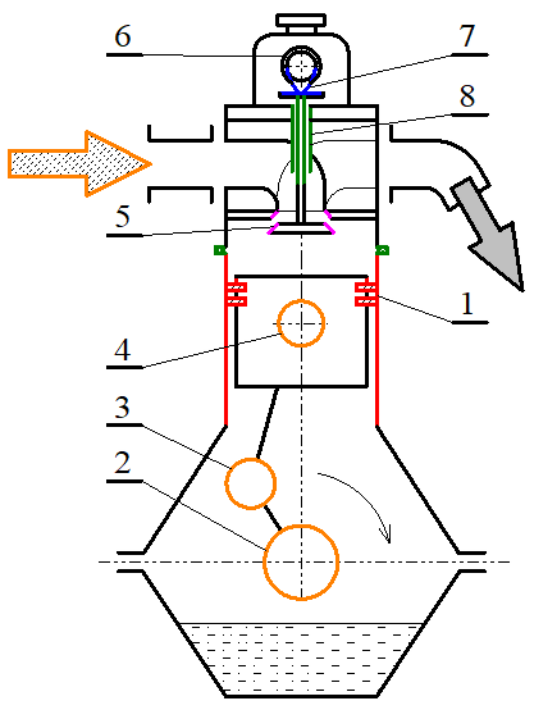

1 - piston rings cylinder (P-PR-CL)

2 - main bearing (journal-cup) of the crankshaft

3 - connecting rod sleeve bearing (journal - socket)

4 - piston pin - connecting rod head

5 - valve face - valve seat face

6 - camshaft plain bearing

7 - camshaft cam - valve roller

8 - valve stem - guide

Figure 2. Friction couplings in internal combustion engine systems.

The air flowing into the combustion chamber usually makes a helical motion towards the piston crown, which is caused by a suitably shaped intake duct. The inertia force acts on the dust grains in the airstream and directs the heavier grains to the cylinder surface where they are fixed in the oil film.

In the abrasive wear of the engine component surfaces, only that part of the dust grains that penetrated the engine's superstructure with the air and settled in the oil film on the cylinder liner wall are involved. The contamination grains suspended in the oil film, which are mainly of mineral origin, get between the two mating surfaces of the piston-piston ring-cylinder (P-PR-CL) or plain bearing (journal-shell) joint and form an oil film (Figure 3). If the minimum oil film thickness $h_{\min }$ between the mating surfaces is greater than the particle size $d_{p}$, there is no contact between the dust grains and the mating surfaces and they do not cause damage to the surfaces.

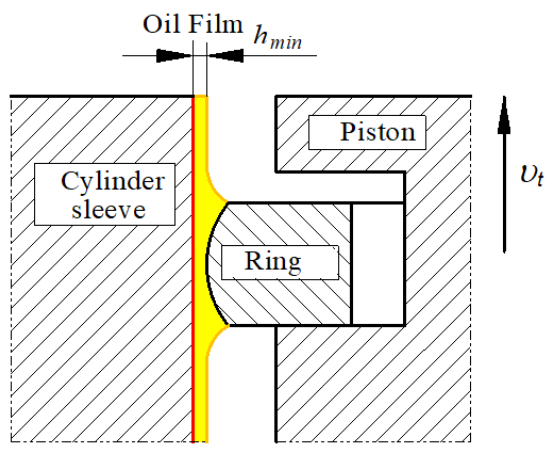

(a)

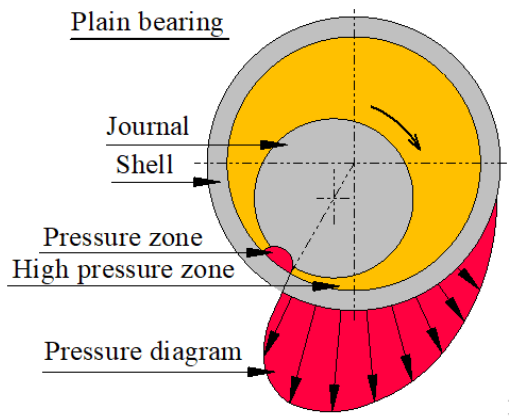

(b)

Figure 3. Oil film formation in the following combinations: (a) piston-piston rings-cylinder (P-PR-CL), (b) plain bearing: journal-shell. 
In an internal combustion engine, which operates with variable speed and load, the oil film thickness $h_{\text {min }}$ is not a constant value and depends directly proportional to the oil viscosity depending on the temperature, relative speed in the lubricated surfaces and inversely proportional to the loading force $N$ (engine load) according to the relation [80]:

$$
h_{\min }=C \frac{\eta \cdot v_{w}}{N}
$$

where $C$ - a coefficient that depends on the dimensions of the association elements.

Abrasive wear occurs when, as a result of an increase in the applied force $N$ (increase in load, increase in temperature and decrease in viscosity), two mating surfaces come into close proximity at a distance $d_{p}=h_{\min }$ (Figure 4 ). Dust grains are generally irregular lumps with sharp multilateral cutting edges. When a hard particle (mineral dust grain) has gained contact with two surfaces and the action of the force $\mathrm{N}$ does not give way, the particle usually penetrates one of the surfaces. The dust particle so fixed acts as a cutting tool causing micro-volume cutting and deformation of the layer of the opposite surface. The dust grains can cause scratching, furrowing, and break off metal shavings that are embedded in the material of the components that make up the engine's component assembly. In addition, engine components are subject to different loads, which changes the clearance values and oil operating conditions. Most of the dynamic clearances are in the range of $0-20 \mu \mathrm{m}$.

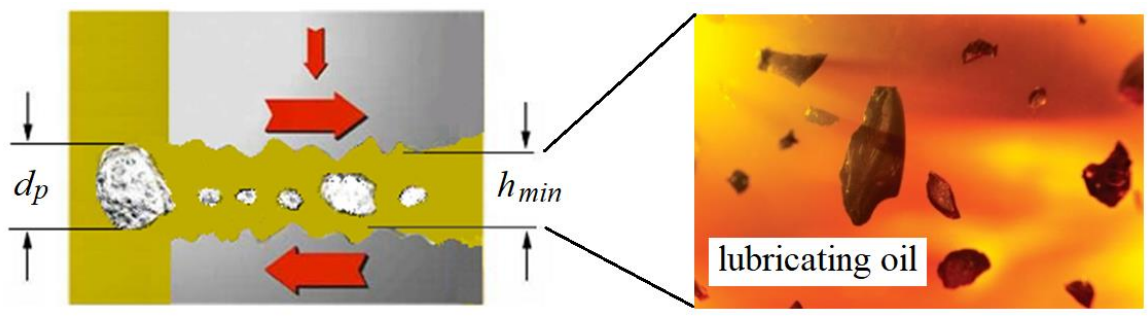

(a)

(b)

Figure 4. Effect of particulate matter on tribological pair: (a) impurities suspended in oil [81], (b) condition of maximum wear of the association. Figure made by the authors based on data from [82].

The prevailing view in the literature is that wear is caused by dust grains with size $d_{p}$ equal to the minimum $h_{\text {min }}$ thickness of the oil film between the mating surfaces at a given moment. For any other value of the $h_{\min } / d_{p}$ quotient, the association wear decreases [82,83]. Accurate calculation of this thickness is difficult, both in associations with reciprocating and rotating motion, because:

- The surface outline is not exactly geometric;

- The temperature and viscosity of the oil film changes;

- Unit pressures are constantly changing due to the cyclic nature of operation and varying engine load;

- The clearances in the linkages increase as the wear of the engine components increaseswith the increase of its service mileage.

Between the cylinder liner and piston rings, the oil film thickness is determined mainly by the piston velocity, which varies sinusoidally (Figure 5), and oil viscosity, which depends on the temperature of mating elements. The highest value of piston (piston ring) velocity, the most critical zone where intense wear occurs, is in the top dead center (TDC) area due to a combination of various adverse factors. The change in the direction of piston movement (alternate acceleration and deceleration) in the extreme positions of the cylinder liner causes its velocity to be the lowest in this area, and zero at BDC and TDC. This leads to a reduction in oil film thickness or its complete disappearance. P-PR-CL components are subjected to the highest temperature, resulting from direct contact with the hot exhaust gas, which causes a decrease in viscosity and lubricating wedge thickness. Consequently, there 
may be periods of even direct metallic contact between the piston ring and the bushing, resulting in increased friction coefficient and wear [84].

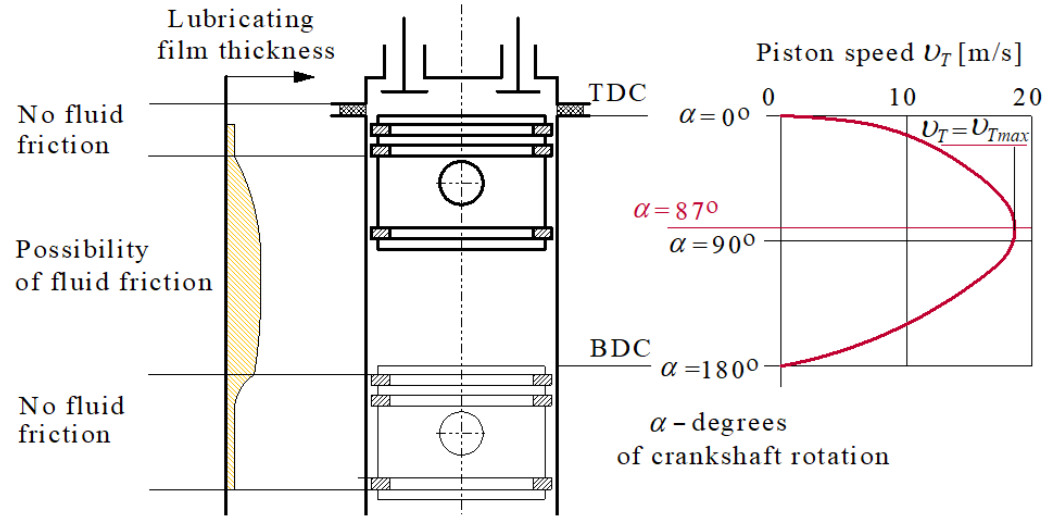

Figure 5. Effect of piston speed on lubrication wedge formation and lubrication film thickness.

The change in oil film thickness between the upper ring and cylinder liner as a function of crankshaft rotation angle for three $(800,3000,7000 \mathrm{rpm})$ The rotational speeds of the engine operating at full load are shown in Figure 6. The oil film thickness increases its value as the engine speed increases - the reciprocating motion speed increases [85]. The oil film thickness reached its maximum value in the middle of the stroke, where the piston speed is the highest, which induces hydrodynamic lubrication. For 800; 3000 and 7000 rpm, the oil film thickness at mid-stroke (90 and $450^{\circ}$ crank angle) varied from 0.7-1.5, 2.4-2.6, and 3.4-4 $\mu \mathrm{m}$, respectively. At BDC and TDC, the oil film thickness reaches minimum values. These are probably the points where the piston ring comes into metallic contact with the cylinder liner (boundary lubrication). Under these conditions theoretically any particle of arbitrarily small size can be the cause of wear.

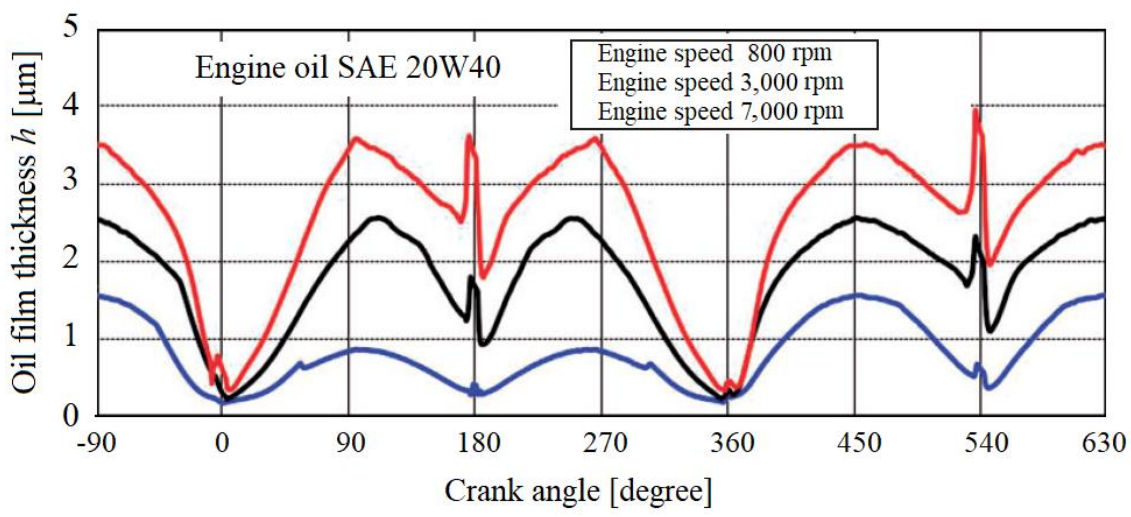

Figure 6. Effect of engine speed on oil film thickness between top ring and cylinder liner at SAE 20W40 engine oil. Figure made by the authors based on data from [85].

From the theoretical and experimental studies conducted by the authors of the paper [86], it can be seen that the minimum oil film thickness $h_{\text {min }}$ changes its value depending on the crankshaft rotation angle (piston position in the cylinder), which is influenced by the rotational speed, engine load and oil viscosity. During the compression stroke (3000 rpm, $40 \mathrm{Nm}$ load), the minimum thickness of the oil film on the sealing ring was $h_{\min }=9 \mu \mathrm{m}$, and during the operating stroke- $h_{\min }=5 \mu \mathrm{m}$, which is $50 \%$ less and results from the pressure of exhaust gases on the rear part of the ring.

As a result of changes in the thickness of the oil film between the mating surfaces, the dust grains found there may be crushed and fragmented. The resulting smaller grains can penetrate between the two mating surfaces where the oil film thickness takes on small 
values. In typical combustion engine mating, the oil film thickness reported by the authors of the paper [87] assumes varying values (Figure 7).

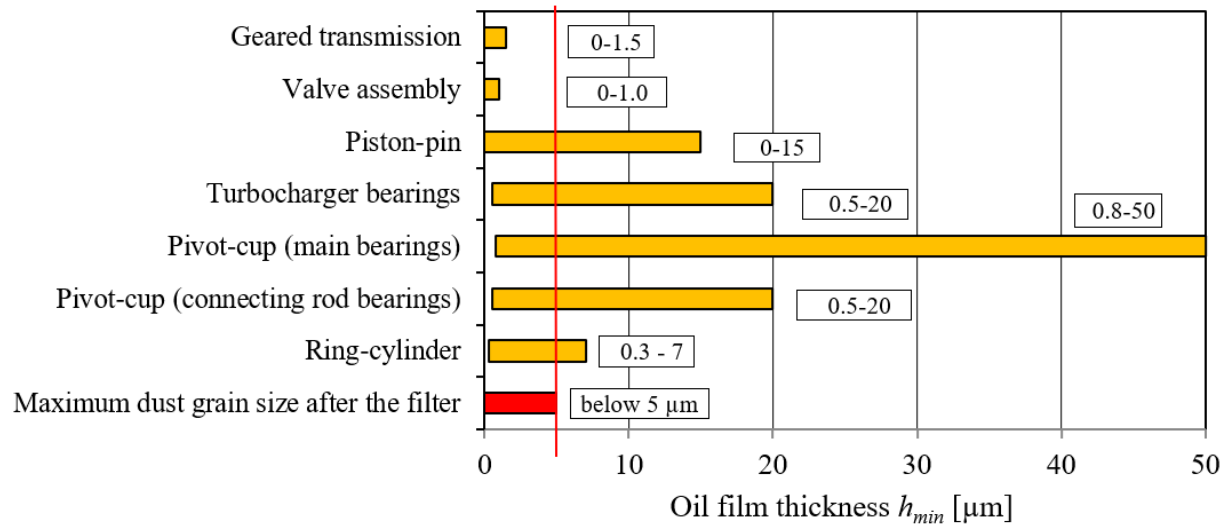

Figure 7. Oil film thicknesses in typical combustion engine associations. Figure made by the authors using data from [87].

It is believed that the abrasive aggressiveness of dust decreases when the dust grain sizes are less than $5 \mu \mathrm{m}$. Such a value is considered to be the upper acceptable size of dust grains that can be passed through air, fuel, and oil filters. Therefore, work is being undertaken to increase the filtration accuracy of dust grains in this range, for example by using nanofiber filter baffles [88-92].

Dust entering with the air into the engine cylinders most intensively affects the first piston ring, the piston and the upper part of the cylinder.

The influence of the parameters of the dust sucked in together with the air to the engine on the value of wear is considered in relation to the wear of these very engine elements. The value of their wear is determined mainly during experimental research on real engines. Due to great difficulties in carrying out such tests, the available literature contains few and partial results, mainly concerning the influence of three dust parameters (grain size, dust concentration in the air, and grain hardness) on the accelerated wear of the first piston ring, piston, top part of the cylinder, and main and connecting-rod journals.

The effect of particle size on engine wear is a complex process. Particles whose diameter is smaller than the thickness of the oil film should not damage the surface. However, they weaken the oil film and can cause an increase in oil density.

The magnitude of dust-induced wear of engine components depends on the properties of the dust drawn in with the air, and mainly on [93]:

- The size of the dust grains;

- Dust concentration in the air;

- Granulometric and chemical (hardness) composition of dust;

- $\quad$ Shape of dust grains.

At the same time, the effect of dust is closely related to:

- $\quad$ Clearance values between mating parts;

- $\quad$ Engine design parameters (compression ratio, piston stroke);

- $\quad$ Presence and type of lubricating oil;

- $\quad$ Engine operating parameters (load, rotational speed);

- Mechanical properties of the materials from which the components are made);

- Frequency of air filter maintenance.

The author of the paper [94] shows that there is a close relationship between the dimensions of $\mathrm{SiO}_{2}$ grains in the air sucked into the engine and the amount of wear of the cylinder liner and piston. All dust grains above $1 \mathrm{~m}$ cause increased wear, but the greatest abrasive effect occurs at grain sizes of 7-18 $\mu \mathrm{m}$-Figure $8 \mathrm{a}$. 


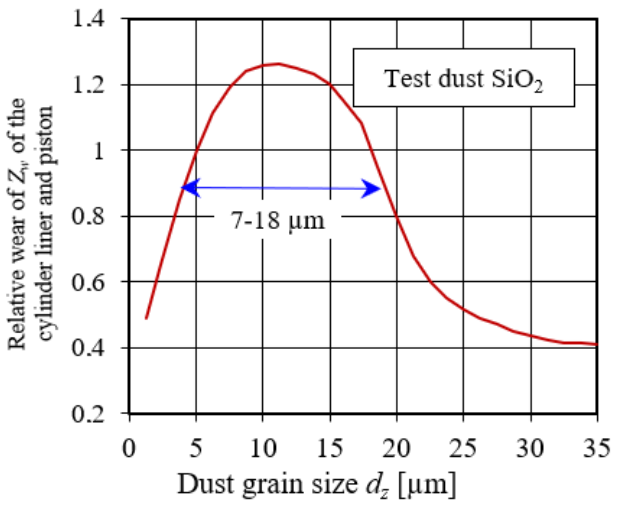

(a)

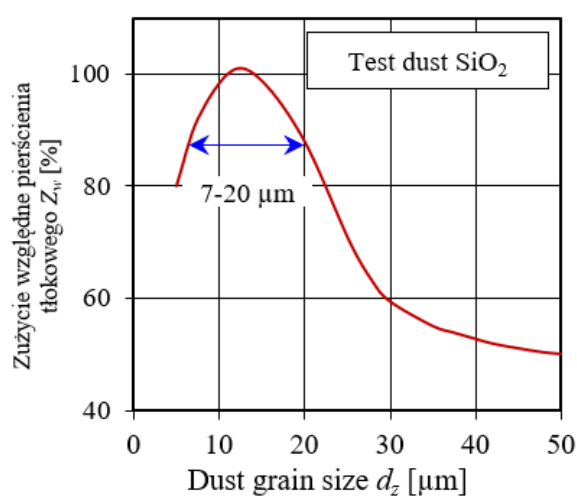

(b)

Figure 8. Effect of $\mathrm{SiO}_{2}$ dust grain size on relative wear of: (a) cylinder liner and piston [94], (b) piston ring. Figure made by the authors using data from [95].

A similar nature of wear, in this case of the upper piston ring of a Diesel engine, is shown in the graph in Figure $8 \mathrm{~b}$. The greatest abrasive effect of this ring was found for grains in the 7-20 $\mu \mathrm{m}$ range [95]. The same wear value is caused by dust grains of small (less than $5 \mu \mathrm{m}$ ) as well as large sizes-above $20 \mu \mathrm{m}$.

The graph shown in Figure 9 confirms, the relationship between particle size and component wear. Five classified fractions of road dust were used in the study. The maximum effect of piston ring wear was obtained for particles of $21.5 \mu \mathrm{m}$ diameter. Above and below this size, ring wear is significantly reduced.

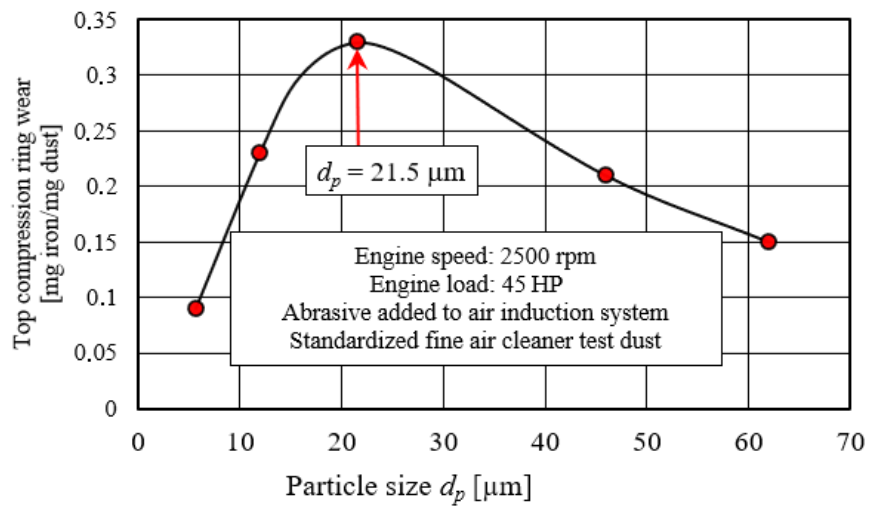

Figure 9. Influence of the road dust grain size on the relative wear of the upper piston ring. Figure made by the authors using data from [96].

This phenomenon is explained by the fact that dust grains of large size do not penetrate between two mating surfaces at the first moment and do not cause wear. However, due to the variation of operating conditions and engine load, the oil film thickness is constantly changing. In such a situation, large dust grains can penetrate between two moving parts and when they come into contact with two surfaces they crumble into smaller grains and only then do they cause wear.

This phenomenon is confirmed by the graphs in Figure 10. The greatest wear of the cylinder face of the ZS engine was caused by quartz (silica) dust grains with sizes of $20-40 \mu \mathrm{m}$. Dust grains with dimensions in the range $d_{p}=0-4 \mu \mathrm{m}$ cause the same value of wear as grains with dimensions $d_{p}=40-60 \mu \mathrm{m}$ [97]. Regardless of the size of the dust grains, the maximum wear occurred in the upper part of the cylinder liner, which is typical for P-PR-CL association, and this is due to the fact that at this location the upper piston ring reaches the TDC position. It is known from the kinematics of the piston-crank system 
that near TDC and BDC the piston ring travel velocity along the cylinder liner surface has the smallest value, and at TDC and BDC it is zero. The lubrication wedge disappears, and then even the smallest dust grains come into contact with the mating surfaces, causing their abrasive wear.

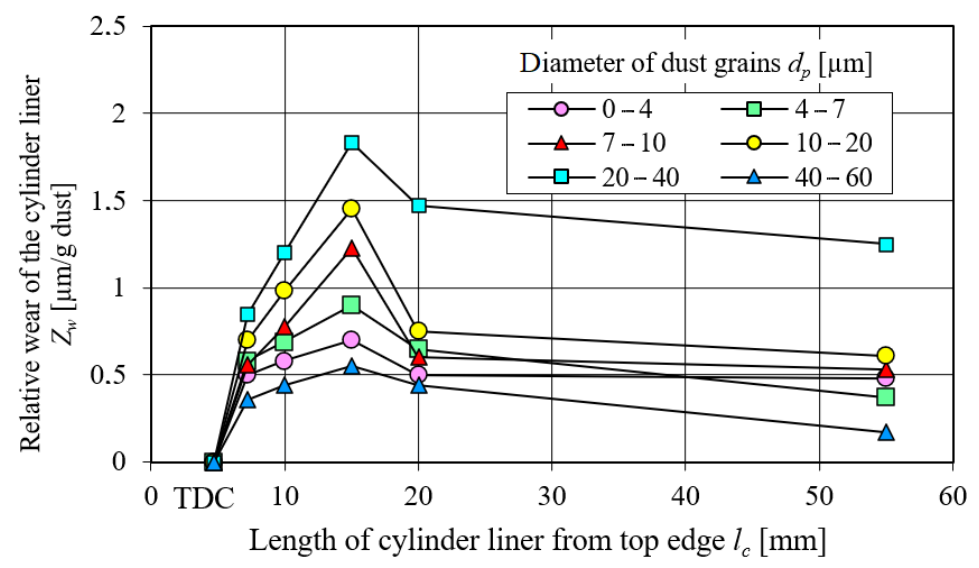

Figure 10. Cylinder face wear for different test dust fractions. Figure made by the authors using data from [97].

According to the author of the paper [98], the highest value of piston ring wear (241 mg/h) was observed for the dust fraction 5-10 $\mu \mathrm{m}$, and the lowest wear $(5 \mathrm{mg} / \mathrm{h})$ was caused (as expected) by dust grains with sizes of $0-5 \mu \mathrm{m}$. The wear value with dust grains of size 10-20 $\mu \mathrm{m}$ and standard "fine" dust $0-80 \mu \mathrm{m}$ is $50 \%$ less than the wear for the dust fraction 5-10 $\mu \mathrm{m}$ (Figure 11). A dust concentration of 1.0 grain/1000 cubic feet of air $\left(28.317 \mathrm{~m}^{3}\right)$ was used.

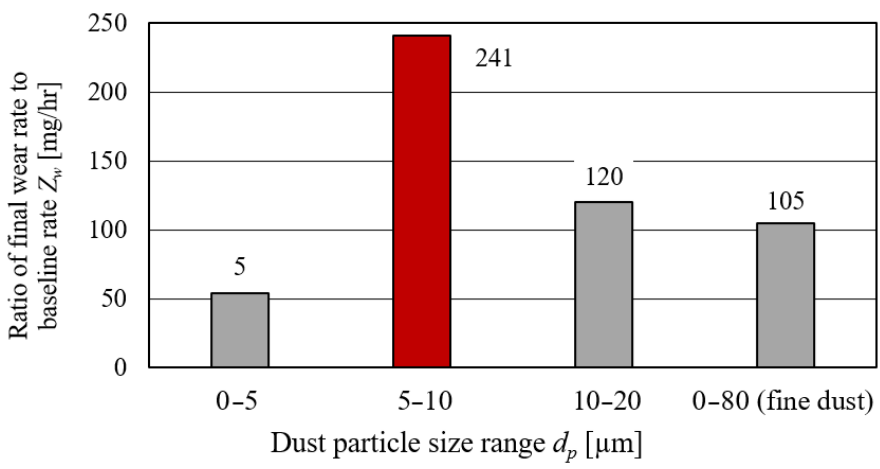

Figure 11. Influence of dust grain size on piston ring wear. Figure made by the authors using data from [98].

From the data presented in Figure 12, it can be seen that the highest values of the wear rate of the main and connecting-rod journal surfaces of a Diesel engine are caused by dust grains with sizes of $5-10 \mu \mathrm{m}$, while dust grains with sizes of $0-5 \mu \mathrm{m}$ are the cause of increased wear of the piston rings of this engine [85]. Even contaminants containing large particles up to $80 \mu \mathrm{m}$ did not cause as much damage as contaminants with particles concentrated in the size range of 0 to $10 \mu \mathrm{m}$.

Studies by the authors of the work [100] have shown that dust with a grain size of 0-5 $\mu \mathrm{m}$ causes more engine wear than grains in the $0-40 \mu \mathrm{m}$ range. Similar trends were observed by the authors of the work [85], who showed that about four times more wear of diesel engine rings is caused by dust grains with grain sizes of $0-5$ and $5-10 \mu \mathrm{m}$ than by particles of 10-20 $\mu \mathrm{m}$. According to another study [101], engine wear is an exponential function of particle diameter in the $2-20 \mu \mathrm{m}$ range, and wear caused by $4-10 \mu \mathrm{m}$ particles 
is about three times greater than for $2-4 \mu \mathrm{m}$ particles. The obvious inconsistency in the size of particles causing maximum engine wear may be due to the use of different engines with different dynamic clearances between moving parts and different measurement techniques.

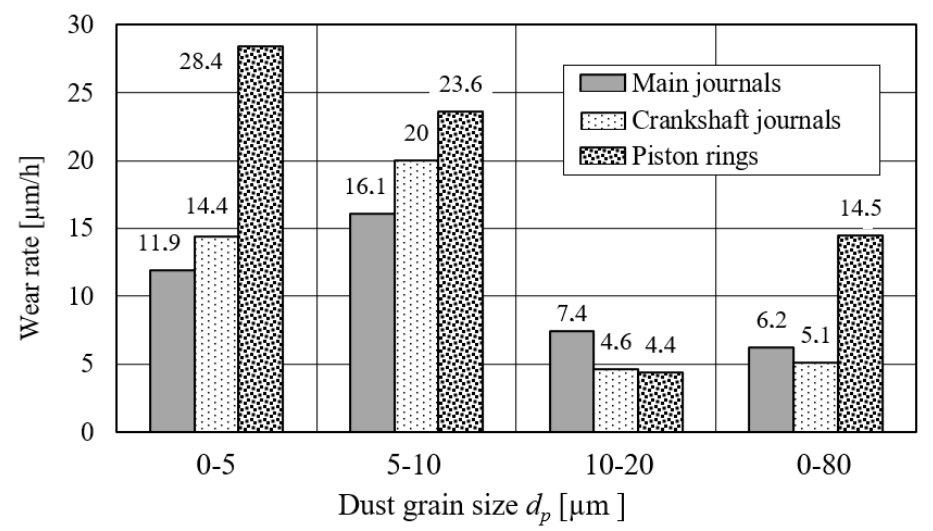

Figure 12. Effect of dust grain size on wear rate of Diesel engine components. Figure made by the authors using data from $[85,99]$.

Tests performed by the authors of the paper [102] showed that the main bearing, crankshaft bearing and oil ring experienced maximum wear by a different range of particle sizes. During the tests, a sample of $2 \mathrm{~g}$ of AC Coarse test dust with particle size ranges of $0-5,5-10,10-20,20-40,40-80$, and $80-200 \mu \mathrm{m}$ was introduced into the engine lubrication system (without filters). For the oil ring, the maximum wear was caused by particle sizes of 5-10 $\mu \mathrm{m}$, for the main bearing it was particles in the 20-40 $\mu \mathrm{m}$ range, and for the connecting rod bearing the most dangerous particles were 20-80 $\mu \mathrm{m}$ (Figure 13). This sensitivity to different particle sizes can be explained by the fact that each of these associations has a different clearance between the mating surfaces.

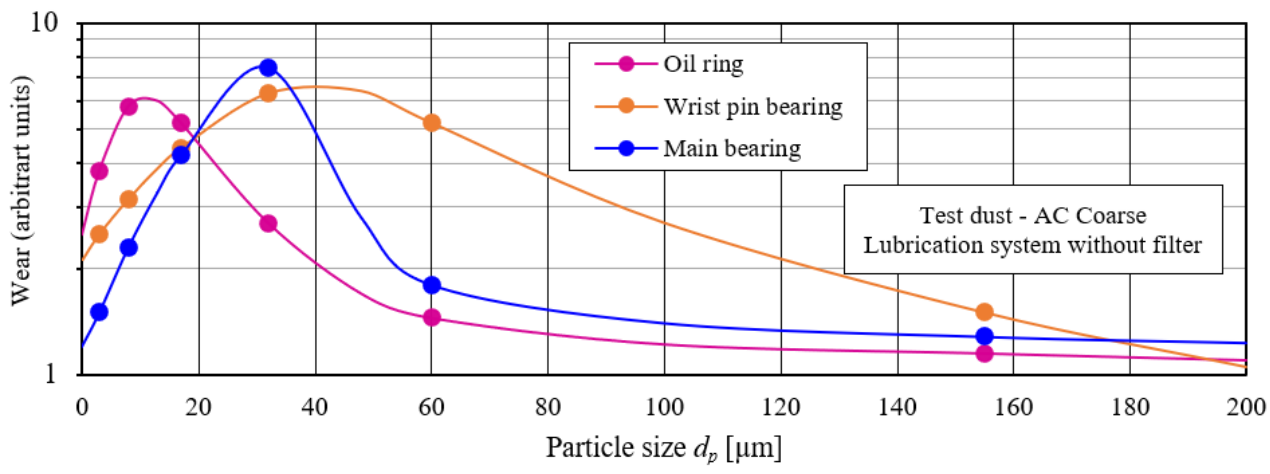

Figure 13. The particle wear sensitivity functions for the main bearing, wrist pin bearing, and oil ring. Figure made by the authors based on data from [102].

It can be seen from the graphs in Figure 14 that as the particle radius $R$ increases, the wear rate of the engine cylinder liner and piston ring increases rapidly, but only up to a certain critical size, in this case about $7 \mu \mathrm{m}$, and then the wear rate decreases and is almost constant. This may be related to the fact that the clearance between the piston ring and the cylinder liner is small enough to limit the entry of larger size particles and thus eliminate their effect on wear. Moreover, Figure 14 shows that the wear of the piston ring is almost ten times greater than that of the cylinder liner, even though both components are affected by the same value of dust concentration in the air [103]. 


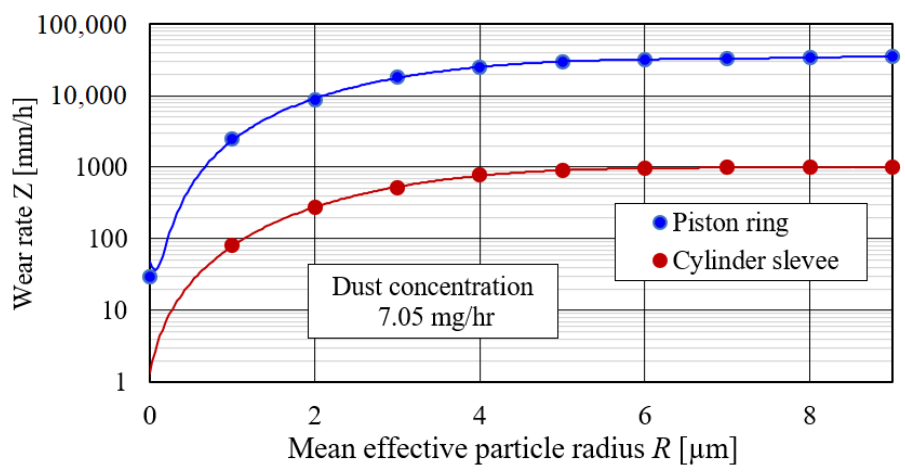

Figure 14. Effect of particle size on wear rate of cylinder liner and piston ring. Figure made by the authors using data from [103].

From the data in Figure 15, it can be seen that the engine load has a significant effect on the abrasive wear of the upper seal ring. Changing the engine load from 0-20 HP causes a slight increase in ring wear. An increase in load above $22.5 \mathrm{HP}$ results in a more than fourfold increase in wear intensity, which may be due to a decrease in oil film thickness between the friction surfaces and the occurrence of grain contact with the friction surfaces [96].

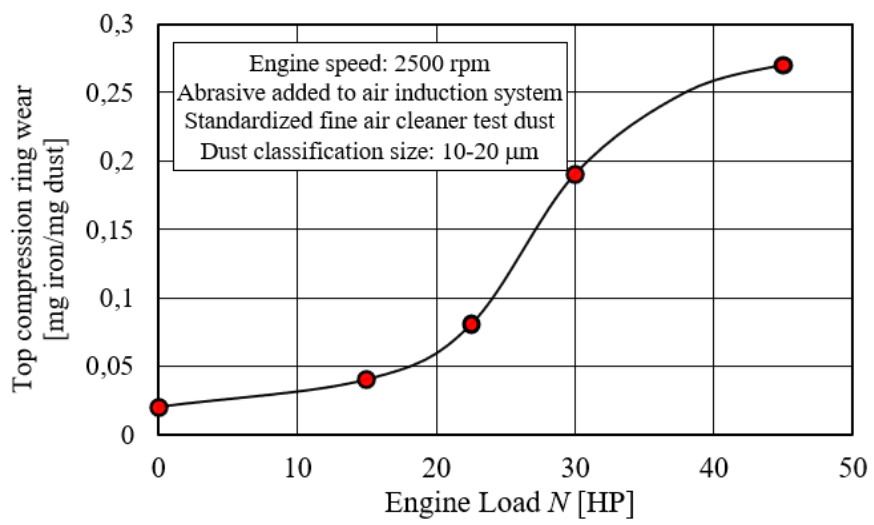

Figure 15. Effect of engine load on top seal ring wear due to $10-20 \mu \mathrm{m}$ of dust. Figure made by the authors using data from [96].

Figure 16 shows, for different operating times of the friction pair, the effect of dust particle size on the bearing wear rate [82]. Tests were carried out without filter and with the addition of $0.4 \mathrm{~g}$ of road dust in the indicated particle size ranges. For the first half hour after dust addition, the fraction in the 10-20 $\mu \mathrm{m}$ range caused bearing wear of $k_{w}=124.8 \mathrm{mg} / \mathrm{h}$. This is significantly greater than the bearing wear caused by the other fractions, and also greater wear caused by the same mass of test dust in the $0-80 \mu \mathrm{m}$ range. During the next $30 \mathrm{~min}$ after dust addition, the rate of bearing wear by all fractions is almost identical and takes values around $k_{w}=14 \mathrm{mg} / \mathrm{h}$. These values are similar to the values of bearing wear by the $0-5 \mu \mathrm{m}$ fraction for the first half hour after dust addition. After the third hour of friction pair operation, a slight wear rate was recorded, but only for test dust in the 0-80 $\mu \mathrm{m}$ range. The authors believe that large dust particles are crushed into smaller ones by the action of the oil pump and between the surfaces of engine components.

The paper [104] presents the results of a study on the effect of three granulations of quartz dust: $2.5-7,8-20$, and $16-40 \mu \mathrm{m}$ contained in oil on the wear of engine plain bearings. The highest wear of plain bearings is caused by quartz dust particles contained in oil with size up to $20 \mu \mathrm{m}$. 


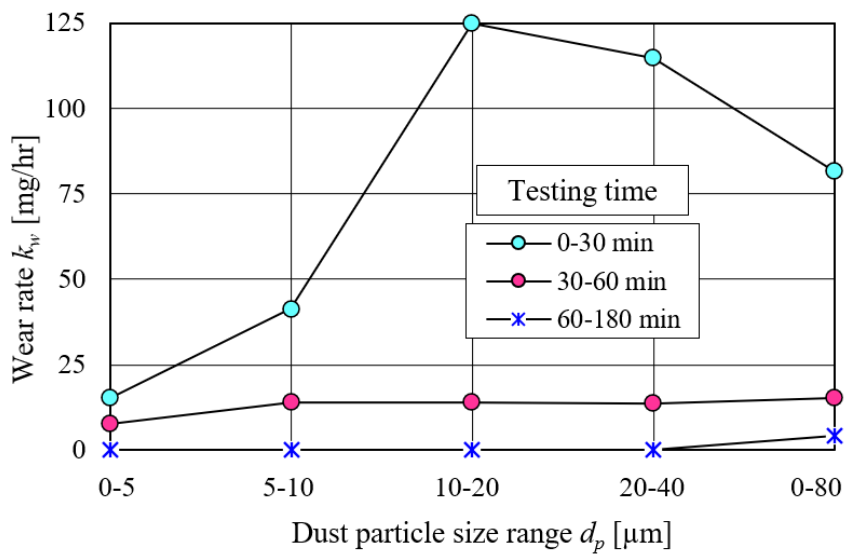

Figure 16. Effect of particle size of different dust fractions on wear rate for different bearing running time. Figure made by the authors based on data from. Figure made by the authors using data from [82].

It can be seen from the graphs presented in Figure 17 that during engine operation at $50 \%$ load, as the size of dust grains increases in the range of $2.5-22.5 \mu \mathrm{m}$, the wear of cylinder liners increases almost linearly regardless of the type of dust [86]. Dust grain sizes of 2.5-7.5 $\mu \mathrm{m}$ and engine operation at $100 \%$ load cause 3.5 times more bushing wear than during engine operation at $50 \%$ load.

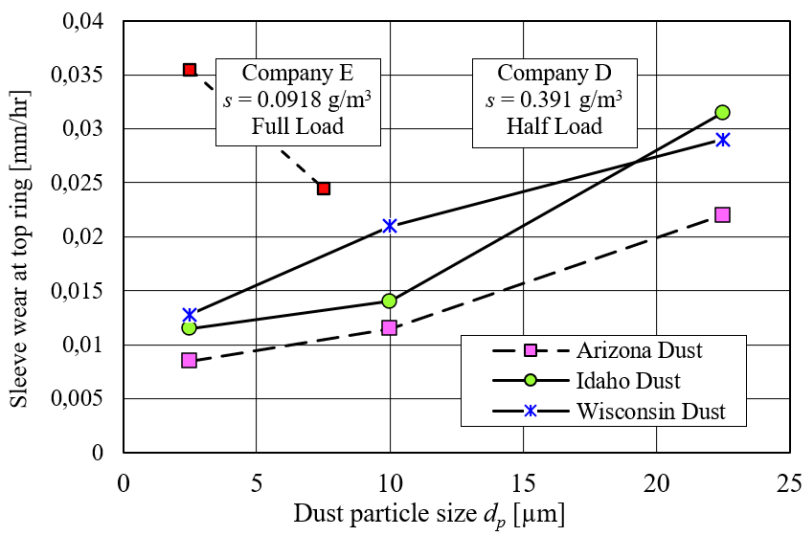

Figure 17. Effect of grain sizes of different dusts on the intensity of cylinder liner wear at the height of the upper piston ring and. Figure made by the authors using data from [105].

The abrasive wear of engine component surfaces is directly related to the hardness of the particles. The hard dust grains are silica $\mathrm{SiO}_{2}$ and alumina $\mathrm{Al}_{2} \mathrm{O}_{3}$, whose hardness, judged by the Mohs 10-point scale (diamond has a value of 10 and talc has a value of 1), takes on a value of 7 and 9, respectively. The hardness of both dust components far exceeds that of most engine construction materials. The hardness of hardened carbon steel is about 6.5 on the Mohs scale.

The effect of the hardness of the dust grains on the wear of the upper piston ring is shown in Figure 18. In the case of diamond dust, the wear is much higher than in the case of road dust of equivalent grain size, and unlike road dust, whose primary component is $\mathrm{SiO}_{2}$, it steadily increases with particle size over the entire range studied.

Lower hardness dust causes accelerated wear when the abrasive comes into contact with the surface, then the dust grains are smoothed and ground. Wear is then limited to the first piston ring. On the other hand, dust of high hardness does not undergo the process of grinding and comminution, but causes wear of all piston rings and then, after getting into oil, it takes part in the process of accelerated wear of other friction pairs (main journal- 
crankcase, connecting rod-crankcase, camshaft journal-crankcase, valve stem-guide, valve cam-cam, and turbocharger bearings), which are reached by engine oil.

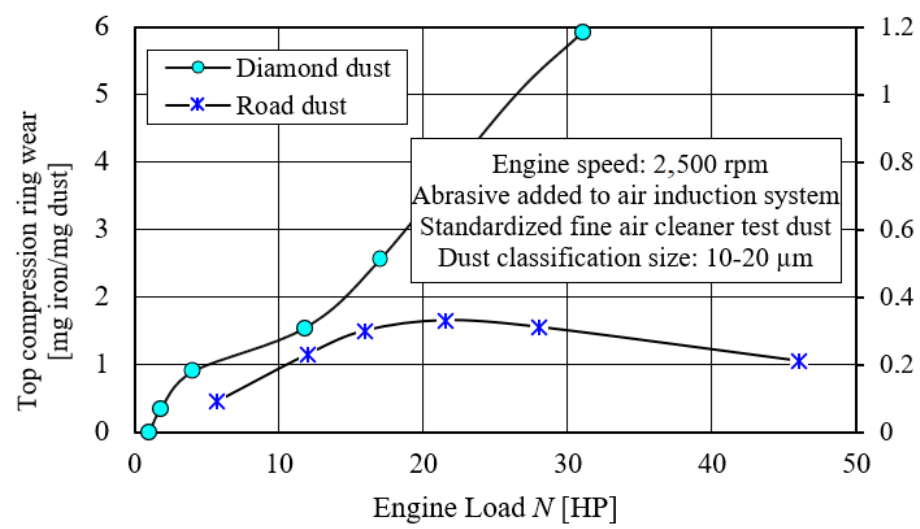

Figure 18. Effect of dust grain size with different hardness on upper piston ring wear. Figure made by the authors using data from [96].

The effect of the size of dust grains of different hardness (corundum and quartz) on the wear of a chrome plated piston ring and cylinder liner is shown in Figure 19. The course of the ring and liner wear rate for both minerals is practically the same. It can be seen from Figure 19 that $\mathrm{Al}_{2} \mathrm{O}_{3}$ particles with a diameter in the range of $0-10 \mu \mathrm{m}$ caused several times more wear than $\mathrm{SiO}_{2}$ particles of the same size and hardness (6-7) on the Mohs scale [105]. The ring wear caused by $\mathrm{SiO}_{2}$ is four times less than $\mathrm{Al}_{2} \mathrm{O}_{3}$. For particles up to $5 \mathrm{~mm}$ in size, the wear intensity is higher than for particles of larger size. This may be due to the fact that at the given friction conditions a certain part of particles larger than $5 \mu \mathrm{m}$ does not enter the tribological areas of rings and sleeves and does not participate in abrasive wear.

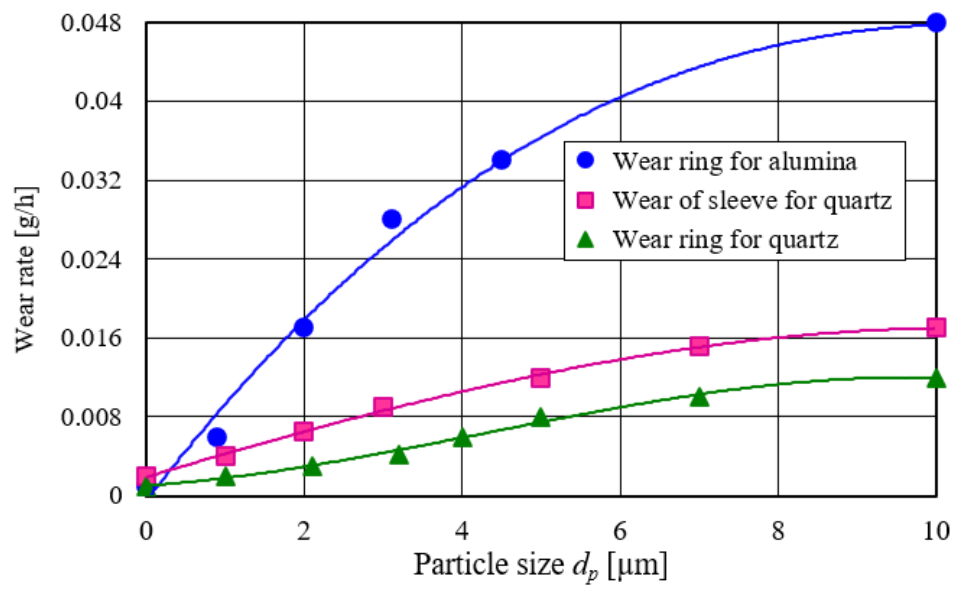

Figure 19. Effect of dust grain size of different hardness on wear of chrome plated piston ring and cylinder liner. Figure made by the authors using data from [105].

The concentration of dust in the air is another factor intensifying the wear of engine components. The life of an engine is characterized by varying values of air dustiness. For an air filter with a certain filtration efficiency, a higher dust concentration in the air results in a greater mass of dust entering the engine cylinders. Several studies have shown that engine wear increases significantly as the concentration of dust taken in with the air by the engine increases [94,96,103,106-108].

The author of the paper [106] presented data on the concentration of dust in the air depending on the conditions of vehicle use (Table 1) and then related it to the wear rate of engine components-Figure 20. 
Table 1. Dust concentration values as a function of vehicle operating conditions Data for the table were taken from the paper [106].

\begin{tabular}{cc}
\hline Condition & Dust Concentration $\boldsymbol{s}\left(\mathbf{m g} / \mathbf{m}^{3}\right)$ \\
\hline Average Ambient & $0.010-0.139$ \\
\hline 95th Percentile Ambient & 0.089 \\
\hline 99th Percentile Ambient & 0.112 \\
\hline Paved Roads & $0.139-57$ \\
\hline Dirt Roads & $0.139-6113$ \\
\hline Dust Storms & $0.1-176$ \\
\hline Worst Dust Storm & 3000 \\
\hline 0 Visibility & 883 \\
\hline $20 \times 0$ Visibility & 17,657 \\
\hline
\end{tabular}

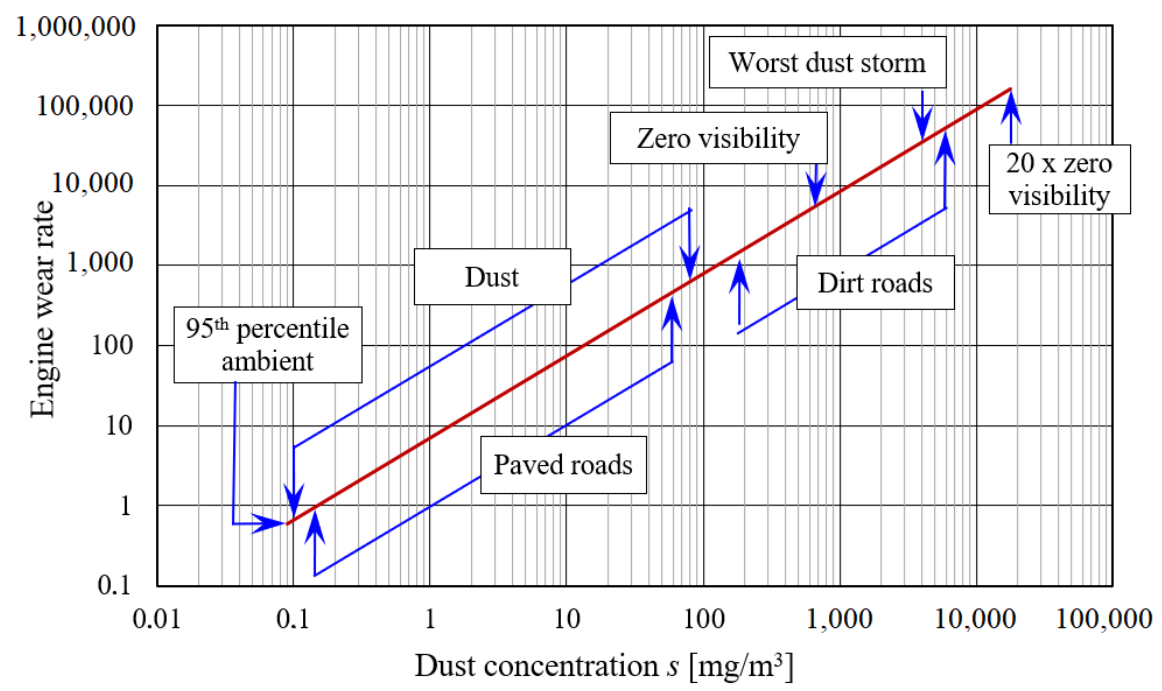

Figure 20. Effect of dust concentration versus vehicle operating conditions on engine wear rate. Figure made by the authors using data from [106].

The established linear relationship between engine wear and dust concentration shows that when the dust concentration in the environment increases by more than 5 orders of magnitude, the intensity of engine wear also increases by the same amount. An engine operating on a dirt road or in a gravel pit in zero visibility, wears out about 10,000 times faster than an identical engine operating in a rural environment (Figure 20).

Similarly, the author of the paper [96] showed that in the range of dust concentration in the inlet air from 0.0042 to $0.287 \mathrm{~g} / 1000 \mathrm{~m}^{3}$ of air, the wear rate of the upper piston ring is a linear relationship (Figure 21).

During testing, standard engine operating conditions were maintained so as to minimize piston ring wear from causes other than abrasion. The test dust used was Arizona fine road dust also called "Standardized fine air cleaner test dust" with typical chemical analysis shown in Table 2 and granulometric composition Table 3 [96].

According to the author of the paper [107], the engine wear, depending on the concentration of dust in the air increases exponentially. At the dust concentration $s=20-30 \mathrm{mg} / \mathrm{m}^{3}$ the wear becomes 1000 times higher than at the concentration $s=1-2 \mathrm{mg} / \mathrm{m}^{3}$, which is 10 times lower.

Figure 22 shows the exponential relationship between the Csepel Diesel engine life and the airborne dust concentration (mass of $\mathrm{SiO}_{2}$ dust drawn in with the air) of 10-15 $\mu \mathrm{m}$ [94] 


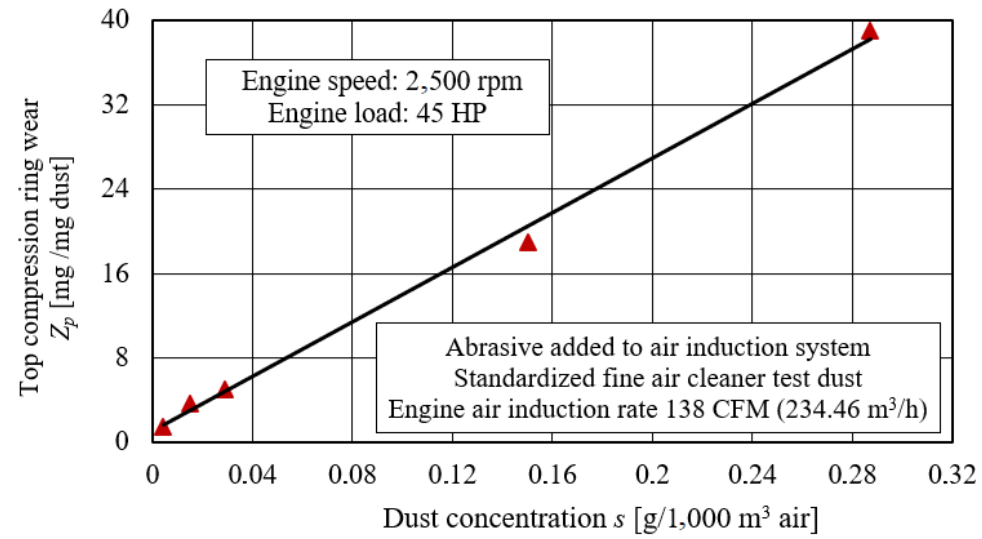

Figure 21. Effect of dust concentration on upper piston ring wear. Figure made by the authors using data from [96].

Table 2. Chemical analysis of fine grade Arizona Road dust used in abrasive wear tests [96].

\begin{tabular}{cc}
\hline Components of Dust & Percent by Weight [\%] \\
\hline $\mathrm{SiO}_{2}$ & $67-69$ \\
\hline $\mathrm{Fe}_{2} \mathrm{O}_{3}$ & $3-5$ \\
\hline $\mathrm{Al}_{2} \mathrm{O}_{3}$ & $15-17$ \\
\hline $\mathrm{CaO}$ & $2-4$ \\
\hline $\mathrm{MgO}$ & $0.5-1.5$ \\
\hline Total Alkalis & $3-5$ \\
\hline Ignition loss & $2-3$ \\
\hline
\end{tabular}

Table 3. Particle size distribution of dust used in abrasive tests [96].

\begin{tabular}{cc}
\hline Dust Particle Sizes $\boldsymbol{d}_{\boldsymbol{p}}[\boldsymbol{\mu \mathrm { m } ]}$ & Mass Fraction of Grains in the Dust $\boldsymbol{F}_{\boldsymbol{m}}[\boldsymbol{\%}]$ \\
\hline $0 \div 5$ & $39 \pm 2$ \\
\hline $5 \div 10$ & $18 \pm 3$ \\
\hline $10 \div 20$ & $16 \pm 3$ \\
\hline $20 \div 40$ & $18 \pm 3$ \\
\hline $40 \div 80$ & $9 \pm 3$ \\
\hline
\end{tabular}

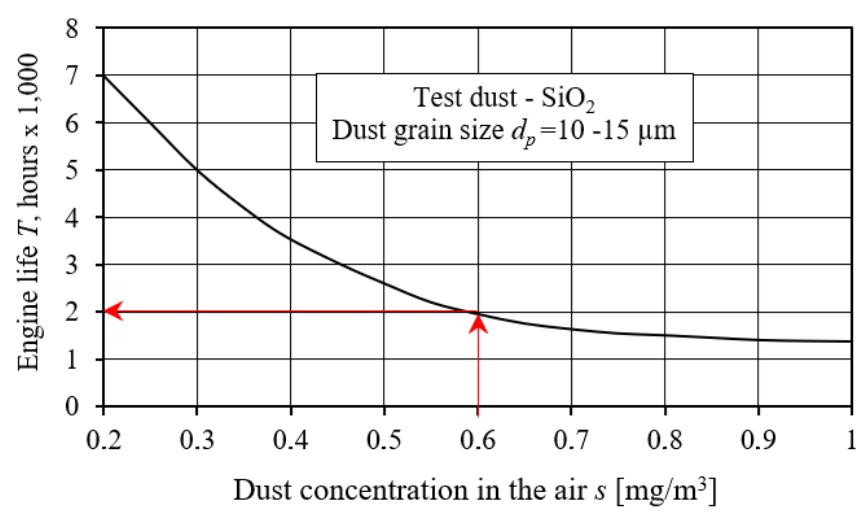

Figure 22. Dependence of engine life on dust concentration in air. Figure made by the authors using data from [94]. 
From the graph in Figure 22, it can be seen that if the engine draws in ambient air with a dust concentration of $0.2 \mathrm{mg} / \mathrm{m}^{3}$, the engine life (understood here as the number of kilometers driven by the vehicle or hours of engine operation up to a certain wear limit) is $7000 \mathrm{~h}$. If the mass of aspirated dust increases three times, the life of the engine decreases to approximately $2000 \mathrm{~h}$. An increase in the dust concentration in the air from 0.2 to $1 \mathrm{mg} / \mathrm{m}^{3}$ results in a fivefold increase in the mass of dust supplied to the engine cylinders and a sixfold decrease in engine life.

The relationship between Diesel engine life and the amount of dust in the air (dust concentration) and air filter permeability is shown in Figure 23 [94]. The increase in the coefficient $\varepsilon$ of air filter permeability (decrease in filtration efficiency) decreases the engine life the more the dust concentration in the air has a higher value.

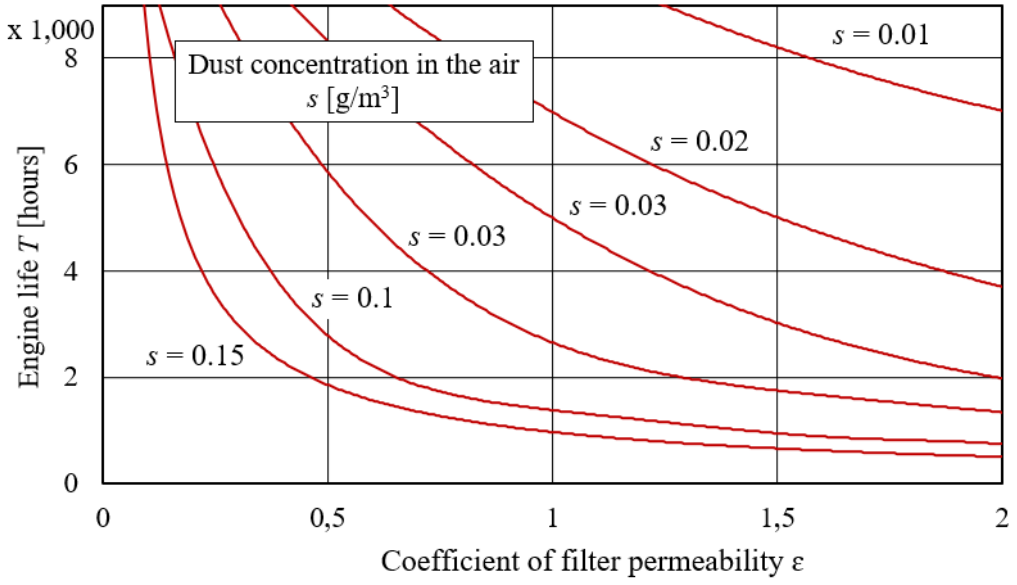

Figure 23. Dependence of engine life on coefficient of filter permeability $\varepsilon$ for different dust concentrations in the air. Figure made by the authors using data from [94].

According to the authors of the work [108], a fourfold increase in the concentration of quartz dust in the intake air causes a fourfold increase in the intensity of wear of the first piston ring of the D-54A engine, regardless of the size of the dust grains (Figure 24).

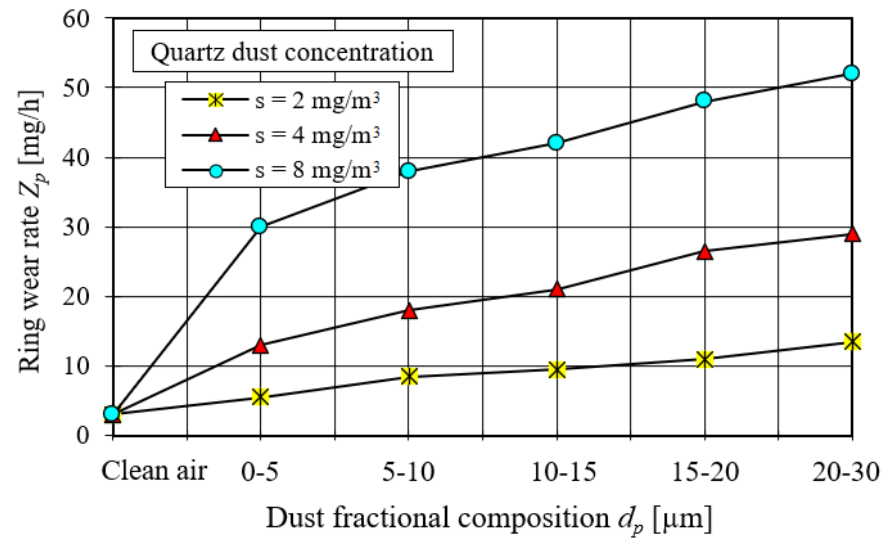

Figure 24. Wear intensity of the first piston ring of the D-54A engine for different values of quartz dust concentration in the intake air and different fractional compositions. Figure made by the authors using data from [108].

Figure 25 shows the effect of particle size and dust concentration on piston ring and cylinder liner wear for two cases. In the first case, the dust particle size is reduced by $50 \%$ from the reference value and is $3.4 \mu \mathrm{m}$, and in the second case, the dust concentration per engine cylinder is reduced by $50 \%$ from the reference value and is $3.525 \mathrm{mg} /$ cylinder. 
A 50\% reduction in particle size or dust concentration reduces the wear rate of both the cylinder liner and piston ring compared to the reference wear by $40 \%$ and $50 \%$, respectively (Figure 25). Thus, reducing the amount of dust per engine cylinder has a greater effect on the wear rate compared to reducing the particle size.

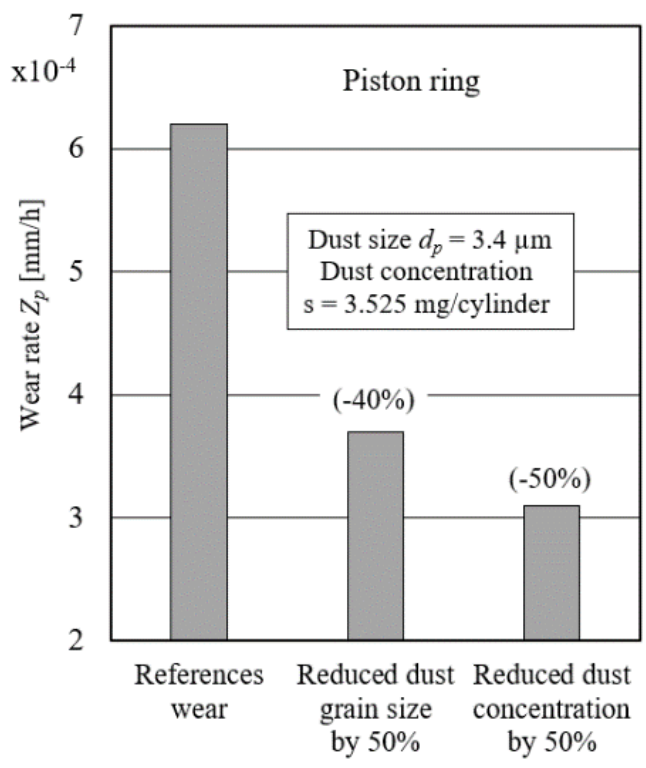

(a)

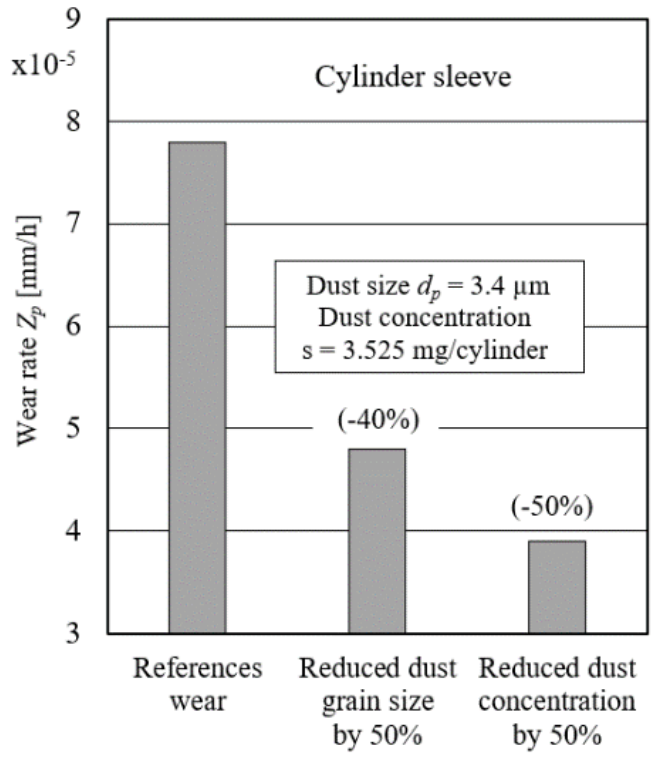

(b)

Figure 25. Wear rate: (a) piston ring, (b) cylinder liner for 50\% reduction in dust particle size (case 1) and $50 \%$ reduction in dust concentration per cylinder (case 2). Figure made by the authors using data from [103].

However, both factors have a significant effect on the wear rate of the piston ring and cylinder liner and are interrelated. Therefore, it is important to use air filters with high filtration efficiency and accuracy, which can reduce the influence of both factors especially during the operation of vehicles in dusty conditions, and thus ensure longer engine life.

Figure 26 shows the abrasive wear rate of the cylinder liner and piston ring when three air filters with different filtration efficiencies are used compared to when no air filter is installed in the engine.

It can be seen that installing inlet air filters for the engine significantly reduces the wear rate of its components. For example, a filter with $97.8 \%$ filtration efficiency reduces the abrasive wear of the cylinder liner from $107 \times 10^{-5}$ to $2.02 \times 10^{-5} \mu \mathrm{m} / \mathrm{h}$, i.e., by almost $98 \%$. Any air filter with higher efficiency definitely reduces the wear of both engine components, with the wear rate of piston rings being several times higher than that of the cylinder liner.

Assuming the abrasive wear of both the cylinder liner and piston ring without air filter as $100 \%$ (Figure 26), the use of an air filter with $97.8 \%$ efficiency reduces the wear of both elements to $1.89 \%$. After using an air filter with higher efficiency $(99.45 \%)$, the wear of the cylinder liner and piston ring is only $0.41 \%$ compared to the wear when there was no air filter in the engine.

An increase in the engine oil filtration efficiency from $\varphi_{1}=66.7 \%$ to $\varphi_{2}=95 \%$ results in a more than $50 \%$ decrease in the wear rate of the piston rings of the loaded Diesel engine-Figure 27 [109].

Figure 28 shows the dependence of piston ring wear magnitude on slip velocity for different ring loads at 24-h tests. As the slip velocity increases, the ring wear increases the higher the load. In contrast, Figure $28 \mathrm{~b}$ shows the dependence of ring wear on load for 24-h test runs at $150{ }^{\circ} \mathrm{C}$ and for two different slip speeds. Both at slip speeds of 1 and $4 \mathrm{~m} / \mathrm{s}$ the 
wear increases almost proportionally to the ring load, with the higher speed having higher wear values.

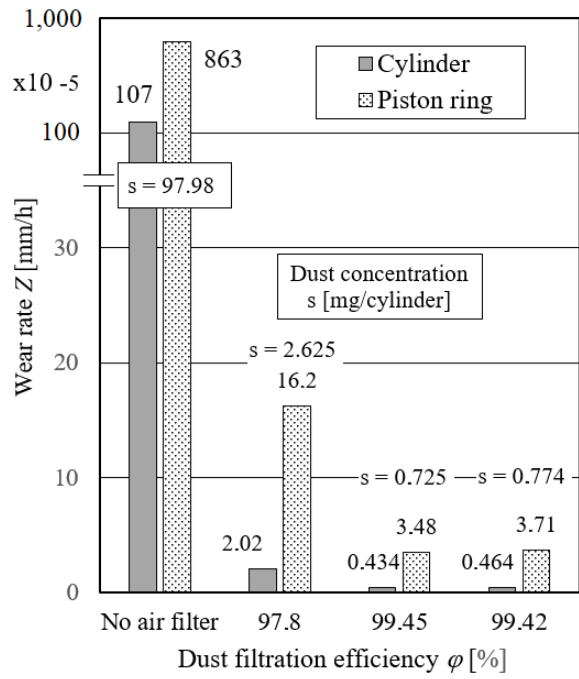

(a)

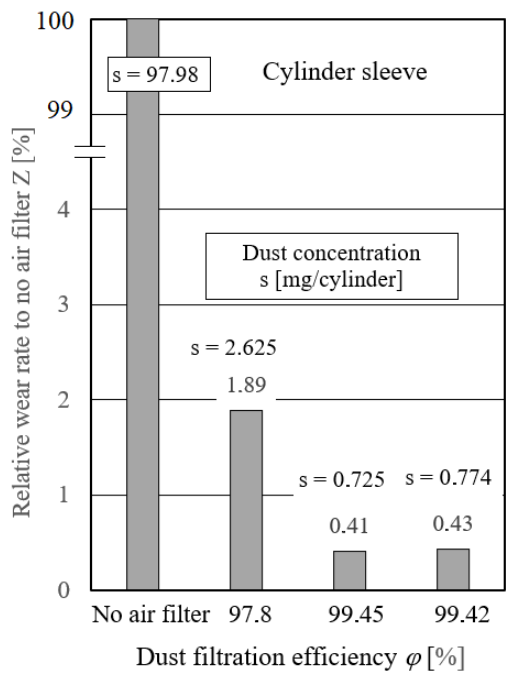

(b)

Figure 26. Effect of air filter efficiency on: (a) wear rate of cylinder liner and piston rings, (b) relative wear rate of both compared to no air filter. Figure made by the authors using data from [103].

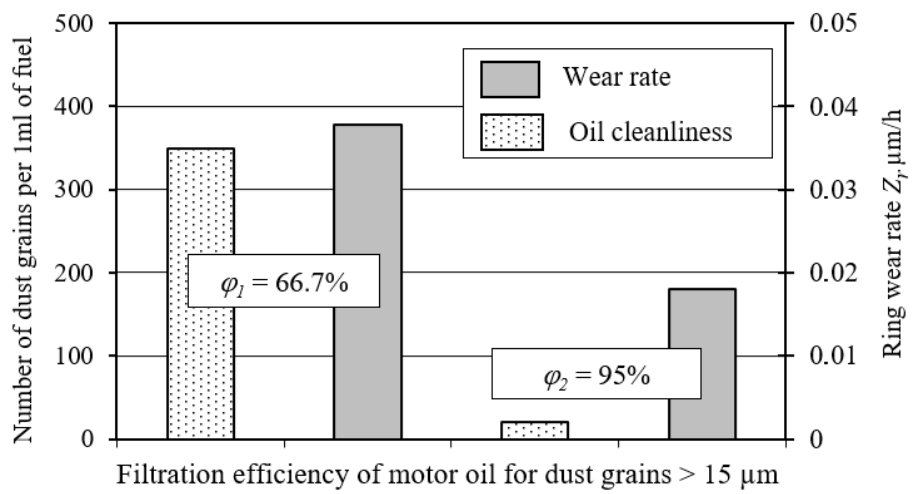

Figure 27. Effect of filtration efficiency of dust grains larger than $15 \mu \mathrm{m}$ contained in engine oil on the wear rate of piston rings of a Diesel engine. Figure made by the authors using data from [109].

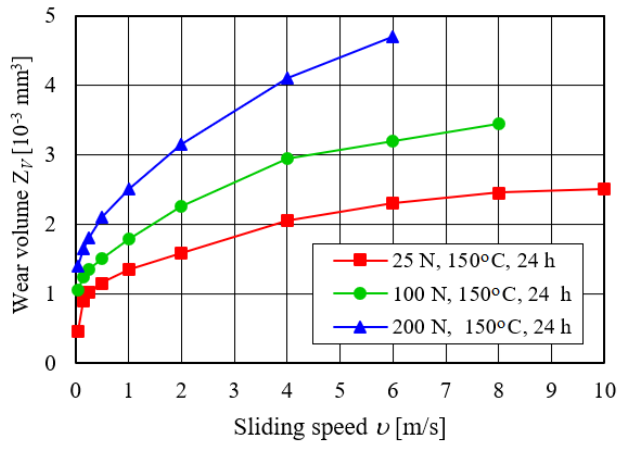

(a)

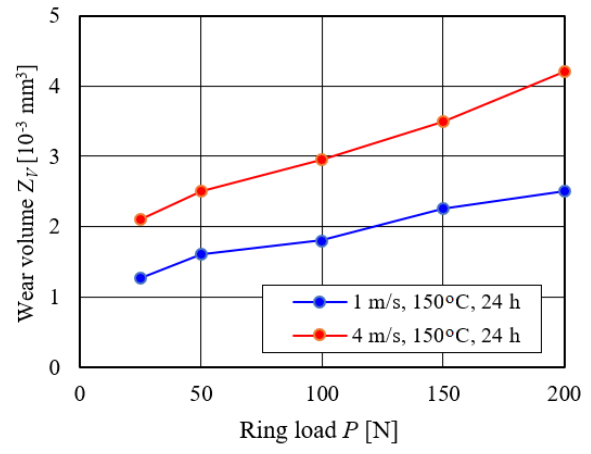

(b)

Figure 28. Ring wear as a function of: (a) slip rate at 24-h test time, average temperature $150{ }^{\circ} \mathrm{C}$, and ring load of 25, 100, and $200 \mathrm{~N},(\mathbf{b})$ as a function of load. Figure made by the authors using data from [51]. 
The paper [110] presents an operational study of the wear of the piston-cylinder group of a Jamz $242 \mathrm{~N}$ truck engine. The vehicles were operated on unpaved roads while transporting iron ore. The engines were equipped with two different air filters. The wear of the piston-cylinder group of the engine with the paper cartridge filter was $50 \%$ lower than when the engine was equipped with the inertia-wash filter, which had a lower filtration efficiency. The cylinder liner wear intensity at TDC (at the level of the first piston ring) had an average value of 1.6 and $3 \mu \mathrm{m} / 1000 \mathrm{~km}$, respectively (Figure 29). When these cars were used on asphalt roads, the wear intensity of the piston-cylinder group elements decreased six times [110].
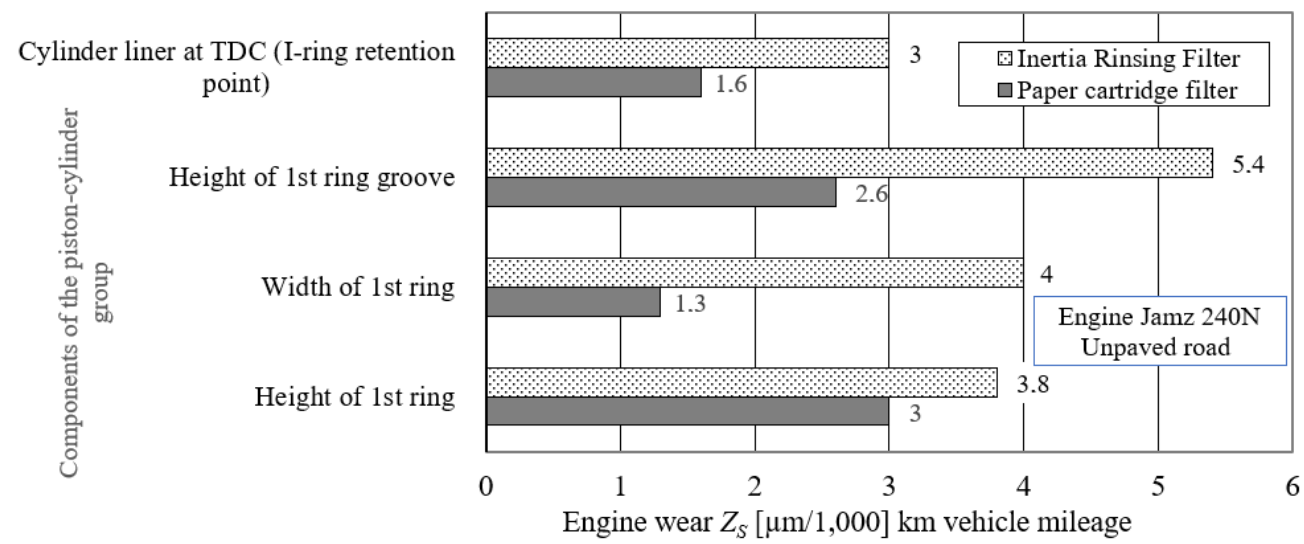

Figure 29. Wear of engine piston-cylinder group components during use on an unpaved road. Figure made by the authors using data from [110].

The results of piston ring wear tests are presented in [45]. The test object was a 4-cylinder turbocharged compression ignition engine with a displacement of $1.3 \mathrm{dm}^{3}$, with charge air cooling and exhaust gas recirculation. The engine was equipped with a common rail direct injection system and had a maximum power of $66 \mathrm{~kW}$ at $4000 \mathrm{rpm}$ and a maximum torque of $200 \mathrm{Nm}$ in the range 1750-2250 rpm. The engine had a typical ring arrangement which included a first rectangular sealing ring with a barrel-shaped, chromeplated face, a second conical sealing ring and a double lip scraper ring with chrome-plated faces and with a helical spring. The aluminum piston had a cast iron insert under the first sealing ring and cooling channels.

The tests were conducted during a long-term durability test of the engine operating under heavy load conditions according to a special cycle that was repeated 336 times. The total operating time of the engine during the durability tests was about $1200 \mathrm{~h}$ [45]. The wear of individual piston rings was determined as an increase in ring lock clearance (Figure 30a) and as a decrease in ring height (Figure 30b).

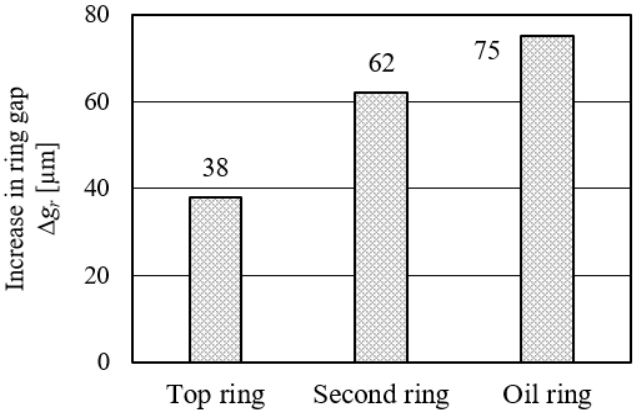

(a)

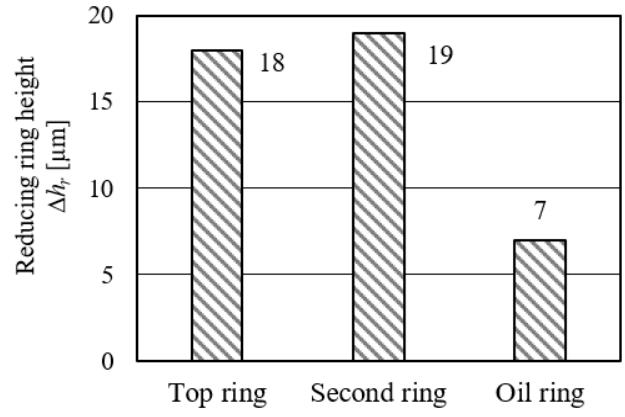

(b)

Figure 30. Piston ring wear during durability test: (a) increase in lock clearance for individual rings, (b) decrease in ring height. Figure made by the authors using data from [45]. 
According to the authors of the paper [111], the intensity of cylinder liner wear at TDC (at the level of the first piston ring) was on average $1.38 \mu \mathrm{m} / 1000 \mathrm{~km}$ of the mileage of a vehicle used in sandy desert conditions and equipped with a two-stage filter (monocyclone paper cartridge) and $3.8 \mu \mathrm{m} / 1000 \mathrm{~km}$ of the mileage for an engine equipped with an inertia-washout filter, i.e., having lower filtration efficiency. The wear of the cylinder liner in the lower part was twice less [111].

The accelerated wear of the cylinder liner, resulting from the operation of a truck engine with a faulty air filtration system, is shown in Figure 31. The abrasive wear of the cylinder liner in the form of parallel continuous bands of scratches along the liner formation, located in the upper zone of the cylinder liner on approximately $1 / 5$ of its circumference, is clearly visible [112]. The scratch bands are so intensive and deep that no traces of the final honing treatment of the cylinder liner surface can be seen. The view of the cylinder face of a truck engine operated with an efficient air filtration system is shown in Figure 31c. There are clear honing marks and combustion product deposits on the cylinder liner above the top dead center of the first piston ring.

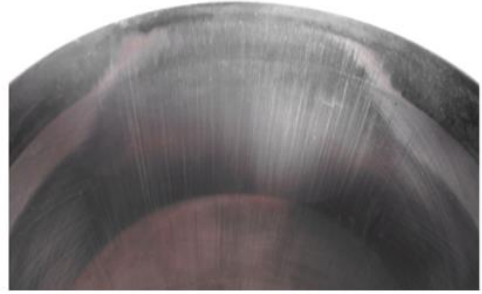

(a)

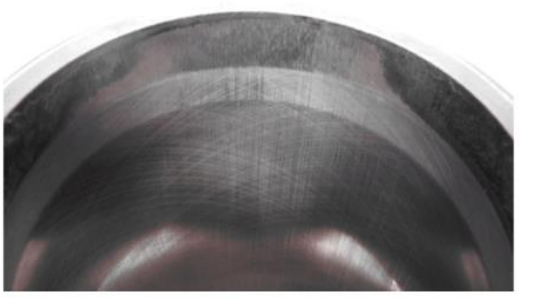

(b)

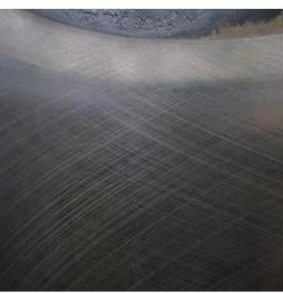

(c)

Figure 31. Wear view of the cylinder liner of a truck engine operated with an inoperative and an operative air filtration system and efficient air filtration system: (a) clear strands of scratches without any honing traces, (b) visible single scratches against the background of surface treatment traces, (c) efficient air filtration system [112].

The loss of material in the form of scratches (grooves) results from the mechanical impact of large-size foreign particles on the surface of the cylinder liner and the hardness is much higher than the hardness of the metallic liner matrix. The cylinder liner has scratches up to $70 \mu \mathrm{m}$ wide (Figure 32). The width of the cracks in the cylinder face is a representation of the size of the foreign particles between the mating parts.

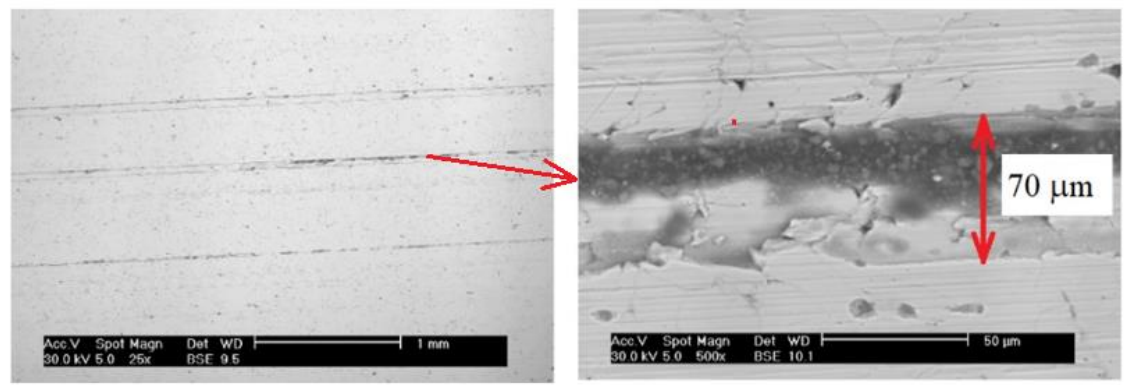

Figure 32. Scratches in the cylinder face caused by foreign particles of high hardness [112].

A paper cartridge newly installed in the filter only after exceeding 20-30\% (Figure 33) of the predicted mileage ensures the required efficiency $(99.5 \%)$ and accuracy of air filtration $[72,87]$. This is due to the phenomena occurring in the initial period of the filtration process of the fibrous material. Therefore, the frequency of air filter servicing (filter cartridge replacement with a new one) may affect engine wear and durability. 


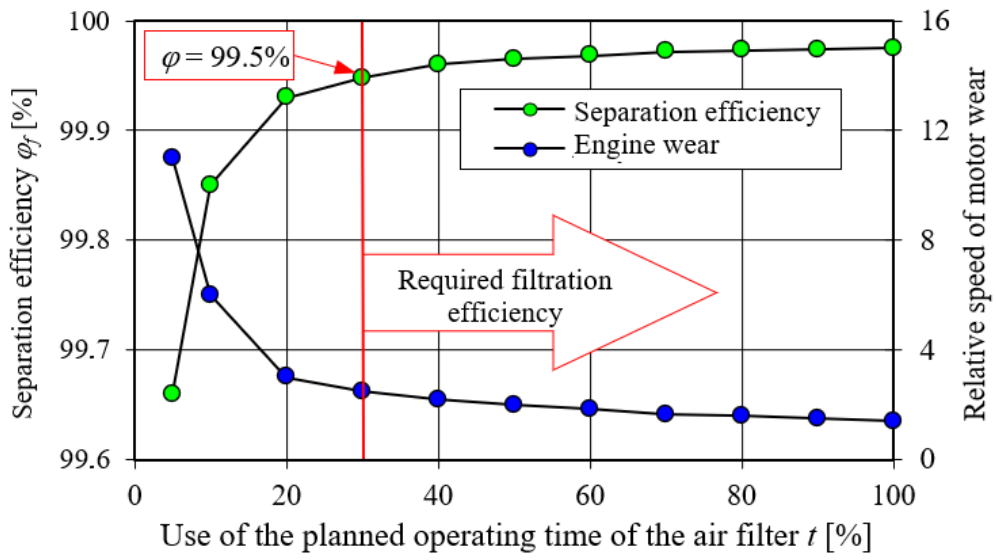

Figure 33. Separation efficiency and engine wear rate as a function of air filter run time. Figure made by the authors using data from $[89,106]$.

The length of this period depends on the type and parameters of the filter material, the concentration and granulometric composition of the dust, and the filtration rate. Figure 34 shows the results of experimental tests of several filter materials that differ in the length (duration) of the initial filtration period [113]. With the increase of the mass of dust retained in the filtration layer (increase of the km coefficient), the filtration efficiency of the tested cartridges assumes increasingly higher values. The required value of filtration efficiency $\left(\varphi_{w}=99.9 \%\right)$ is achieved by filter cartridges working in the same conditions (the same value of dust concentration and air flow) after different time. Insert A achieves an efficiency of $\varphi_{w}=99.9 \%$ after obtaining a dust absorption coefficient $k_{m A}=110.7 \mathrm{~g} / \mathrm{m}^{2}$. For inserts B, C, D, and E made of other filtration materials the initial period (time of obtaining the required filtration efficiency) is much shorter. For inserts $\mathrm{E}$ (polyester + PTFE membrane) and $\mathrm{D}$ (cellulose + polyester + nanofiber), this period ends at the earliest when the dust absorption coefficient $k_{m E}=5.77$ and $k_{m D}=7.22 \mathrm{~g} / \mathrm{m}^{2}$, respectively, is reached. For cartridge $\mathrm{B}$ (polyester), the initial period ends at a dust absorption coefficient of $k_{m B}=31.9 \mathrm{~g} / \mathrm{m}^{2}$, and cartridge $C$ (cellulose + polyester) for a coefficient of $k_{m C}=48.5 \mathrm{~g} / \mathrm{m}^{2}$ (Figure 34).

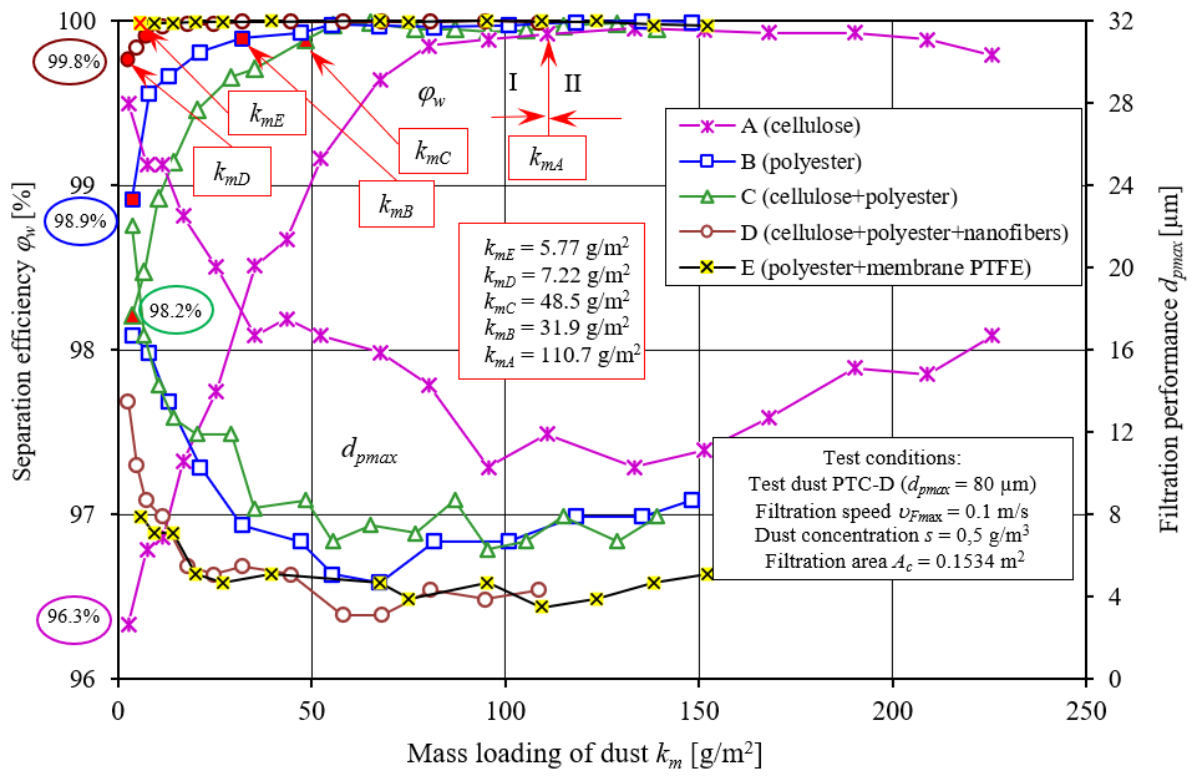

Figure 34. Separation efficiency $\varphi_{w}$ and filtration performance $d_{p m a x}$ depending on the dust mass loading $k_{m}$ of the tested filter cartridges [113]. 
At this time, there are large dust grains in the air behind the filters. The largest dust grain sizes $\left(d_{\text {max }}=28 \mu \mathrm{m}\right)$ were recorded downstream of cartridge A (cellulose), and the smallest $\left(d_{\text {pmax }}=7.9 \mu \mathrm{m}\right)$, downstream of cartridge $\mathrm{E}$, which is closely related to the initial filtration efficiency of these cartridges. This is due to the higher grammage, and smaller pore size of the filter materials tested.

The initial filtration efficiencies of the tested cartridges take on different values. The lowest value $\left(\varphi_{w 0 A}=96.3 \%\right)$ was recorded for the filter cartridge made of filtering material A (cellulose). Inserts B, C, D, and $\mathrm{E}$ have higher values of initial filtration efficiency, respectively: $\varphi_{w 0 B}=98.9 \%, \varphi_{w 0 C}=98.2 \%, \varphi_{w 0 D}=99.8 \%, \varphi_{w 0 E}=99.97 \%$ (Figure 34).

Low initial filtration efficiency and the presence of large dust grains in the cleaned air during the initial period of filter operation (after replacing the contaminated filter insert with a new one) can affect the accelerated wear of mainly P-PR-CL association. Thus, frequent, unjustified filter cartridge replacement may be the cause of accelerated wear of engine components.

On the other hand, the authors of the paper [114] believe that the wear of the friction pair "cylinder-piston rings" and thus the durability of the internal combustion engine depends not only on the efficiency of the inlet air filtration and the wear resistance of the parts, but also on the design of the intake manifold. In the intake manifold of a multicylinder car engine (Figure 35a), due to the rapid twisting of the flowing air in the ducts and the associated effect of the inertial force on the dust particles, uneven distribution of the dust particles to the individual engine cylinders can occur, resulting in uneven wear of the piston-cylinder group.

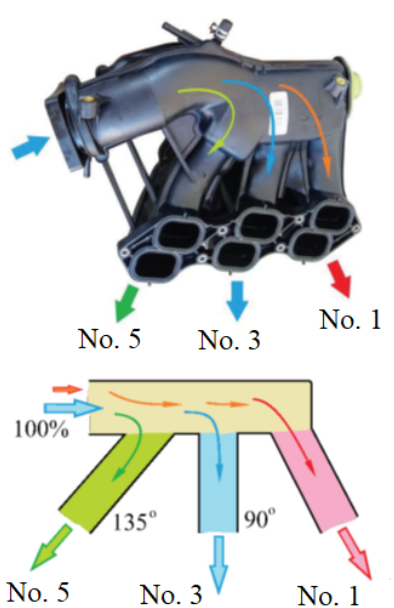

(a)

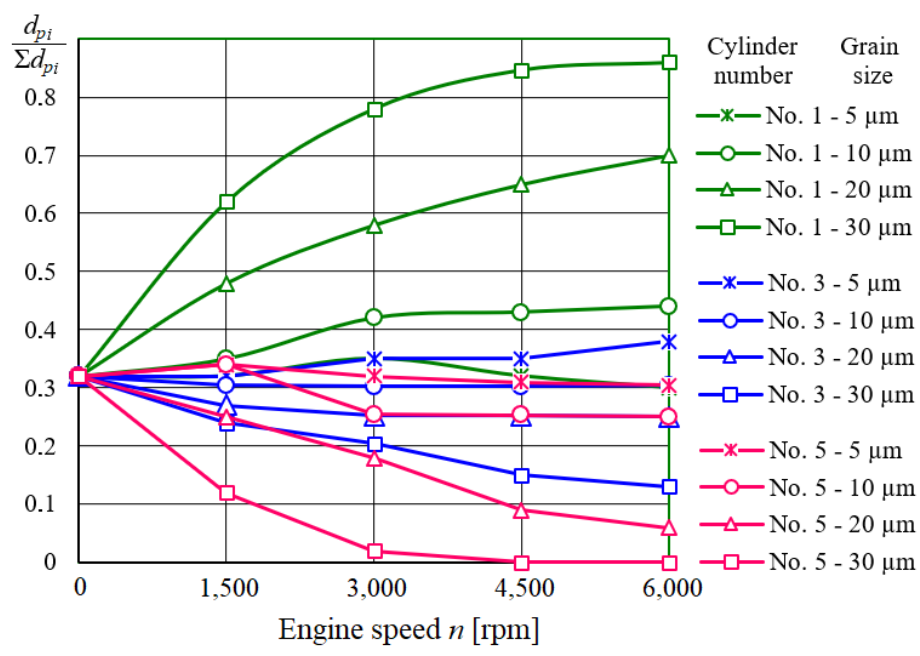

(b)

Figure 35. Intake manifold with different outlet angles (1, 3, and 5-engine cylinder numbers): (a) construction and functional diagram, (b) the ratio of the number of dust particles $d_{p i}$ the size of 5 , 10,20 , and $30 \mu \mathrm{m}$ in the cylinders to the total number of particles $\Sigma d_{p i}$ at the inlet at different rotation frequency $n$ of the crankshaft. The figure was made by the authors based on data from [114].

Simulation studies were carried out in the air velocity range of 5-20 m/s in branched manifold channels with diversion angles of $45^{\circ}, 90^{\circ}$, and $135^{\circ}$ for the most characteristic particle sizes of 5-30 $\mu \mathrm{m}[114,115]$. The computational results showed that the dust particles deviate from the air flow line due to inertia and can move through the side outlet the larger the particle size, channel deflection angle and air velocity-Figure 35b. The uneven distribution of particles in some modes of operation is so great that as much as $75-85 \%$ of the dust can enter the outermost cylinder, furthest from the inlet to the intake manifold. This explains the reason for the uneven local abrasive wear of the cylinder-piston group and valve mechanism components in individual cylinders. 
According to the author of the paper [116], the excessive presence of sulfur in the fuel may be the cause of additional corrosion wear of piston rings and cylinder liners, i.e., those engine elements which are in contact with exhaust gases. This type of corrosion wear caused by sulfuric acid intensifies when the engine is operated at low temperatures and when exhaust gas recirculation is used. It can be seen from Figure 36 that the rate of cylinder liner wear increases with increasing particle size in the range of 15-30 $\mu \mathrm{m}$ and engine speed in the range of 1000-2500 rpm. The dust samples used in this study were obtained from the Jordanian desert. The wear rate of the cylinder liner increased significantly when sulfur was cycled into the fuel at $0.03 \%, 0.6 \%$, and $0.1 \%$ (Figure $36 \mathrm{~b}$ ). A maximum wear rate of $2.41 \mu \mathrm{m} / \mathrm{h}$ was obtained when the engine was operated at $n=2500 \mathrm{rpm}$, for maximum particle size $(30 \mu \mathrm{m})$ and maximum sulfur content $(0.1 \%)$ in the fuel.

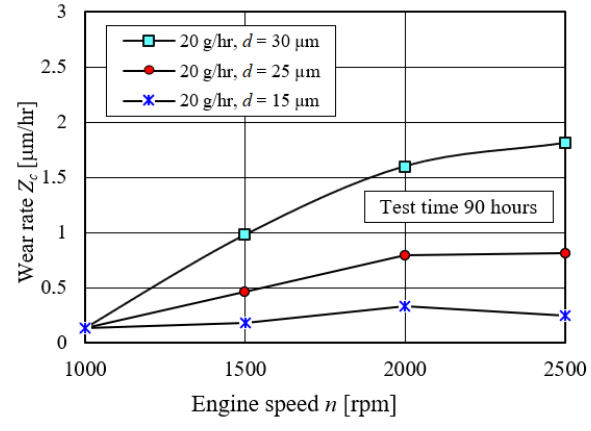

(a)

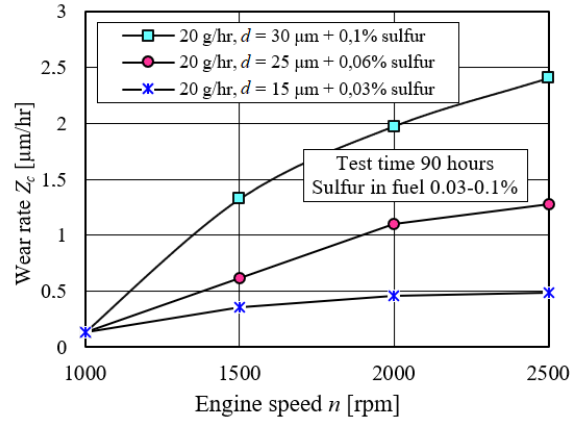

(b)

Figure 36. Cylinder liner wear rate as a function of engine speed: (a) for different sizes of dust grains in the 15-30 $\mu \mathrm{m}$ range, (b) for different sizes of dust grains and with the addition of sulfur in the fuel. Figure made by the authors using data from [116].

Figure 37 shows the effect of dust particles dosed with air and sulfur added to fuel on engine cylinder liner wear along its formation. It can be clearly seen that the abrasive wear takes maximum values at the top dead center (TDC), slightly smaller values at the bottom dead center (BDC) and very little values at the other locations of the bushing (Figure 37a). When the engine burns fuel with added sulfur, cylinder liner wear increases because corrosive wear occurs in addition to abrasive wear caused by dust particles. The total wear near TDC is higher than elsewhere in the cylinder liner [116]. This is probably due to the difficult operating conditions of the rings in this zone: very low piston and ring velocity, which disappears to zero at TDC. The upper ring is exposed to high temperature gases (proximity to the combustion chamber), which causes the oil near the upper ring to evaporate and reduce its viscosity. As a consequence, the lubricating wedge disappears, so that most of the time there is metal-to-metal contact which is the cause of abrasive wear.

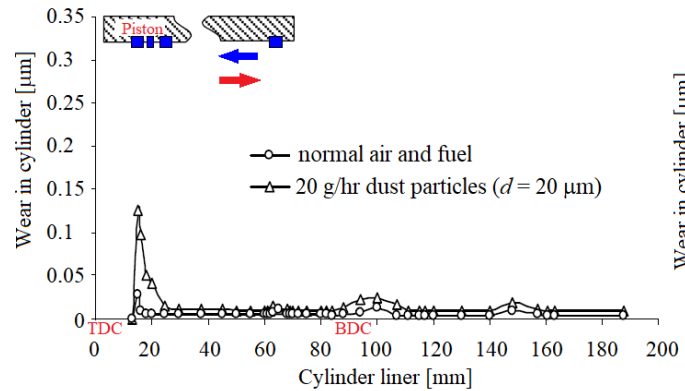

(a)

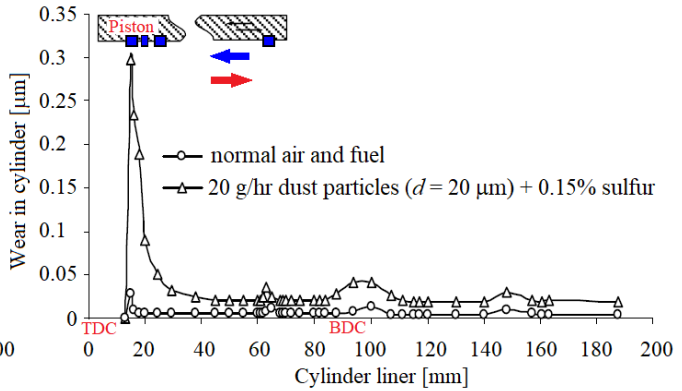

(b)

Figure 37. Cylinder liner wear along its length at $2000 \mathrm{rpm}$ and after $120 \mathrm{~h}$ of engine operation: (a) effect of dust particles, (b) effect of dust and sulfur particles. Figure made by the authors using data from [116]. 
Figure 37a shows the relationship between the wear of the first and second piston rings and the mass of dust dispensed into the cylinder. The wear of the first ring, due to high temperature and pressure, lower oil viscosity, is higher than that of the second ring. The wear increases linearly as the intensity of the dust mass flowing into the cylinder increases [116].

The relationship between the wear of the first and second piston ring and the degree of sulfur content in the fuel is shown in Figure 38b. The course of ring wear is similar (linear) to that shown in Figure 38a, but changes with less intensity. This shows that dust particles have a greater effect on piston ring wear than sulfur in fuel. That is, the abrasive wear rate of engine components is higher than the corrosive wear rate.

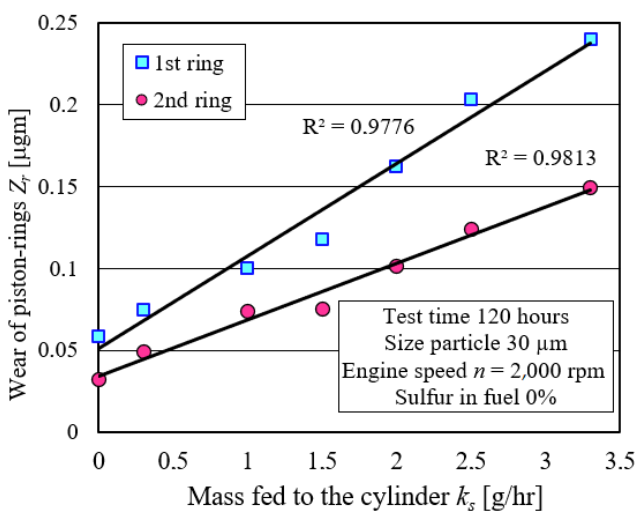

(a)

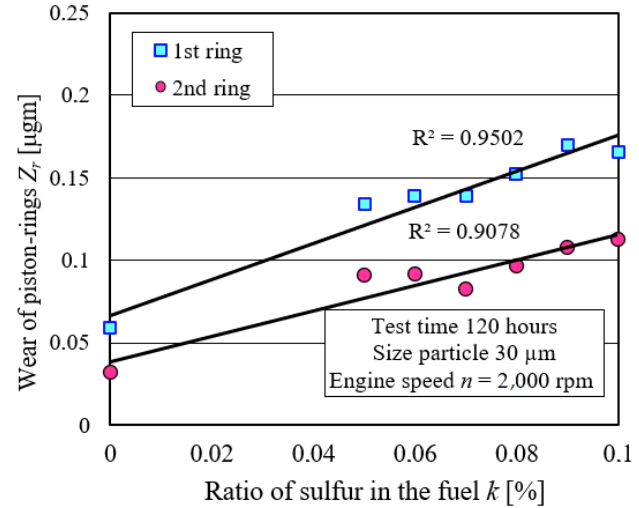

(b)

Figure 38. Piston ring wear rate at engine speed $n=2000 \mathrm{rpm}$ depending on: (a) the mass of dust dispensed into the cylinder, (b) the percentage of sulfur in the fuel. The figure was made by the authors based on data from [116].

Experimental studies of the wear of piston-cylinder assembly components of five 4-cylinder $85.3 \mathrm{~kW}$ engines were presented in [117]. Each of the five tested engines was equipped with a completely new set consisting of: honed sleeve, piston, rings, pins, and valves. The first stage of the study involved running the engines during the run-in period for $10 \mathrm{~h}$ at 1400-2800 rpm and varying load and with increased air dust. The engine load and speed were increased systematically from minimum to maximum value. The second stage of testing consisted of seven 3-h cycles of $2 \mathrm{~h} 50 \mathrm{~min}$ full load at $2800 \mathrm{rpm}$ and $10 \mathrm{~min}$ idle to obtain a total of $21 \mathrm{~h}$ of engine operation. In this stage, test dust containing mainly $73.7 \% \mathrm{SiO}_{2}$ and $14.8 \mathrm{Al}_{2} \mathrm{O}_{3}$ was precisely metered into the engine intake manifold at a rate of $1.3 \mathrm{~g} / \mathrm{h}$, corresponding to an ambient dust concentration of about $8 \mathrm{mg} / \mathrm{m}^{3}$. To avoid the accumulation of dust and wear products inside the engine lubrication system, an additional external fine oil filtration system was added.

The wear of the pistons was expressed by the change in their average radius, while the wear of the top, middle, and bottom ring was expressed by the change in the size of the end gaps: PI, PII, and PIII. The lapping operation causes only 1.3-3.9 $\mu \mathrm{m}$ of cylinder liner wear due to the change in the roughness parameters of the cylinder liners. The ring wear during engine run-in averages $53.2 \mu \mathrm{m}$ for top rings, $153.2 \mu \mathrm{m}$ for middle rings, and $369 \mu \mathrm{m}$ for bottom rings (Figure 39a). During the second stage of testing, the average wear is respectively-for cylinder liners: $4.0-24.3 \mu \mathrm{m}$, for pistons: $2.6-4.4 \mu \mathrm{m}$, and for rings: $\Delta \mathrm{PI}=340 \mu \mathrm{m}, \Delta \mathrm{PII}=560 \mu \mathrm{m}, \Delta \mathrm{PIII}=960 \mu \mathrm{m}$ (Figure 39b).

From the above analysis, it can be seen that wear of the elements of the friction pair "cylinder liner-piston rings" and other friction associations in the engine is inevitable due to the presence of hard dust grains in the engine intake air. This is due to the fact that standard cellulose-based filter materials used for engine intake air filters have filtration efficiencies in excess of $=99.5 \%$ and dust grain retention accuracy of more than 2-5 $\mu \mathrm{m}$ [113]. It follows that all dust grains above $2-5 \mu \mathrm{m}$ enter the engine cylinders. From available liter- 
ature data, all dust grains above $d_{p} \geq 1 \mu \mathrm{m}$ cause accelerated wear of internal combustion engine components $[76,94,95,106]$. The only way to protect engines from excessive wear of frictionally cooperating surfaces is to use materials with an engine inlet air filtration accuracy above $1 \mu \mathrm{m}$. Such possibilities are created by polymer nanofibers, i.e., fibers with a diameter below $1 \mu \mathrm{m}$ obtained by electrospinning [118-123].

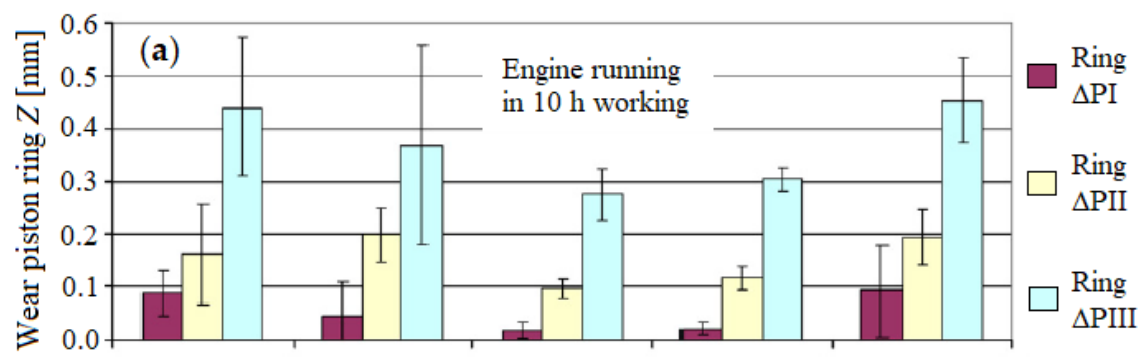

Engine no. 1 Engine no. 2 Engine no. 3 Engine no. 4 Engine no. 5

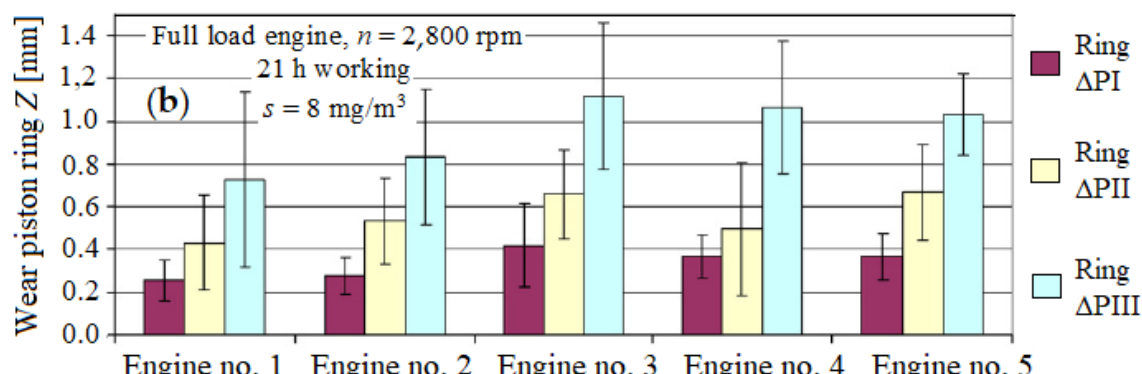

Figure 39. Piston ring wear: (a) after $10 \mathrm{~h}$ of engine run-in test, (b) after $21 \mathrm{~h}$ of engine operation at full load, at $2800 \mathrm{rpm}$, and dust concentration in intake air $s=8 \mathrm{mg} / \mathrm{m}^{3}$. Figure made by the authors using data from [117].

Nanofibers have completely different and new properties compared to standard fibers. First of all, they have a large surface area in relation to their weight and a significantly higher strength, and they also have a higher chemical activity and higher moisture sorption. In automotive technology, nanofibers with very small diameters of about 50-800 nm are used. Companies producing filter media using nanofibers have developed their own technologies for this purpose, such as Donaldson's Ultra-Web ${ }^{\circledR}$ and Fibra-Web ${ }^{\circledR}$ technology, Finetex Mats $^{\mathrm{TM}}$ from Finetex Technology Inc. and AM-SOIL Ea Air Filters. Due to the limited mechanical and strength properties of the nanofiber thin film $(1-5 \mu \mathrm{m})$, it is applied over a substrate of conventional filter materials that have greater thickness and strength.

A thin nanofiber layer applied on the inlet side of a standard filter bed, which can be cellulose, nylon, or polyester (Figure 40) traps contaminant particles before they penetrate deep into the filter material [124-126].

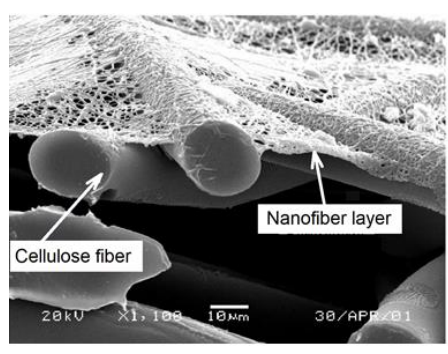

(a)

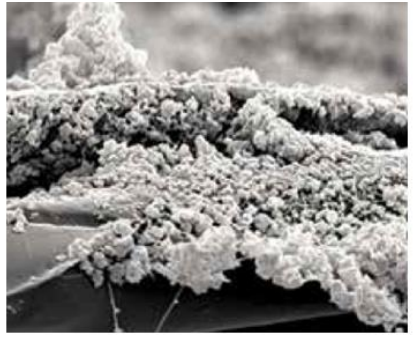

(b)

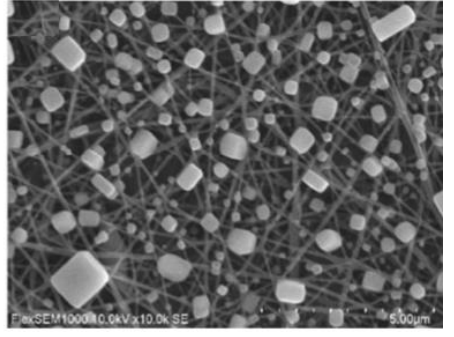

(c)

Figure 40. Filter bed made of cellulose and nanofiber layer: (a) nanofiber layer applied to the substrate-cross-sectional view of the bed [124], (b) dust layer retained on the nanofiber layer [125], (c) dust grains retained on the nanofiber layer [126]. 
The use of nanofibers as an additional layer applied to standard air filter materials used in motor vehicles significantly improves filtration efficiency and accuracy, but unfortunately increases flow resistance. Figure 41 shows the filtration efficiency of a nanofiber filter medium with a cellulose substrate on which a layer of nanofibers with a thickness of $300 \mu \mathrm{m}$, a weight $g_{m}=0.1 \mathrm{~g} / \mathrm{m}^{2}$ and a fiber diameter in the range of $40-800 \mathrm{~nm}$ was placed [127]. For filtration velocity $v_{F}=0.03 \mathrm{~m} / \mathrm{s}$ and dust grains in the range $d_{p}=0.2-4.5 \mu \mathrm{m}$, the filtration efficiency of this bed reaches values $\varphi=64-99 \%$, respectively. For a much higher filtration velocity $v_{F}=0.2 \mathrm{~m} / \mathrm{s}$, the filtration efficiency reaches a slightly lower level. These efficiency values are much higher than those of cellulose-based and commercial nanofiber materials (Figure 40).

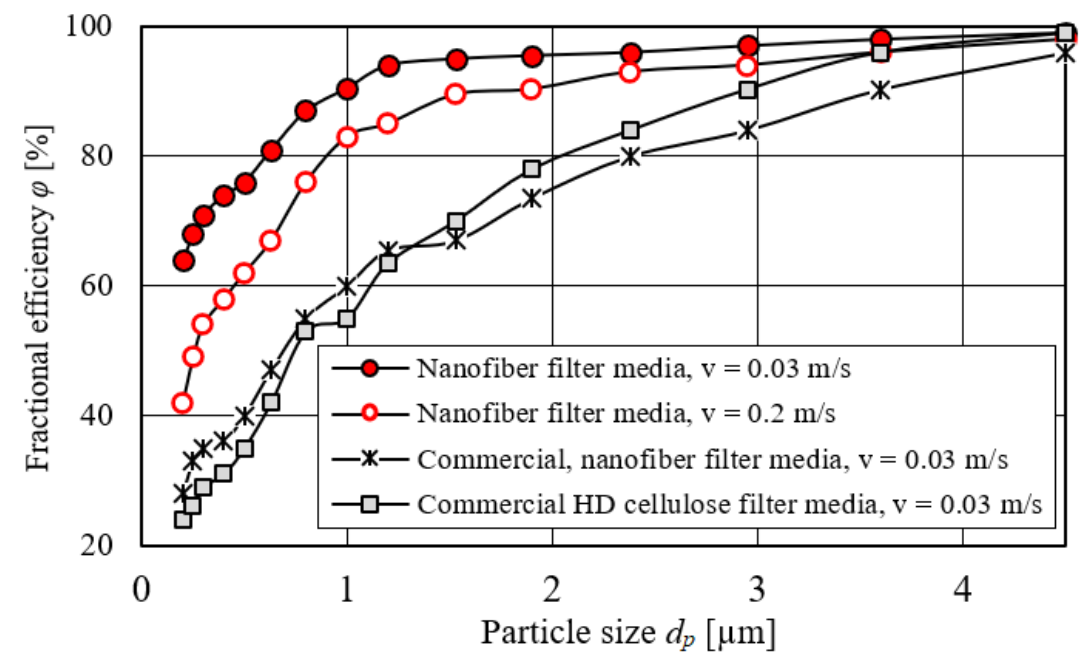

Figure 41. Pleated filter elements made of cellulose fibers, nanofiber layer, and cellulose fibers filtration efficiency. Figure made by the authors using data from [127].

The second area of activity aimed at reducing friction and wear of elements of the friction pair "cylinder liner-piston rings" and other friction bonds is focused on the application of innovative technologies. Surface modification and coating, suitable lubricating oil or surface texturing are important techniques for reducing friction between two friction surfaces. One of the factors preventing excessive wear of engine elements is the application of antiwear coatings on the most thermally stressed and wear-prone elements of the piston-ring-cylinder unit. The results of research on the influence of introduction of these coatings for various parameters of internal combustion engines, both car and aircraft, are presented in [128-135].

Examples include thermal application of advanced cylinder liner coatings such as nickel and diamond-like carbon nanocomposite [131], coating of piston rings (PR) with molybdenum (Mo) powder [132], coating of diamond-like carbon (DLC) on piston rings and Fe coating on cylinder liner [133], coating of alumina nanopowder on piston rings and CrN coating on cylinder liner [134], and thermal spraying of coatings on ring faces [135].

Surface texturing of piston rings and cylinder liners is an innovative technology to reduce friction and improve wear resistance of these most heat and strength stressed components. After conventional honing, the surface texture of cylinder liners can be changed by a number of techniques such as flat honing, helical honing, laser honing, and laser texturing [136]. The honing angle or the angle of the transverse notch created by the honing process is believed to affect the tribological behavior of the sleeve-ring tribosystem. Surface texturing, as an effective method to improve the tribological properties of P-PR-CL friction pairs, has received much attention in the relevant scientific literature [137-141]. Studies have included the influence of texture parameters: the shape of indentations, their size, and surface ratio on the reduction of friction and wear of sliding elements in an engine [137], the influence of honing angles (20-100 ) under boundary lubrication conditions on the tribological behavior of the "cylinder liner-piston and piston ring" 
pair [138], effect of topography of DLC coating applied on piston ring and cylinder liner on tribological characteristics of friction pair [139], effect of texture of thread grooves with different widths on cylinder liner surfaces and texture of circular indentation on piston ring on diesel engine performance [140], and effect of normal load on changes of liner surface texture [141].

According to the authors [142], well-chosen surface texturing parameters can improve the tribological properties of lubricated surfaces under relative sliding motion conditions by creating a hydrodynamic lift phenomenon at the interface between the ring and cylinder liner surfaces. The test results of the authors of paper [143] showed that under different lubrication conditions, laser texturing of the cylinder liner can effectively reduce the friction force in the reciprocating motion of the ring-sleeve pair. The average friction coefficients of the laser textured cylinder liner-ring pair are reduced by about (18.6-37.6\%). The authors of the paper [144] optimized textures with diameters of $100 \mu \mathrm{m}$ and $120 \mu \mathrm{m}$ on a parabolic piston ring and showed a reduction in friction of $27 \%$ and $21 \%$ compared to a ring without texture.

The authors of the paper [145] stated that reduction of friction and wear can affect engine performance and can be achieved by using proper honing technique.

In [146], the effect of microstructure laid on the cylinder liner of an internal combustion engine on the lubrication condition of the control ring was investigated. Measurements using a floating sleeve engine showed that the microstructure improved lubrication conditions by reducing hydrodynamic friction.

Among all these methods, surface texturing has become one of the main methods to improve the tribological properties of mechanical pairs undergoing relative sliding motion.

In conclusion of this section of the analysis, it should be stated that a large number of factors influence the wear of engine friction pair components. These are dust parameters (grain size, hardness, and shape), properties of the material from which engine elements are made, engine operating conditions (rotational speed, load size, operating temperature), efficiency and accuracy of inlet air filtration, quality of servicing air and oil filters, type and quality (sulfur content) of fuel used, and conditions (value of dust concentration in the air) in which a car is used. It is impossible to carry out research comprising all these factors. Therefore, for a number of years, experimental tests have been carried out, which evaluate the wear of only single or several factors simultaneously. Each researcher uses a different methodology and test conditions. Moreover, the researchers use different wear indicators. Therefore, the comparison of results is not always unambiguous.

\section{Effect of Wear of P-PR-CL Junction Elements on Engine Operation}

Wear and tear of the cylinder liner and piston rings caused by contaminants that penetrate the engine cylinders with the intake air as well as contaminants contained in the oil causes a loss of compressed medium and thus a pressure drop at the end of the compression stroke. The result is a decrease in engine power and an increase in specific fuel consumption. Excessive clearance in the P-PR-CL connection is the cause of increased flow of exhaust gases into the oil sump, which increases the temperature of the lubricating oil, decreases its lubricating properties and causes the oil to be blown out by the exhaust gases. The effect of this phenomenon is the disappearance of the "oil film", resulting in the system moving from fluid friction conditions to boundary friction. The increased clearance in the P-PR-CL combination intensifies the phenomenon of pumping action of the piston rings, thereby increasing oil consumption and exhaust gas toxicity.

Figures 42-47 show the results of the P-PR-CL assembly wear and its effect on changes in power, torque, specific fuel consumption, and exhaust gas blow-by into the crankcase of a $1.3 \mathrm{dm}^{3}$ turbocharged 4-cylinder ZS engine with charge air cooling and exhaust gas recirculation [45]. This is a passenger car engine with a maximum power of $66 \mathrm{~kW}$ achieved at $4000 \mathrm{rpm}$ and a maximum torque of $200 \mathrm{Nm}$ in the range $1750-2250 \mathrm{rpm}$. The honed cylinder liners had narrow, deep grooves (lubricating oil reservoirs) in the upper part made using laser machining. 

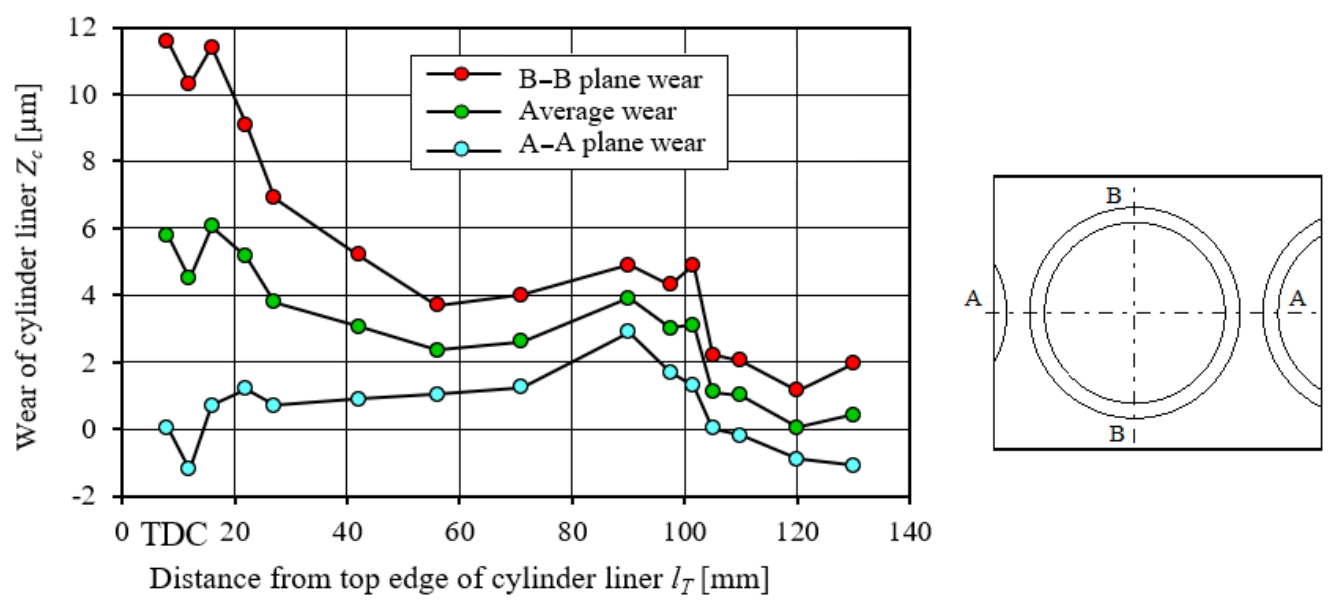

Figure 42. Average cylinder liner wear of a 4-cylinder turbocharged Diesel engine with $N_{\text {emax }}=66 \mathrm{~kW}$ in the plane perpendicular (B-B) and parallel (A-A) to the engine axis [45].

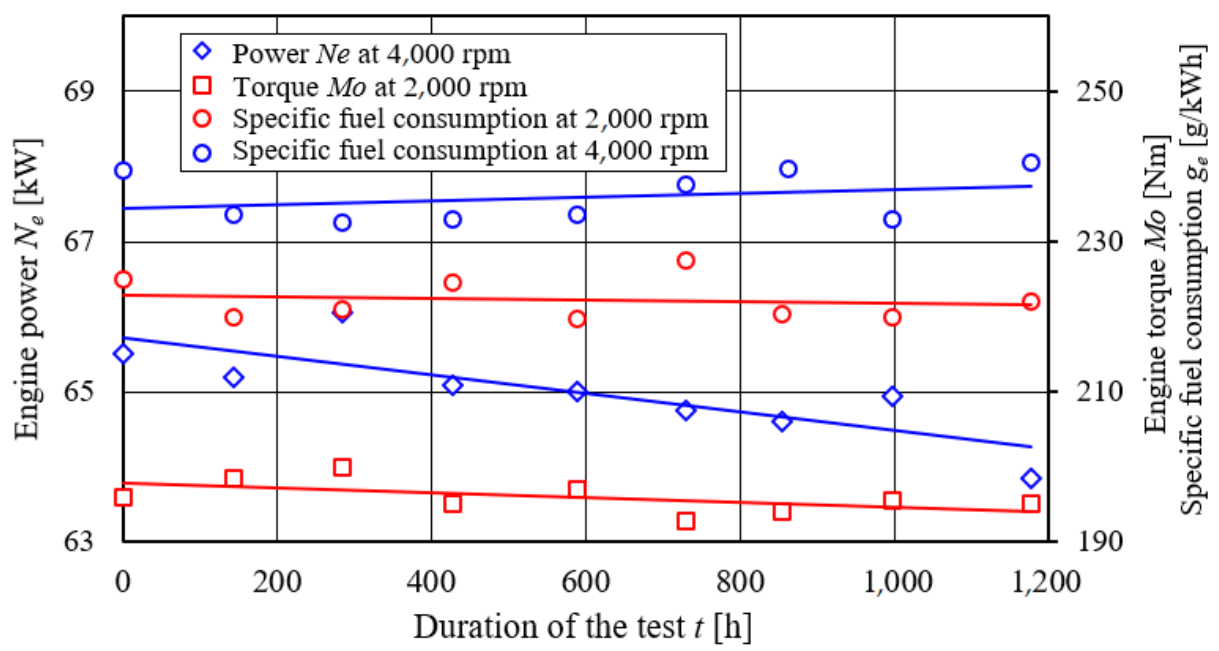

Figure 43. Variation of power and specific fuel consumption at $4000 \mathrm{rpm}$ and torque and specific fuel consumption at $2000 \mathrm{rpm}$. Figure made by the authors using data from [45].

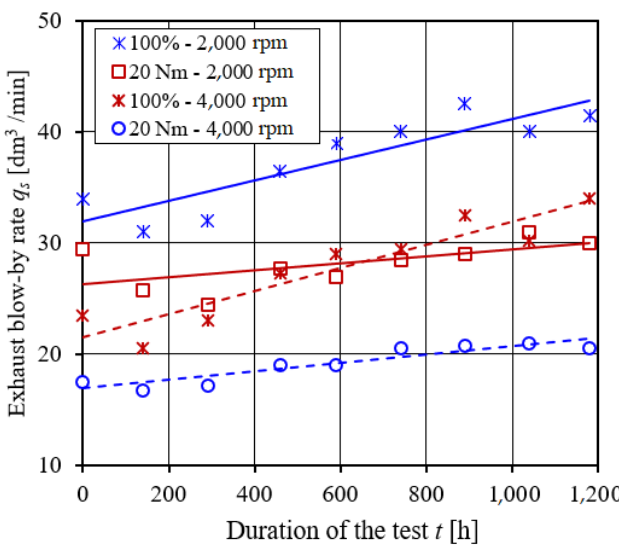

(a)

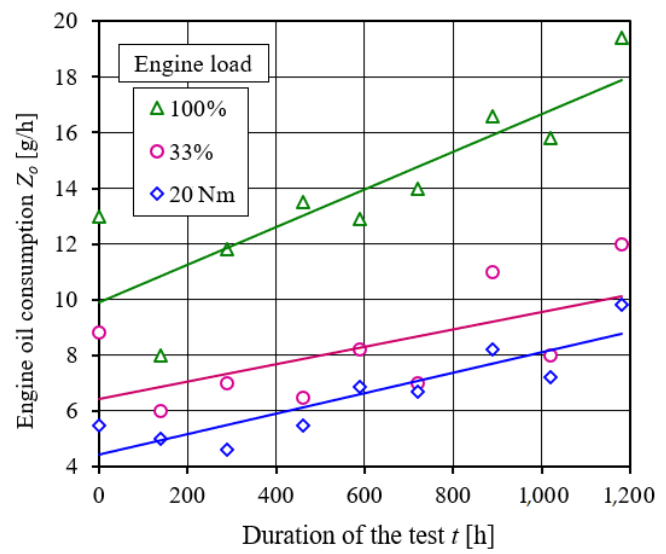

(b)

Figure 44. Effect of test duration on (a) exhaust blow-by volume at full and light engine loads, (b) engine oil consumption at different engine reliefs. Figure made by the authors using data from [45]. 


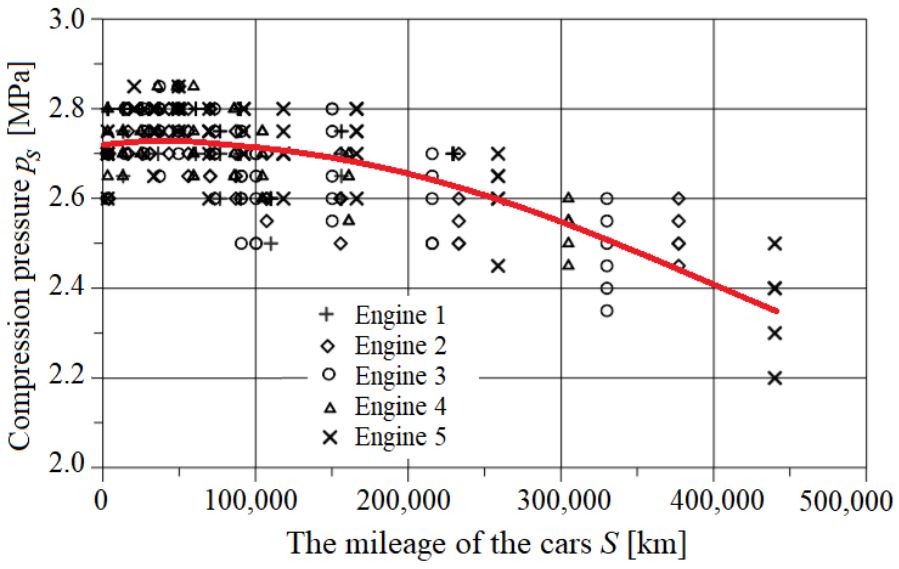

Figure 45. Changes in compression pressure in engine cylinders as a function of car mileage. Figure made by the authors using data from [147].

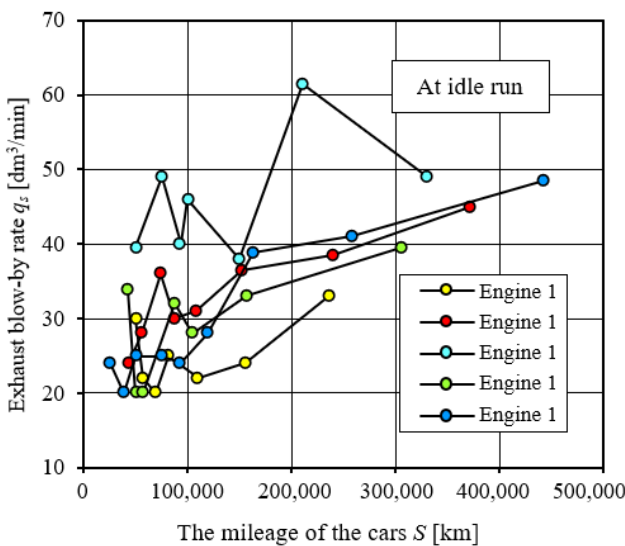

(a)

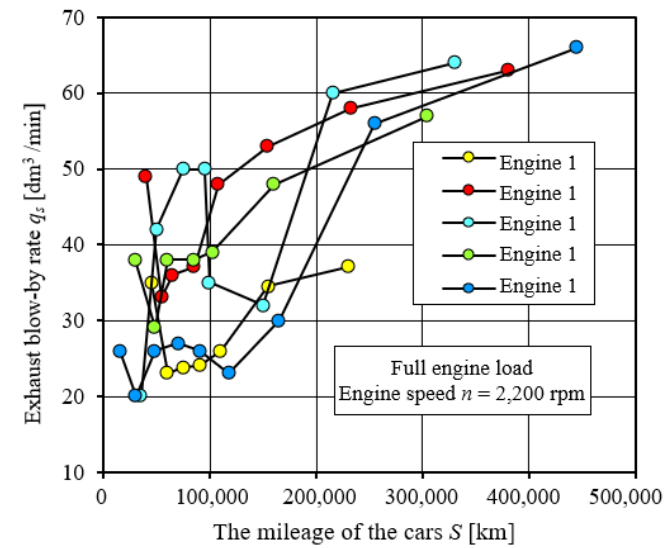

(b)

Figure 46. Changes in the intensity of exhaust gas blow-by depending on the course of cars during engine operation: (a) at idle, (b) at full load with $2200 \mathrm{rpm}$. Figure made by the authors using data from [147].

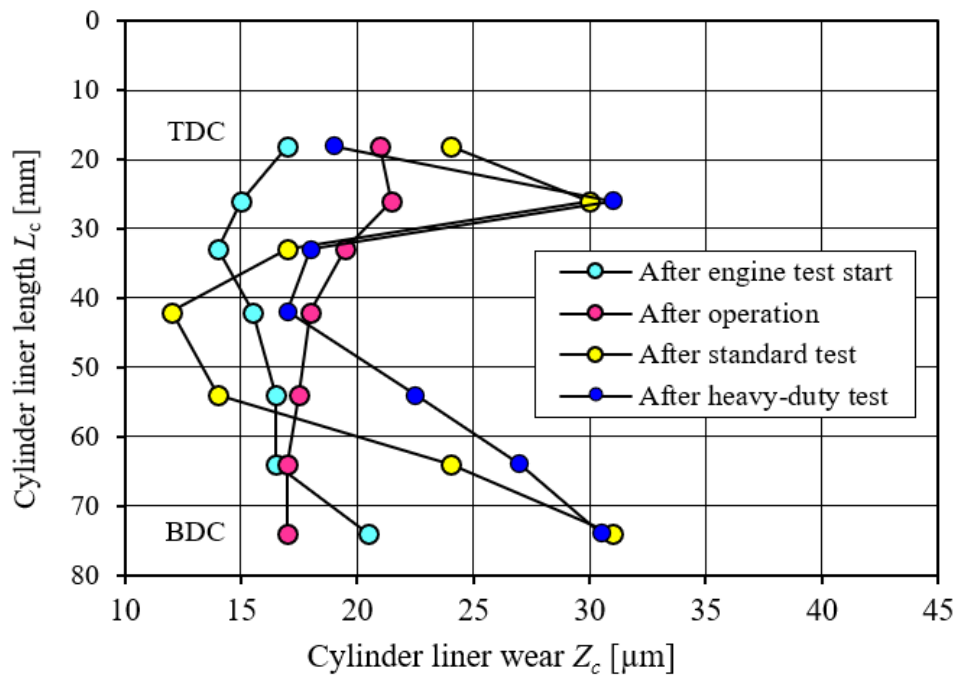

Figure 47. Cylinder liner wear profiles under different engine operating conditions and during engine start-up. Figure made by the authors using data from [148]. 
Long-term durability tests were conducted on the dynamometer bench, during which each engine was operated under heavy load conditions according to a special cycle that was repeated 336 times. The total operating time of each engine during the tests was $1200 \mathrm{~h}$. Every 42 test cycles or so, speed characteristics and other measurements were made to determine motor performance.

Figure 42 shows the cylinder liner wear averaged over all cylinders of both engines. The cylinder liner diameters in the direction parallel to the engine axis changed little, while in the perpendicular direction the diameter increments were larger, especially in the upper part of the liner. It should be assumed that the above changes in diameters are a consequence of both wear of the sleeve surfaces and their deformation. The average values for both directions indicate greater wear of the sleeves near the turning positions of the ring pack, especially the upper turning position.

The wear of the cylinder liner and piston rings caused by impurities penetrating into the cylinder liner together with the inlet air, as well as impurities contained in the oil, resulted in a decrease in the tightness of the piston crown space. As a result, a loss of the compressed medium occurred, and thus a pressure drop at the end of the compression stroke, and in consequence a decrease in the power of the tested engine by about $2.5 \%$ and an increase in specific fuel consumption by $3.4 \%$ (Figure 43 ).

Wear of the P-PR-CL association is at the same time an increase in the intensity of exhaust gas blow-by into the crankcase (Figure 44a), which causes an increase in the temperature of the lubricating oil, a decrease in its lubricating properties, and oil blow-by of the exhaust gases. The effect of this phenomenon is the disappearance of the "lubricating wedge," resulting in the system moving from fluid friction conditions to boundary friction.

After $1200 \mathrm{~h}$ of engine operation at full load and $4000 \mathrm{rpm}$, the blow-by rate increased by $61 \%$. This greatly accelerates the degradation of engine oil. The increased clearance in the P-PR-CL combination intensifies the phenomenon of pumping action of piston rings, thereby increasing oil consumption and exhaust toxicity. At the same time, engine oil consumption increased by 108\%, 96\%, and 113\% at 100\%, 33\%, and $20 \mathrm{Nm}$ loads, respectively (Figure $44 \mathrm{~b}$ ).

The results of testing the integrity of the combustion chamber of 5 examples of sixcylinder Diesel engines are presented in the paper [147]. These were engines with displacement $V_{S S}=6.8 \mathrm{dm}^{3}$ and power $N_{e}=110 \mathrm{~kW}$ used for driving trucks, which were exploited in similar conditions with an average mileage of 10,000 km per month. Changes in combustion chamber tightness as a result of increased wear of engine cylinder liners were determined on the basis of compression pressure measurements and the intensity of exhaust gas blow-by into the crankcase. The measurements of the intensity of the blow-by gases to the crankcase were carried out when the engine was idling and on the chassis dynamometer at full engine load in the range of the crankshaft rotational speed $n=1,570-2800 \mathrm{rpm}$. Until the car reached the mileage of $100,000 \mathrm{~km}$, the measurements were performed every 15,000 km, and after exceeding 100,000 km, every 50,000 km.

As a result of increased wear of the engine cylinder liners, the P-PR-CL junction tightness decreases, and thus the pressure at the end of the $p_{s}$ compression stroke decreases and the exhaust gas flow rate (blow-by) to the crankcase increases. With the mileage of vehicles in the range of $0-500,000 \mathrm{~km}$, the values of engine compression pressure decrease, but a definite decrease occurs only after the mileage of about 80,000 km (Figure 45). The measurement results were characterized by significant scatter.

The average compression pressure value after $500,000 \mathrm{~km}$ decreased by only $16 \%$ compared to the value at zero mileage. Exhaust blow-by intensities increased significantly: by $116 \%$ at idle, while the increase at full load was: $117 \%$ at $1570 \mathrm{rpm}, 149 \%$ at $1880 \mathrm{rpm}$, $194 \%$ at $2200 \mathrm{rpm}$ and 51\% at $2800 \mathrm{rpm}$ (Figure 46)

This was most probably due to the fact that the engines were being run-in during their first period of operation. Above $50,000 \mathrm{~km}$, the blow-by volume increased almost linearly with the vehicle mileage. The values of the intensity of the exhaust gas blowing into the 
crankcase of a fully loaded engine (Figure 46b) have higher values, especially after the mileage of $S=100,000 \mathrm{~km}$.

Figure 47 shows the results of engine cylinder liner wear after bench and operational tests [148]. The values of wear of cylinder liners during three reliable bench tests were compared with the results of long-term operation of the same type of compression-ignition internal combustion engine in a vehicle. Wear tests of cylinder liners of a 4CT90 internal combustion Diesel engine were carried out for the following operating conditions [148]:

- Tests during long term operation (5 engines);

- Bench testing according to the "standard test" described in BN-79/1374-04;

- Tests on a laboratory test bench according to "heavy load test";

- Tests on a laboratory test bench according to "start-up test".

The object of this research was a 4-cylinder internal combustion engine with ZS 4CT90, which is the driving unit of a Lublin delivery truck manufactured by WSK "Andoria". This is an engine with indirect injection, displacement $V_{s s}=2.417 \mathrm{dm}^{3}$, maximum power $63.5 \mathrm{~kW}$ at $4100 \mathrm{rpm}$, and maximum torque of $195 \mathrm{Nm}$ at $2500 \mathrm{rpm}$.

In order to compare the obtained results of wear and tear of the test bench tests with the wear and tear observed during operation of the vehicle (mileage of about 100,000 km), it was assumed that $1 \mathrm{~h}$ of operation of the engine on the dynamometer during the "heavy load test" and the "standard test" corresponds to the mileage of the vehicle of $60 \mathrm{~km}$, while start-ups take place every $7 \mathrm{~km}$ on average.

The average wear of the engine cylinder liners on the test bench after the "starting test" represents $85.5 \%$ of the total average wear during engine operation in a vehicle that has performed the same number of starts as during the starting test. For the "standard test" and "heavy load test", the average wear is higher and represents $103.4 \%$ and $107.5 \%$ of the average wear during engine operation in the vehicle, respectively.

A comparison of the cylinder liner wear profiles shows that for both the "standard test" and the "heavy load test" the highest wear values occurred near the upper and lower reciprocating positions of the piston rings. Of all three bench tests compared, the wear profile that was closest to the operating profile was obtained during the "start-up test".

The increased wear of the cylinder liners in the TDC area is due to several reasons:

- The action of high exhaust gas temperature on the piston bottom and the first piston ring, which causes a decrease in oil viscosity and a decrease in oil film thickness, and consequently a transition from liquid to boundary lubrication;

- Low value of piston velocity (in TDC piston velocity is 0 ) which is the cause of decrease of oil film thickness;

- Penetration of dust grains between mating surfaces of piston liner and piston rings, which get into the upper part of the cylinder liner together with the intake air;

- Increased wear in the plane perpendicular to the engine axis.

The research on the influence of wear of piston-cylinder unit elements of five 4-cylinder engines $\left(N_{e}=85.3 \mathrm{~kW}\right)$ on the changes of power, torque, specific fuel consumption and exhaust gas toxicity was presented in the paper [44]. The study was conducted in two stages: the first stage of the study involved running the engines in the run-in period for $10 \mathrm{~h}$ at $1400-2800 \mathrm{rpm}$ and variable load, the second stage lasted $21 \mathrm{~h}$ of engine operation and consisted of seven 3-h cycles of $2 \mathrm{~h} 50 \mathrm{~min}$ full load at $2800 \mathrm{rpm}$ and $10 \mathrm{~min}$ idle. During the tests, test dust was dosed into the engine manifold at a rate of $1.3 \mathrm{~g} / \mathrm{h}$, corresponding to an ambient dust concentration of approximately $8 \mathrm{mg} / \mathrm{m}^{3}$.

The tests showed noticeable differences between the engines in the obtained parameters. Statistically, the average power output of the five engines after running-in and after the full test slightly decreased by $2.5 \%$ from 83 to $80.9 \mathrm{~kW}$. The same trend was observed for the average torque, which changed from 285.5 to $277.9 \mathrm{Nm}$, also a reduction of $2.5 \%$. Fuel consumption increased by $3.6 \%$ from 364.3 to $377.4 \mathrm{~g} /(\mathrm{kWh})$, while total engine efficiency decreased by $2.2 \%$ from $22.6 \%$ to $22.1 \%$. A larger change was seen for exhaust emission factors: $\mathrm{CO}$ increased by $35 \%$ and $\mathrm{CH}$ by $40.8 \%$. 
The most reliable in the field of wear of engine elements are experimental tests conducted on a real object. In the available literature, the results of wear of P-PR-CL engine elements are presented, however, each researcher used an engine with different parameters and applied a different testing methodology. Engine bench tests and in-service tests were conducted. A common feature of these tests is the determination of the wear degree of the P-PR-CL friction pair and the effects of wear in the form of blow-by in the crankcase, a decrease in engine power and increased exhaust emissions. In engineering practice, the parameter that determines the degree of wear of the P-PR-CL association and evaluation of engine technical efficiency is the "pressure value at the end of the compression stroke".

\section{The Effect of Oil Contaminants on Engine Wear and Operation}

Exterior contaminants, mainly mineral dust particles, are introduced into the engine oil via the engine's supply system together with air and fuel as well as during maintenance work. As a result of the piston's movement in the BDC direction, the rings scrape oil together with mineral dust particles from the cylinder head into the oil sump. The engine oil also contains internal contaminants such as particles of dust and metals that were not removed during production, wear products of engine components, products of incomplete combustion and products of chemical conversion. The concentration of contaminants in oil is a function of the operating time of the oil in an engine and depends on: oil type and properties, amount of oil added, type of oil filtration system, as well as operating conditions. Contaminants in the oil of the lubricating system are distributed through the oil system to those tribological areas of the engine that are lubricated, e.g., to the journal-crankshaft, journal-camshaft, valve guide-valve stem combinations. Contaminants in the oil cause scratches and damage to the mating surfaces (Figure 48). They may settle in the material of bearing shells, and the effects of their presence in the form of abrasive wear will be felt even after oil change, which is the basic form of removing contaminants from the lubrication system.

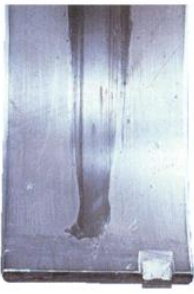

(a)

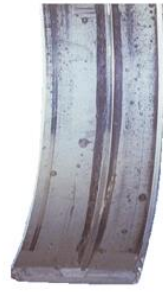

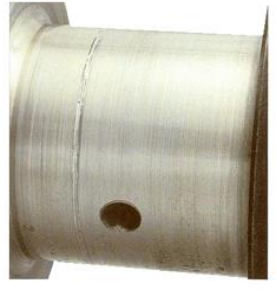

(b)

Figure 48. Wear view of pan (a) and crankshaft journal (b) of a car engine operated with a faulty air filtration system [149].

The effect of oil change frequency on the intensity of wear of the P-PR-CL junction and, consequently, on the decrease in pressure at the end of the compression stroke and the decrease in power and increase in specific fuel consumption of the Cummins N 14 engine was presented in [81]. The engine in which oil change was performed cyclically, every 25,000 miles, registered more than $18 \%$ decrease in power compared to the engine new and the engine in which oil change was performed twice as often (Figure 49).

Along with oil and filter changes, contaminants that caused accelerated wear of P-PR-CL association components were removed. Changing the oil at a lower frequency caused the accumulation of contaminants and an increase in their concentration, and thus increased wear of this association. This resulted in increased charge loss with leaks of the P-PR-CL association during its compression in the cylinder. The loss of charge mass from the cylinders is a decrease in engine inflation and power. 


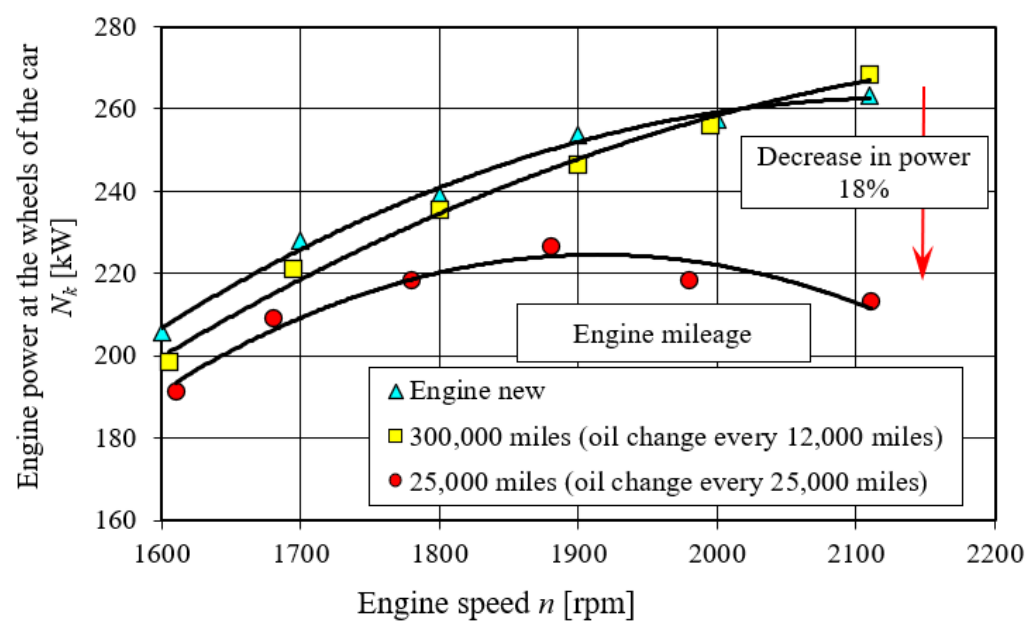

Figure 49. Power change of Cummins N14 engine new and after various vehicle mileages with oil changes every 12,000 and 25,000 miles. Figure made by the authors using data from [81].

The main source of contamination in engine oil are the dust particles that are carried with the air into the engine's cylinders and then transported to the oil sump by the piston rings. There are also other contaminants in the engine oil: metallic wear products, carbon deposits, and soot from the exhaust gases, fuel, and coolant. The grains that came into contact between the surfaces of the piston rings and the cylinder liner and were involved in the wear process may have crumbled into smaller grains and been smoothed out. Therefore, their influence on the wear of those engine components that are lubricated with oil may be different. The only way to reduce the effect of contaminants on engine components is to use oil filters and to change oil and filters regularly.

\section{Effects of Contaminants on Air Flow Meter Performance}

One of the most significant sensors that are on an internal combustion engine is the mass airflow (MAF) sensor used to measure the air entering the engine and determine the exact amount of fuel to be injected. The MAF sensor is a device that directly measures the mass of air entering the engine and sends a voltage signal to the engine control unit. Electronic engine fuel injection systems use the MAF sensor to control the air/fuel ratio. In doing so, they maintain the desired stoichiometric composition of the fuel mixture to achieve the best balance between fuel economy and emission reduction. Therefore, a high level of operational accuracy is required from the air flow meter sensor. MAF sensors are calibrated under steady flow conditions without turbulence or vortices with a long straight pipe to provide a turbulence-free, fully developed velocity profile. Unfortunately, these flow conditions are not maintained when MAF sensors are used in engines. Air flow causes turbulence around the sensor and interference with the sensor signal, resulting in unstable mass flow measurements [150].

To measure the mass of air flowing into the engine, mainly two types of mass air flow meters are used: with wire thermo-anemometer HLM (hot wire) and with layer thermoanemometer HFM (hot layer). As air flows past the hot wire, the wire cools, reducing its resistance, which in turn allows more current to flow through the circuit. As the current flows, the temperature of the wire increases until the resistance reaches equilibrium again. The amount of current needed to maintain the temperature is directly proportional to the mass of air flowing through the wire.

The basic element of the flowmeter is a cylindrical housing (Figure 50) through which the air flow to the engine passes. The measuring element of the Bosch wire thermoanemometer flowmeter is a 70- $\mu \mathrm{m}$-thick platinum wire stretched between the walls of the housing perpendicular to the direction of the air stream flow. 


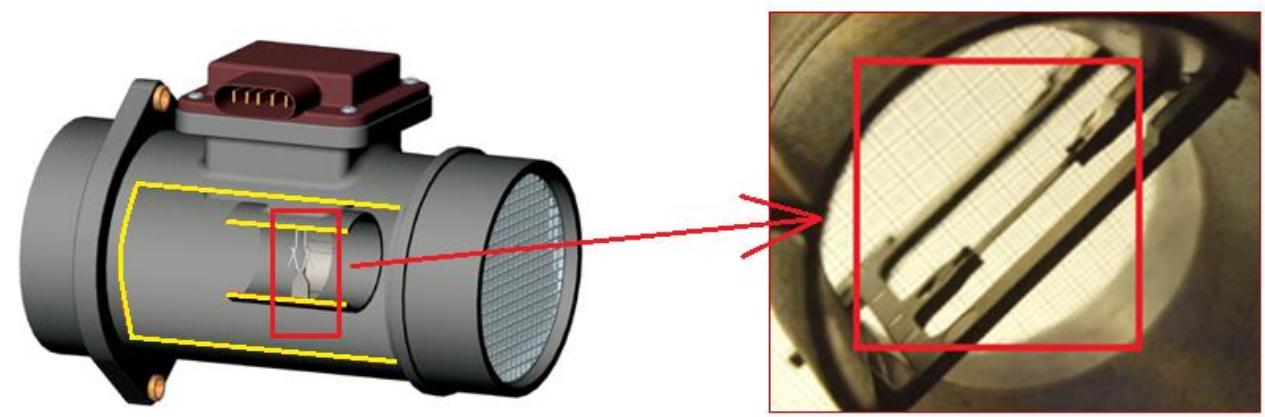

(a)

(b)

Figure 50. Air flow meter with wire thermo-anemometer: (a) general view, (b) measurement system The figure was made by the authors based on data from [151].

Layer thermo-anemometer (hot layer) air flow meters are built with three main components (Figure 51):

- $\quad$ The housing (measuring tube), which is built into the intake system after the air filter;

- A sensor (measuring element and electronics) located in the measuring tube;

- An inlet grid located at the inlet of the housing that protects against contaminants and forces turbulent flow, similar to a wire thermo-anemometer flowmeter.

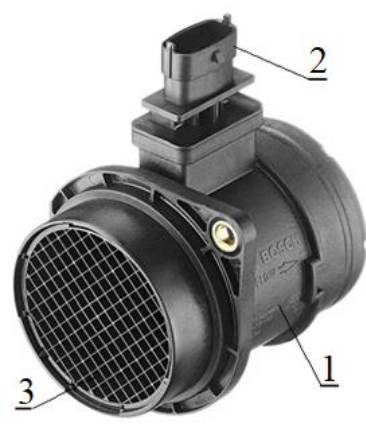

(a)

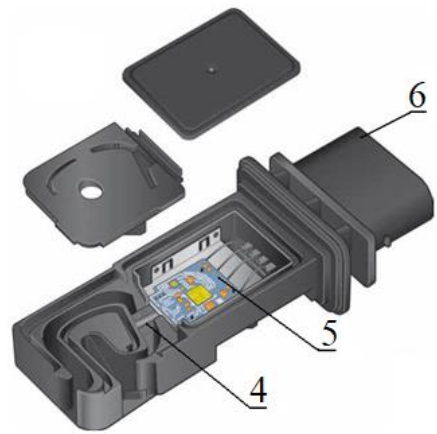

(b)

Figure 51. Bosch HFM6 type air flow meter: (a) general view (1-housing, 2-sensor, 3-inlet grille), (b) sensor (4-measuring element, 5-electronics, 6-digital interface). The figure was made by the authors based on data from [152].

The dust grains which are not stopped by the air filter move with the inlet air stream into the engine cylinders with an average speed $v_{z}=15-25 \mathrm{~m} / \mathrm{s}$, depending on the crosssectional area of the inlet duct. Some of the grains impact and some are deposited on the measuring element, forming a kind of thermal shield. The "wire flow meters" in particular are exposed to this type of contamination. The dust grains that are not stopped by the air filter settle on the surface of the wire, which traps the dust grains like a filter fiber in a porous filter baffle.

At the same time, the grains of $\mathrm{SiO}_{2}$ and $\mathrm{Al}_{2} \mathrm{O}_{3}$ minerals in the flowing air stream, which are characterized by sharp edges and very high hardness, strike the gauge wire, crippling and scratching its surface (Figure 52) and thus weakening the entire wire. A dust grain with a diameter $d_{p}=5 \mu \mathrm{m}$ moving with a velocity $v_{z}=15 \mathrm{~m} / \mathrm{s}$ hits the measuring element with a kinetic energy $E_{k}=1.56 \times 10^{-10} \mathrm{~J}$. A dust grain with a diameter $d_{p}=80 \mu \mathrm{m}$ (in the case of a faulty filter) moving with the same velocity has a kinetic energy more than 4000 times higher. 


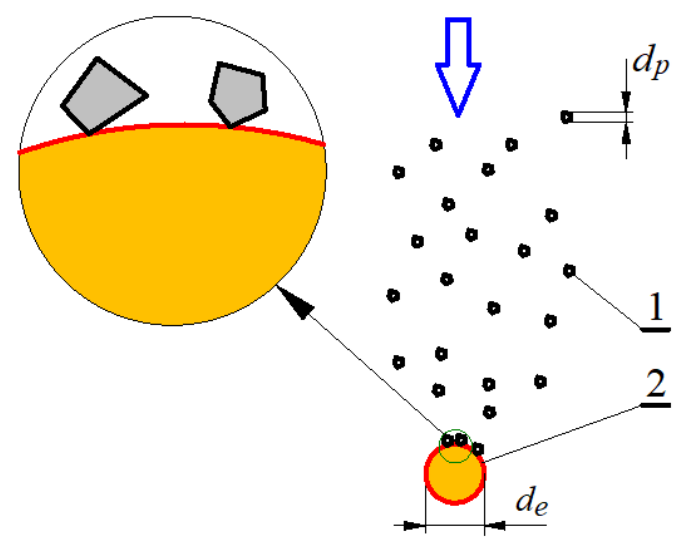

Figure 52. Flow diagram of dust grains hitting the heating wire of HLM air flow meter: 1—dust grains with diameter $d_{p}<5 \mu \mathrm{m}, 2$-heating element, $d_{e}=70 \mu \mathrm{m}$-diameter of the heating wire.

A malfunctioning filter or a leak in the air supply system causes accelerated wear of the flow meter heating wire, which leads to its failure even after several thousand kilometers. Over time, some of the dust grains are retained on the wire and form a layer whose thickness increases with the number of incoming grains-Figure 53.

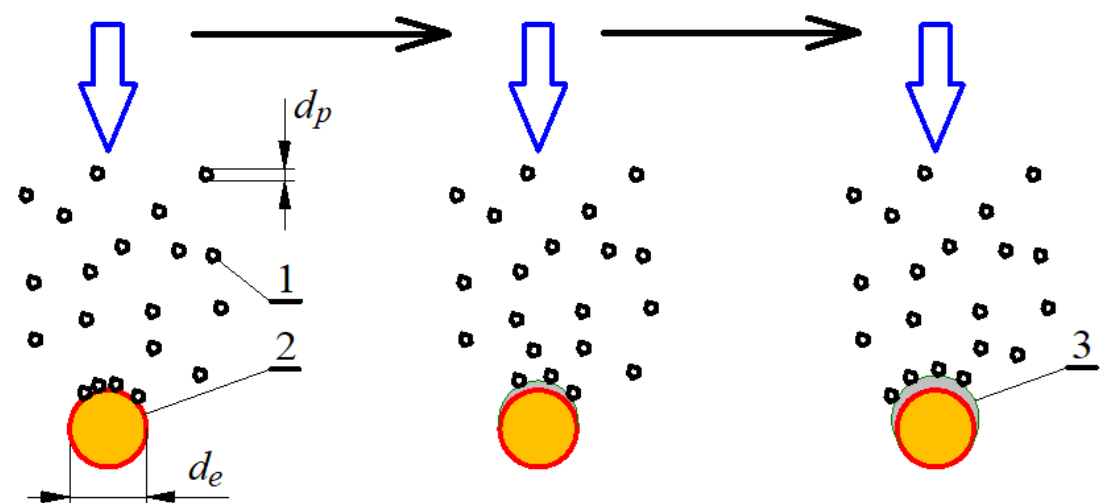

Figure 53. Diagram of dust grains deposition on the heating element (wire) of the LFM air flow meter: 1-dust grains with diameter $d_{p}<5 \mu \mathrm{m}, 2$-heating element, 3-layer formed by dust grains, $d_{e}=70 \mu \mathrm{m}$-diameter of heating element (wire).

The resulting layer, whose basic component is silica $\mathrm{SiO}_{2}$, is a good insulator that has a thermal conductivity coefficient of $\lambda_{s}=0.651 \mathrm{~W} / \mathrm{m}-\mathrm{K}$, which is more than 100 times lower than the thermal conductivity coefficient of the material (platinum $\lambda_{p}=71 \mathrm{~W} / \mathrm{mK}$ ) from which the heating wire is made.

Moisture contained in atmospheric air can also settle on the measuring element. The flowing air cools the dust-laden heating wire much less intensively. Thus, the value of the current needed to heat the wire is lower. The information about the value of the air stream sent to the on-board computer is different than if the heating wire was completely clean.

The engine intake air stream also contains contaminants in the form of:

- Oil particles which are fed into the air supply system via the crankcase ventilation system, e.g., as a result of a defective oil separator;

- Carbon deposited in the flow meter due to a defective exhaust gas recirculation system.

These deposits on the measuring element of the flow meter are usually caused by the reverse flow of the air stream in the direction from the engine to the air filter. These backflows are most often caused by pulsations caused by cyclic intake of air to individual engine cylinders during intake valve opening periods. 
Layer flow meters are more resistant to contaminations, since only a part of the air stream flows over the measuring element. At the inlet and outlet of the casing there is a mesh (Figure 54) whose task is to protect the inside of the flowmeter from contaminants and also to force a turbulent air flow through the flowmeter throat.

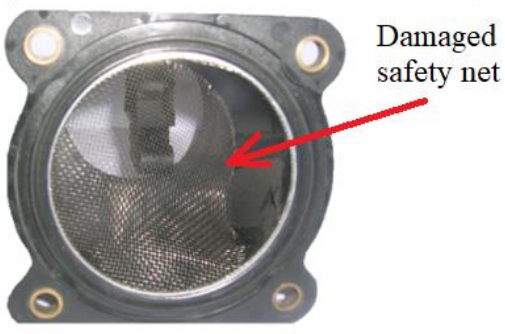

(a)

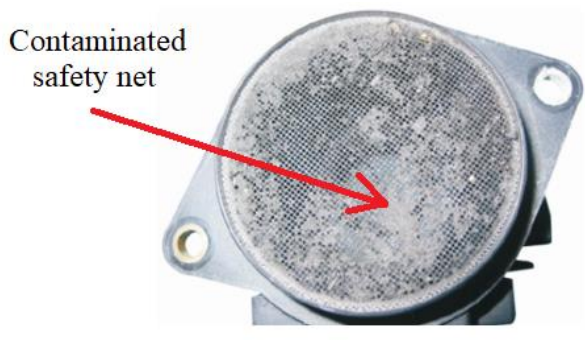

(b)

Figure 54. Protective mesh of flow meter with layered anemometer: (a) damaged, (b) contaminated with dust. The figure was made by the authors based on data from [153].

A view of the layered anemometer flow meter measuring element with mechanical damage caused by mineral dust grain impacts is shown in Figure 55.
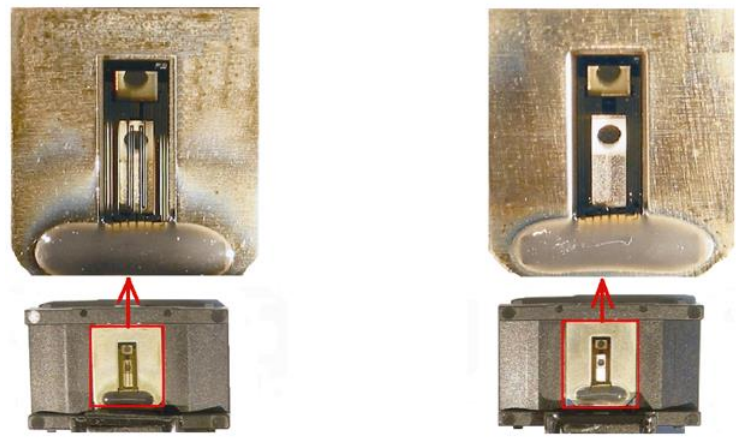

Figure 55. Mechanical damage to the measuring element of the layered anemometer flow meter due to impacts of mineral dust grains. Figure made by the authors using data from [153].

Salt found in the intake air and coming from the ground can also be deposited on the surface of the sensor layer, especially in winter (Figure 56).

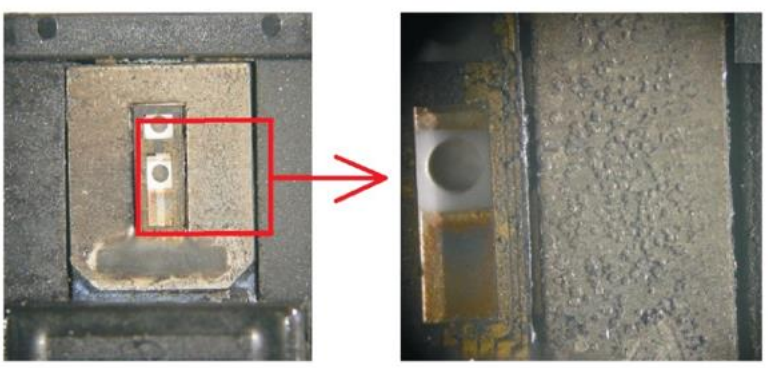

Figure 56. Salt contaminated flow meter sensor measurement element with layered anemometer. Figure made by the authors using data from [154].

Oil mist may settle on the gauge sensor (Figure 57). The presence of engine oil in the air stream (load) is a consequence of the crankcase ventilation system. The exhaust gases always contain a small amount of oil despite passing through the filtration system. If the oil separator of the ventilation system is damaged, the amount of incoming exhaust gas and thus oil is particularly high. The accumulation of such contaminants is generally 
caused by a backflow of the air stream in the direction from the head intake ducts to the air filter. This backflow is usually caused by pulsation of the air stream with insufficiently closed intake valves (or worn intake valves), through which the medium from the engine cylinders enters during the compression stroke.

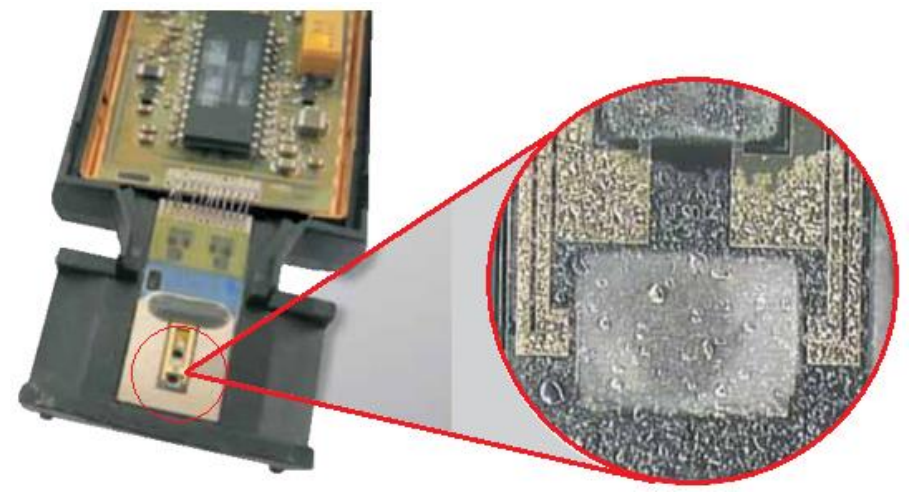

Figure 57. Oil-contaminated flow meter sensor measuring element with layered anemometer. Figure made by the authors using data from [153].

Deposition of this type of contamination is generally caused by backflow of the airflow in the direction from the head intake ducts to the air filter.

Figure 58 shows the results of laboratory testing of the $U_{w}=f\left(Q_{m}\right)$ characteristic of a Bosch HFM5 stratified air flow meter whose measuring element was contaminated with dust, followed by oil and dust. When the measuring element was contaminated with road dust there was an approximately $12 \%$ (Figure 58), drop in the output voltage $U_{w}$ over the entire range of air flow $Q_{m}$. In the case when the measuring element was contaminated with oil and dust, the drop in output voltage $U_{w}$ is much greater and for the maximum air flow $Q_{m}=526 \mathrm{~m}^{3} / \mathrm{h}$ is $50 \%$.

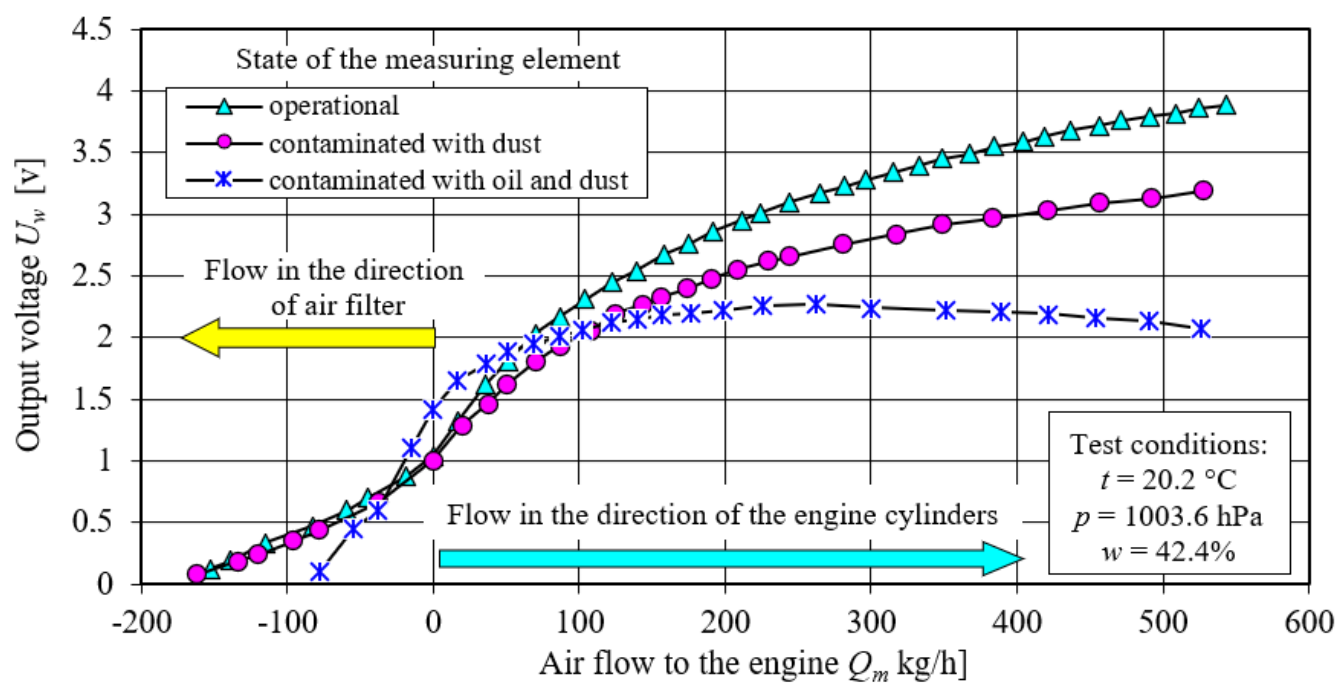

Figure 58. Characteristics $U_{w}=f\left(Q_{m}\right)$ of HFM5 layer flowmeter made by Bosch, used in Nissan cars, in working order and with the measuring element contaminated with dust.

Contamination of the flowmeter measuring element with road dust causes its isolation because silica $\mathrm{SiO}_{2}$, which is the main component of dust, is a good insulator both electrically and thermally. The layer of dust covering the measuring resistors is the cause of reduced intensity of their cooling, which results in lower value of the current needed to maintain a constant temperature difference between them. As a result, there is a decrease in the output voltage $U_{w}$ in relation to the output signal of the flowmeter in good condi- 
tion. The higher value of the voltage drop $U_{w}$ in the case of oil and dust contamination is probably due to a thicker layer of dust deposited on the measuring element, where oil acts as a binder.

In real engine operating conditions for lower values of output voltage $U_{w}$ the on-board computer reads lower values of the air flow and in order to maintain the appropriate composition of the mixture doses a smaller mass of fuel. As a result, the engine power decreases.

Dust grains which are sucked in together with the air have a destructive effect not only on the friction couples of the engine but also on the measuring element of the air flow meter. In the air supply system of the modern engine there is a turbocharger. The basic element of this device are two rotors connected by a shaft. Rotor located in the exhaust system of the engine acquires a rotational speed (about 240,000 rpm) from the exhaust stream, which is transferred to the rotor located in the inlet system of the engine. High velocities of the air stream flowing onto the compressor blades (50-80 m/s) and of the exhaust stream (over $300 \mathrm{~m} / \mathrm{s})$, high peripheral velocities of rotor units $(200-500 \mathrm{~m} / \mathrm{s})$ cause that the dust grains, upon contact with the surfaces of these elements, have significant kinetic energy which results in high impact force of the grains. This results in tearing out metal microparticles from the surface of the parts, violation of their surface structure and geometric shapes. The main effect of the impact of the dust grains on the rotor is the accelerated erosive wear of the rotor in the form of a change in geometry and deterioration of the smoothness of their surfaces and, consequently, a decrease in the efficiency and durability of the engine. The authors did not analyze this problem, as it is a topic for a separate article.

\section{Conclusions}

This paper provides a systematic review of the research progress in the field of the influence of engine intake air pollutants on the accelerated wear of the elements of the combination: piston, piston rings, cylinder (P-PR-CL) and plain bearing (journal-panel). Commonly harmful for internal combustion engines in operation is road dust, which enters the engine cylinders mainly with the intake air, causing accelerated wear, and thus reducing their reliability and durability. The main components of road dust are silica $\left(\mathrm{SiO}_{2}\right)$ and corundum $\mathrm{Al}_{2} \mathrm{O}_{3}$, whose proportion in dust reaches 60-95. The hardness of these components evaluated on the basis of the ten grade Mohs scale is 7 and 9, respectively, and significantly exceeds the hardness of construction materials used in engine construction.

Only $10-20 \%$ of the dust mass which enters the engine with the air through the intake system is deposited on the oil-coated cylinder liner walls. These are mineral dust grains with a size of less than $2-5 \mu \mathrm{m}$, as this is the accuracy provided by the cellulose-based filter materials commonly used. The dust together with the oil forms a kind of abrasive paste, which penetrates between the mating surfaces of the engine parts, e.g., piston-piston rings-cylinder wall, causing their abrasive wear.

As a result of the movement of the piston towards its bottom dead center (BTC) the rings scrape oil and contaminants from the cylinder floor into the oil sump. After reaching the lubrication system, the contaminants are distributed via the oil system to those tribological areas of the engine that are lubricated by oil and thus subject to accelerated wear. These include, for example, friction pairs: the "journal-cup" plain bearings of the crankshaft and camshaft, and the valve guide-valve stem assembly.

This paper presents an extensive analysis of the effect of three basic dust parameters (grain size and hardness and dust concentration in air) on the accelerated wear of the friction pair: piston, piston rings, cylinder (P-PR-CL) and plain bearing (journal-cup). It was pointed out that the wear values of the same component were obtained by different researchers using different testing techniques and under different conditions and evaluated by different indices. However, regardless of the different methodologies, the researchers' conclusions are similar. 
(1) The most dangerous for two mating parts are dust particles whose diameter $d_{p}$ is equal to the oil film thickness $h_{\text {min }}$ between two surfaces at a given moment. In an internal combustion engine, there are many mating parts lubricated by engine oil, where the oil film thickness depends on the conditions and parameters of engine operation and oil properties, and therefore takes on different values in the range $h_{\min }=0-50 \mu \mathrm{m}$;

(2) Abrasive wear of engine components is mainly caused by particles of 1-40 $\mu \mathrm{m}$, with dust grains of $1-20 \mu \mathrm{m}$ being the most dangerous. Grains smaller and larger than this range cause the same amount of wear;

(3) Depending on the type of association, its components experience maximum wear by a different range of particle sizes. It can be caused by different dynamic clearances between moving parts as well as different operating conditions and different measuring techniques;

(4) The upper piston ring and cylinder liner are most susceptible to abrasive wear. Maximum wear occurs at the top of the cylinder liner, in a plane perpendicular to the crankshaft axis, where the ring reaches TDC. This is due to the particularly unfavorable conditions for liner-ring interaction at this point: high temperature (oil viscosity drop) and low piston speed, the effect of normal force on the cylinder walls is greatest, high pressure of exhaust gases on the rear wall of the rings. As a result, the value of the oil film decreases significantly or disappears completely. This is the reason for the occurrence of boundary friction and increased wear.

However, more reliable tests of wear of engine elements are those carried out during experimental bench tests or during operation of engines in real car exploitation. Such research is labor-consuming and expensive; hence, the number of research results in the literature is insignificant. Excessive wear of the P-PR-CL junction elements causes several unfavorable phenomena in engine operation. First, there is increased blowing of the compressed charge and hot exhaust gases into the crankcase. As a result, the pressure decreases at the end of the compression stroke, and as a consequence, the torque and power of the engine decrease and the specific fuel consumption increases. Increased blow-by of hot exhaust gases into the oil sump causes an increase in the temperature of the P-PR-CL bonding elements and the oil, which in turn lowers its viscosity. As a result, the thickness of the oil film decreases, and consumption increases. This phenomenon becomes particularly important when the piston is located near TDC, where the conditions of oil film formation, due to low piston speed, high temperature and high load, are extremely unfavorable. In addition, hot exhaust gases containing soot and other contaminants flow into the crankcase and adversely affect (degrade) the oil there.

An inherent phenomenon of complicated piston ring movements during their operation is pumping oil over the piston bottom into the combustion chamber. The burning oil increases the emission of toxic exhaust components. It should be noted that blow-through of compressed cargo and exhaust gases to the crankcase occurs in every engine, but with the mileage of the vehicle and the progressive wear of the P-PR-CL combination elements, this phenomenon increases and may have an impact on the increased emission of toxic components of exhaust gases.

The unfavorable phenomenon of friction and wear of friction components of an engine, resulting mainly from the presence of dust, is an inherent process of car engine operation. This phenomenon can be minimized by:

- $\quad$ use of filtration materials with the use of nanofibers, which increase the effectiveness and accuracy of engine inlet air filtration-grains above $1 \mu \mathrm{m}$,

- use of wear-resistant ring and cylinder surfaces by spraying

- Texturing of ring and cylinder surfaces,

- use of suitable lubricating oils and fuels.

Dust in the air drawn into the engine is trapped and deposited on the measuring element of the air mass sensor. Other contaminants (moisture, salt, oil) also settle on this element, but dust grains are particularly dangerous due to their hardness and sharp edges. Firstly, the deposited layer of dust is mainly silica, which is a good insulator and 
deteriorates the heat exchange between the measuring element material and the flowing air, which is the essence of the flow meter operation. The voltage generated by the flowmeter then has a lower value than an efficient flowmeter, which the computer reads as a smaller mass of air and dispenses a smaller mass of fuel. As a result, engine power decreases. In addition, dust grains coming in at high speed scratch the surface of the airflow meter's heating wire and reduce its life, which combined with vibrations from the engine can cause it to break.

Author Contributions: Conceptualization, T.D.; methodology, T.D.; software, T.D. and S.D.D.; validation, T.D. and S.D.D.; formal analysis, T.D. and S.D.D.; investigation, T.D. and S.D.D.; resources, T.D.; data curation, T.D.; writing - original draft preparation, T.D. and S.D.D. All authors have read and agreed to the published version of the manuscript.

Funding: This research received no external funding.

Institutional Review Board Statement: Not applicable.

Informed Consent Statement: Not applicable.

Data Availability Statement: Data is contained within the article.

Conflicts of Interest: The authors declare no conflict of interest.

\section{References}

1. Nikas, G.K. A state-of-the-art review on the effects of particulate contamination and related topics in machine-element contacts. Proc. Inst. Mech. Eng. Part J J. Eng. Tribol. 2010, 224, 453-479. [CrossRef]

2. Shang, X.; Lee, M.; Lim, S.; Gustafsson, Ö.; Lee, G.; Chang, L. Dust Criteria Derived from Long-Term Filter and Online Observations at Gosan in South Korea. Atmosphere 2021, 12, 1419. [CrossRef]

3. Chun, Y.; Kim, J.; Choi, J.C.; Boo, K.O.; Oh, S.N.; Lee, M. Characteristic number size distribution of aerosol during Asian dust period in Korea. Atmos. Environ. 2001, 35, 2715-2721. [CrossRef]

4. Luo, H.; Zhou, W.; Jiskani, I.M.; Wang, Z. Analyzing Characteristics of Particulate Matter Pollution in Open-Pit Coal Mines: Implications for Green Mining. Energies 2021, 14, 2680. [CrossRef]

5. Csavina, J.; Field, J.; Taylor, M.P.; Gao, S.; Landázuri, A.; Betterton, E.A.; Sáez, A.E. A review on the importance of metals and metalloids in atmospheric dust and aerosol from mining operations. Sci. Total Environ. 2012, 433, 58-73. [CrossRef]

6. Li, L.; Zhang, R.; Sun, J.; He, Q.; Kong, L.; Liu, X. Monitoring and prediction of dust concentration in an open-pit mine using a deep-learning algorithm. J. Environ. Health Sci. Eng. 2021, 19, 401-414. [CrossRef] [PubMed]

7. Baddocka, M.C.; Zobeck, T.M.; Scot Van Pelt, R.; Fredrickson, E.L. Dust emissions from undisturbed and disturbed, crusted playa surfaces: Cattle trampling effects. Aeolian Res. 2011, 3, 31-41. [CrossRef]

8. Norman, M.; Sundvor, I.; Denby, B.R.; Johansson, C.; Gustafsson, M.; Blomqvist, G.; Janhäll, S. Modelling road dust emission abatement measures using the NORTRIP model: Vehicle speed and studded tyre reduction. Atmos. Environ. 2016, 134, 96-108. [CrossRef]

9. Rivera, B.H.; Rodriguez, M.G. Characterization of Airborne Particles Collected from Car Engine Air Filters Using SEM and EDX Techniques. Int. J. Environ. Res. Public Health 2016, 13, 985. [CrossRef]

10. Chan, D.; Stachowiak, G.W. Review of automotive brake friction materials. Proc. Inst. Mech. Eng. Part D J. Automob. Eng. 2004, 218, 953-966. [CrossRef]

11. Haider, A.; Haider, S.; Kang, I.K. A comprehensive review summarizing the effect of electrospinning parameters and potential applications of nanofibers in biomedical and biotechnology. Arab. J. Chem. 2018, 11, 1165-1188. [CrossRef]

12. Thorpe, A.; Harrison, R.H. Sources and properties of non-exhaust particulate matter from road traffic: A review. Sci. Total Environ. 2008, 400, 270-282. [CrossRef]

13. Barr, B.C.; Andradóttir, H.Ó.; Thorsteinsson, T.; Erlingsson, S. Mitigation of Suspendable Road Dust in a Subpolar, Oceanic Climate. Sustainability 2021, 13, 9607. [CrossRef]

14. Kreider, M.L.; Panko, J.M.; McAtee, B.L.; Sweet, L.I.; Finley, B.L. Physical and chemical characterization of tire-related particles: Comparison of particles generated using different methodologies. Sci. Total Environ. 2010, 408, 652-659. [CrossRef]

15. Kupiainen, K.J.; Tervahattu, H.; Räisänen, M.; Mäkelä, T.; Aurela, M.; Hillamo, R. Size and composition of airborne particles from pavement wear, tires, and traction sanding. Environ. Sci. Technol. 2005, 39, 699-706. [CrossRef] [PubMed]

16. Panko, J.; Kreider, M.; Unice, K. Review of tire wear emissions: A review of tire emission measurement studies: Identification of gaps and future needs. In Non-Exhaust Emissions; Elsevier: Amsterdam, The Netherlands, 2018; Chapter 7; pp. 147-160. [CrossRef]

17. Oroumiyeh, F.; Zhu, Y. Brake and tire particles measured from on-road vehicles: Effects of vehicle mass and braking intensity. Atmos. Environ. X 2021, 12, 100121. [CrossRef] 
18. Kovochich, M.; Parker, J.A.; Oh, S.C.; Lee, J.P.; Wagner, S.; Reemtsma, T.; Unice, K.M. Characterization of Individual Tire and Road Wear Particles in Environmental Road Dust, Tunnel Dust, and Sediment. Environ. Sci. Technol. Lett. 2021, 8, 1057-1064. [CrossRef]

19. Merkisz, J.; Pielecha, J.; Radzimirski, S. Emisja Zanieczyszczeń Motoryzacyjnych w Świecie Nowych Przepisów Unii Europejskiej; WKŁ: Warszawa, Poland, 2012. (In Polish)

20. Mrozik, M.; Merkisz-Guranowska, A. Environmental Assessment of the Vehicle Operation Process. Energies 2020, $14,76$. [CrossRef]

21. Lähde, T.; Giechaskiel, B.; Pavlovic, J.; Suarez-Bertoa, R.; Valverde, V.; Clairotte, M.; Martini, G. Solid particle number emissions of 56 light-duty Euro 5 and Euro 6 vehicles. J. Aerosol Sci. 2022, 159, 105873. [CrossRef]

22. Giechaskiel, B.; Woodburn, J.; Szczotka, A.; Bielaczyc, P. Particulate Matter (PM) Emissions of Euro 5 and Euro 6 Vehicles Using Systems with Evaporation Tube or Catalytic Stripper and $23 \mathrm{~nm}$ or $10 \mathrm{~nm}$ Counters; SAE International: Warrendale, PA, USA, 2020. [CrossRef]

23. Muthu, M.; Gopal, J.; Kim, D.-H.; Sivanesan, I. Reviewing the Impact of Vehicular Pollution on Road-Side Plants-Future Perspectives. Sustainability 2021, 13, 5114. [CrossRef]

24. Zhao, J.; Peng, P.; Song, J.; Ma, S.; Sheng, G.; Fu, J. Research on flux of dry atmospheric falling dust and its characterization in a subtropical city, Guangzhou, South China. Air Quality. Atmos. Health 2010, 3, 139-147. [CrossRef]

25. Smialek, J.L.; Archer, F.A.; Garlick, R.G. Turbine Airfoil Degradation in the Persian Gulf War. JOM 1994, 46, 39-40. [CrossRef]

26. Dzierżanowski, P.; Kordziński, W.; Otyś, J.; Szczeciński, S.; Wiatrek, R. Napędy Lotnicze. Turbinowe Silniki Śmigłowe i Śmigłowcowe; WKŁ: Warszawa, Poland, 1985. (In Polish)

27. Cardozo, J.I.H.; Sánchez, D.F.P. An experimental and numerical study of air pollution near unpaved Roads. Air Qual. Atmos. Health 2019, 12, 471-489. [CrossRef]

28. Rienda, I.C.; Alves, C.A. Road dust resuspension: A review. Atmos. Res. 2021, 261, 105740. [CrossRef]

29. Fujiwara, F.; Rebagliati, R.J.; Dawidowski, L.; Gómez, D.; Polla, G.; Pereyra, V.; Smichowski, P. Spatial and chemical patterns of size fractionated road dust collected in a megacitiy. Atmos. Environ. 2011, 45, 1497-1505. [CrossRef]

30. Schaeffer, J.W.; Olson, L.M. Air Filtration Media for Transportation Applications. Filtr. Sep. 1998, 35, $124-129$.

31. Elis, M.; Bojdo, N.; Covey-Crump, S.; Jones, M.; Filippone, A.; Pawley, A. Generalized Predictions of Particle-Vane Retention Probability in Gas Turbine Engines. J. Turbomach. 2021, 143, 111008. [CrossRef]

32. Jaroszczyk, T.; Pardue, B.A.; Heckel, S.P.; Kallsen, K.J. Engine air cleaner filtration performance-Theoretical and experimental background of testing. In Proceedings of the AFS Fourteenth Annual Technical Conference and Exposition, Tampa, FL, USA, 1 May 2001.

33. Pinnick, R.G.; Fernandez, G.; Hinds, B.D.; Bruce, C.W.; Schaefer, K.W.; Pendelton, J.D. Dust Generated by Vehicular Traffic on Unpaved Roadways: Sizes and Infrared Extinction Characteristics. Aerosol Sci. Technol. 1985, 4, 99-121. [CrossRef]

34. Barbolini, M.; Di Pauli, F.; Traina, M. Simulation der luftfiltration zur auslegung von filterelementen. MTZ-Mot. Z. 2014, 5, 52-57. [CrossRef]

35. De Fré, R.; Bruynseraede, P.; Kretzschmar, J.G. Air pollution measurements in traffic tunnels. Environ. Health Perspect. 1994, 102 (Suppl. S4), 31-37. [CrossRef] [PubMed]

36. Dziubak, T. Zapylenie powietrza wokół pojazdu terenowego. Wojsk. Przegląd Tech. 1990, 3, 154-157. (In Polish)

37. Burda, S.; Chodnikiewicz, Z. Konstrukcja i badania pyłowe filtrów powietrza silnika czołgowego. Bull. Mil. Univ. Technol. 1962, 3, 12-34. (In Polish)

38. Szczepankowski, A.; Szymczak, J.; Przysowa, R. The Effect of a Dusty Environment Upon Performance and Operating Parameters of Aircraft Gas Turbine Engines. Available online: https://www.sto.nato.int/publications/STO\%20Meeting\%20Proceedings/ STO-MP-AVT-272/MP-AVT-272-18P.pdf (accessed on 2 January 2022).

39. Ptak, T.J.; Fallon, S.L. Particulate Concentration In Automobile Passenger Compartments. Part. Sci. Technol. 1994, 12, 313-322. [CrossRef]

40. Long, J.; Tang, M.; Sun, Z.; Liang, Y.; Hu, J. Dust Loading Performance of a Novel Submicro-Fiber Composite Filter Medium for Engine. Materials 2018, 11, 17. [CrossRef]

41. Bojdo, N.; Filipone, A. Effect of desert particulate composition on helicopter engine degradation rate. In Proceedings of the 40th European Rotorcraft Forum, Southampton, UK, 2-5 September 2014. [CrossRef]

42. Wróblewski, P. Effect of asymmetric elliptical shapes of the sealing ring sliding surface on the main parameters of the oil film. Combust. Engines 2017, 168, 84-93. [CrossRef]

43. Wróblewski, P.; Iskra, A. Problems of Reducing Friction Losses of a Piston-Ring-Cylinder Configuration in a Combustion Piston Engine with an Increased Isochoric Pressure Gain. In Proceedings of the SAE Powertrains, Fuels \& Lubricants Meeting, Online, 22-24 September 2020; SAE Technical Paper 2020-01-2227; SAE International: Warrendale, PA, USA, 2020. [CrossRef]

44. Woś, P.; Michalski, J. Effect of Initial Cylinder Liner Honing Surface Roughness on Aircraft Piston Engine Performances. Tribol. Lett. 2011, 41, 555-567. [CrossRef]

45. Koszałka, G.; Suchecki, A. Changes in performance and wear of small diesel engine during durability test. Combust. Engines 2015, 162, 34-40. [CrossRef]

46. Koszałka, G.; Suchecki, A. Changes in blow-by and compression pressure of a diesel engine during a bench durability test. Combust. Engines 2013, 154, 34-39. [CrossRef] 
47. Wróblewski, P. Analysis of Torque Waveforms in Two-Cylinder Engines for Ultralight Aircraft Propulsion Operating on 0W-8 and 0W-16 Oils at High Thermal Loads Using the Diamond-Like Carbon Composite Coating. SAE Int. J. Engines 2022, 15, 129-146. [CrossRef]

48. Rao, X.; Sheng, C.; Guo, Z. The Influence of Different Surface Textures on Wears in Cylinder Liner Piston Rings. Surf. Topogr. Metrol. Prop. 2019, 7, 045011. [CrossRef]

49. Meng, Y.; Xu, J.; Jin, Z.; Prakash, B.; Hu, Y. A review of recent advances in tribology. Friction 2020, 8, 221-300. [CrossRef]

50. Ferreira, R.; Martins, J.; Carvalho, O.; Sobral, L.; Carvalho, S.; Silva, F. Tribological solutions for engine piston ring surfaces: An overview on the materials and manufacturing. Mater. Manuf. Process. 2020, 35, 498-520. [CrossRef]

51. Biberger, J.; Füßer, H.-J. Development of a test method for a realistic, single parameter-dependent analysis of piston ring versus cylinder liner contacts with a rotational tribometer. Tribol. Int. 2017, 113, 111-124. [CrossRef]

52. Priest, M.; Dowson, D.; Taylor, C.M. Predictive wear modelling of lubricated piston rings in a diesel engine. Wear 1999, 231, 89-101. [CrossRef]

53. Zabala, B.; Igartua, A.; Fernández, X.; Priestner, C.; Ofner, H.; Knaus, O.; Nevshupa, R. Friction and wear of a piston ring/cylinder liner at the top dead centre: Experimental study and modelling. Tribol. Int. 2017, 106, 23-33. [CrossRef]

54. Delprete, C.; Razavykia, A. Piston ring-liner lubrication and tribological performance evaluation: A review. Proc. Inst. Mech. Eng. Part J J. Eng. Tribol. 2017, 232, 193-209. [CrossRef]

55. Etsion, I.; Sher, E. Improving fuel efficiency with laser surface textured piston rings. Tribol. Int. 2009, 42, 542-547. [CrossRef]

56. Meng, X.; Gu, C.; Zhang, D. Modeling the wear process of the ring/liner conjunction considering the evaluation of asperity height distribution. Tribol. Int. 2017, 112, 20-32. [CrossRef]

57. Michelberger, B.; Jaitner, D.; Hagel, A.; Striemann, P.; Kröger, B.; Leson, A.; Lasagni, A.F. Combined measurement and simulation of piston ring cylinder liner contacts with a reciprocating long-stroke tribometer. Tribol. Int. 2021, 163, 107146. [CrossRef]

58. Trivedi, H.K.; Bhatt, D.V. Effect of Lubricating Oil on Tribological behaviour in Pin on Disc Test Rig. Tribol. Ind. 2017, 39, 90-99. [CrossRef]

59. Reitz, R.D.; Ogawa, H.; Payri, R.; Fansler, T.; Kokjohn, S.; Moriyoshi, Y.; Agarwal, A.; Arcoumanis, D.; Assanis, D.; Bae, C.; et al IJER editorial: The future of the internal combustion engine. Int. J. Engine Res. 2020, 21, 3-10. [CrossRef]

60. Grabon, W.; Pawlus, P.; Wos, S.; Koszela, W.; Wieczorowski, M. Effects of cylinder liner surface topography on friction and wear of liner-ring system at low temperature. Tribol. Int. 2018, 121, 148-160. [CrossRef]

61. Indudhar, M.R.; Banapurmath, N.R.; Rajulu, K.G.; Patil, A.Y.; Javed, S.; Khan, T.M.Y. Optimization of Piston Grooves, Bridges on Cylinder Head, and Inlet Valve Masking of Home-Fueled Diesel Engine by Response Surface Methodology. Sustainability 2021, 13, 11411. [CrossRef]

62. Di Blasio, G.; Ianniello, R.; Beatrice, C. Hydrotreated vegetable oil as enabler for high-efficient and ultra-low emission vehicles in the view of 2030 targets. Fuel 2021, 310, 122206. [CrossRef]

63. Agarwal, A.K.; Dhar, A.; Gupta, J.G.; Kim, W.I.; Choi, K.; Lee, C.S.; Park, S. Effect of fuel injection pressure and injection timing of Karanja biodiesel blends on fuel spray, engine performance, emissions and combustion characteristics. Energy Convers. Manag. 2015, 91, 302-314. [CrossRef]

64. Kim, M.-S.; Akpudo, U.E.; Hur, J.-W. A Study on Water-Induced Damage Severity on Diesel Engine Injection System Using Emulsified Diesel Fuels. Electronics 2021, 10, 2285. [CrossRef]

65. Su, Y.; Zhang, Y.; Xie, F.; Duan, J.; Li, X.; Liu, Y. Influence of ethanol blending ratios on in-cylinder soot processes and particulate matter emissions in an optical direct injection spark ignition engine. Fuel 2022, 308, 121944. [CrossRef]

66. Mujtaba, M.A.; Masjuki, H.H.; Kalam, M.A.; Noor, F.; Farooq, M.; Ong, H.C.; Gul, M.; Soudagar, M.E.M.; Bashir, S.; Rizwanul Fattah, I.M.; et al. Effect of Additivized Biodiesel Blends on Diesel Engine Performance, Emission, Tribological Characteristics, and Lubricant Tribology. Energies 2020, 13, 3375. [CrossRef]

67. Karczewski, M.; Szczech, L. Influence of the F-34 unified battlefield fuel with bio components on usable parameters of the IC engine. Eksploat. Niezawodn.-Maint. Reliab. 2016, 18, 358-366. [CrossRef]

68. Rimkus, A.; Vipartas, T.; Matijošius, J.; Stravinskas, S.; Kriaučiunas, D. Study of Indicators of CI Engine Running on Conventional Diesel and Chicken Fat Mixtures Changing EGR. Appl. Sci. 2021, 11, 1411. [CrossRef]

69. Agarwal, D.; Singh, S.K.; Agarwal, A.K. Effect of Exhaust Gas Recirculation (EGR) on performance, emissions, deposits and durability of a constant speed compression ignition engine. Appl. Energy 2011, 88, 2900-2907. [CrossRef]

70. Duan, X.; Liu, Y.; Liu, J.; Lai, M.-C.; Jansons, M.; Guo, G.; Zhang, S.; Tang, Q. Experimental and numerical investigation of the effects of low-pressure, high-pressure and internal EGR configurations on the performance, combustion and emission characteristics in a hydrogen-enriched heavy-duty lean-burn natural gas SI engine. Energy Convers. Manag. 2019, 195, 1319-1333. [CrossRef]

71. George, S.; Balla, S.; Gautam, M. Effect of diesel soot contaminated oil on engine wear. Wear 2007, 262, 1113-1122. [CrossRef]

72. Oungpakornkaew, P.; Karin, P.; Tongsri, R.; Hanamura, K. Characterization of biodiesel and soot contamination on four-ball wear mechanisms using electron microscopy and confocal laser scanning microscopy. Wear 2020, 458-459, 203407. [CrossRef]

73. Al Sheikh Omar, A.; Motamen Salehi, F.; Farooq, U.; Morina, A.; Neville, A. Chemical and physical assessment of engine oils degradation and additive depletion by soot. Tribol. Int. 2021, 160, 107054. [CrossRef]

74. Matarrese, R. Catalytic Materials for Gasoline Particulate Filters Soot Oxidation. Catalysts 2021, 11, 890. [CrossRef] 
75. Awad, O.I.; Ma, X.; Kamil, M.; Ali, O.M.; Zhang, Z.; Shuai, S. Particulate emissions from gasoline direct injection engines: A review of how current emission regulations are being met by automobile manufacturers. Sci. Total Environ. 2020, 718, 137302. [CrossRef]

76. Durst, M.; Klein, G.; Moser, N. Filtration in Fahrzeugen; Mann+Hummel GMBH: Ludwigsburg, Germany, 2005.

77. Maddineni, A.K.; Das, D.; Damodaran, R.M. Numerical investigation of pressure and flow characteristics of pleated air filter system for automotive engine intake application. Sep. Purif. Technol. 2019, 212, 126-134. [CrossRef]

78. Halim, M.A.A.; Mohd, N.A.R.N.; Nasir, M.N.M.; Dahalan, M.N. Experimental and Numerical Analysis of a Motorcycle Air Intake System Aerodynamics and Performance. Int. J. Automot. Eng. 2020, 17, 7607-7617.

79. Kaźmierczak, A.; Tkaczyk, M. Team durability test of a 1.3 MW locomotive diesel engine with prototype piston rings. Combust. Engines 2021, 187, 77-82. [CrossRef]

80. Schäffer, J.; Wachtmeister, G. Analyse der Kolbengruppenreibung und -schmierung von Ottomotoren-Die Bedeutung des Ölabstreifrings. Forsch. Ing. 2021, 4, 1065-1075. [CrossRef]

81. Avis, M. Particles: Friend or Foe? Understanding the Value of Particles in Oil Analysis-Machinery Lubrication 6. Available online: https: / / www.machinerylubrication.com/Read/28974/particles-friend-foe (accessed on 2 January 2022).

82. Fitch, J. Clean Oil Reduces Engine Fuel Consumption-Practicing Oil Analysis Magazine. Available online: https://www. machinerylubrication.com/Read/401/oil-engine-fuel-consumption. (accessed on 2 January 2022).

83. McClelland, J.E.; Billett, S.M. Filter Life versus Engine Wear. SAE Trans. 1966, 74, 922-936.

84. Gupta, N.; Singh, S.K.; Pandey, S.M. Tribological characterisation of thermal sprayed CrC alloyed coating-A review. Adv. Mater. Process. Technol. 2020, 7, 660-683. [CrossRef]

85. Ali, M.K.A.; Xianjun, H.; Turkson, F.R.; Ezzat, M. An analytical study of tribological parameters between piston ring and cylinder liner in internal combustion engines. Proc. Inst. Mech. Eng. Part K J. Multi-Body Dyn. 2016, 230, 329-349. [CrossRef]

86. Fatjo, G.G.A.; Smith, E.H.; Sherrington, I. Piston-ring film thickness: Theory and experiment compared. Proc. Inst. Mech. Eng. Part J J. Eng. Tribol. 2017, 232, 550-567. [CrossRef]

87. Needelman, W.M.; Madhavan, P.M. Review of Lubricant Contamination and Diesel Engine Wear-SAE Technical Paper Series 881827. In Proceedings of the Truck and Bus Meeting and Exposition, Indianapolis, IN, USA, 7-10 November 1988.

88. Grafe, T.; Gogins, M.; Barris, M.; Schaefer, J.; Canepa, R. Nanofibers in filtration applications in transportation, filtration. In Proceedings of the International Conference and Exposition, Chicago, IL, USA, 3-5 December 2001.

89. Kosmider, K.; Scott, J. Polymeric Nanofibres Exhibit an Enhanced Air Filtration Performance. Filtr. Sep. 2002, 39, 20-22. [CrossRef]

90. Wei, L.; Qin, X. Nanofiber bundles and nanofiber yarn device and their mechanical properties: A review. Text. Res. J. 2016, 86, 1885-1898. [CrossRef]

91. Leung, W.W.F.; Hau, C.W.Y.; Choy, H.F. Microfiber-nanofiber composite filter for high-efficiency and low pressure drop under nano-aerosol loading. Sep. Purif. Technol. 2018, 206, 26-38. [CrossRef]

92. Schmid, B.; Kreiner, A.; Poljak, I.; Klein, G.M. Luftfilter Mit Nanofaserbeschichtungen. MTZ-Mot. Z. 2012, 73, 592-597. [CrossRef]

93. Jaroszczyk, T. Air filtration in heavy-duty motor vehicle applications. In Proceedings of the Dust Symposium III, Vicksburg, MS, USA, 15-17 September 1987.

94. Nagy, J. Filtrowanie a żywotność silnika. Siln. Spalinowe 1973, 3, 43-47. (In Polish)

95. Jaroszczyk, T.; Fallon, S.L.; Liu, Z.G.; Heckel, S.P. Development of a Method to Measure Engine Air Cleaner Fractional Efficiency; SAE Technical Paper 1999-01-0002; SAE International: Warrendale, PA, USA, 1999.

96. Watson, C.E.; Hanly, F.J.; Burchell, R.W. Abrasive Wear of Piston Rings. SAE Trans. 1955, 63, 717-728.

97. Borawska, I. Papierowe przegrody filtracyjne-Własności, metody badań i zastosowanie. In Proceedings of the I Ogólnopolska Konferencja Naukowo-Techniczna: Filtry i Filtracja Płynów, Rzeszów, Poland, October 1974. (In Polish)

98. Thomas, G.E.; Culbert, R.M. Ingested dust, filters, and diesel engine ring wear. In Proceedings of the National West Coast Meeting, San Francisco, CA, USA, 12-15 August 1968; Society Of Automotive Engineers, Inc.: Warrendale, PA, USA, 1968. Available online: https:/ / saemobilus.sae.org/content/680536/ (accessed on 29 December 2021).

99. Addison, J.A.; Needelman, W.M. Diesel Engine Lubricant Contamination and Wear; Scientific and Laboratory Services Department; Pall Corporation: Glen Cove, NY, USA, 1986. Available online: https://p2infohouse.org/ref/31/30453.pdf (accessed on 5 November 2021).

100. Jones, G.W.; Eleftherakis, J.G. Correlating Engine Wear with Filter Multipass Testing; SAE Technical Paper Series; SAE International: Warrendale, PA, USA, 1995. [CrossRef]

101. Treuhaft, M.B. The Use of Radioactive Tracer Technology to Measure Engine Ring Wear in Response to Dust Ingestion; SAE Technical Paper Series; SAE International: Warrendale, PA, USA, 1993. [CrossRef]

102. Milder, F.L.; Armini, A.J.; Jones, G.W. The Use of Surface Layer Activation Wear Monitoring for Filter Design and Evaluation; SAE Technical Paper Series; SAE International: Warrendale, PA, USA, 1981. [CrossRef]

103. Alfadhli, A.; Alazemi, A.; Khorshid, E. Numerical minimisation of abrasive-dust wear in internal combustion engines. Int. J. Surf. Sci. Eng. 2020, 14, 68-88. [CrossRef]

104. Eckardt, C. Einflu $\beta$ von Fremdkörpern im Schmiermittel auf das Betriebsverhalten von Motorengleitlagern. MTZ-Mot. Z. 1983, $44,393-401$. 
105. Khorshid, E.A.; Nawwar, A.M. A review of the effect of sand dust and filtration on automobile engine wear. Wear 1991, 141, 349-371. [CrossRef]

106. Barris, M.A. Total Filtration ${ }^{\mathrm{TM}}$ : The Influence of Filter Selection on Engine Wear, Emissions, and Performance; SAE Technical Paper Series 952557; SAE International: Warrendale, PA, USA, 1995.

107. Ptak, T.J.; Richberg, P.; Vasseur, T. Discriminating Tests for Automotive Engine Air Filters; SAE Technical Paper Series; SAE International: Warrendale, PA, USA, 2001. [CrossRef]

108. Łysoń, F.; Siwula, Z. Analiza konstrukcji filtrów powietrza do tłokowych silników spalinowych. In Proceedings of the Materiały I Ogólnokrajowej Konferencji Naukowo-Technicznej: Filtry i Filtracja Płynów, Rzeszów, Poland, October 1974. (In Polish).

109. Truhan, J. Filter Performance as the Engine Sees It. Filtr. Sep. 1997, 34, 1019-1022.

110. Slabov, E.; Antropov, B.; Nilov, V. Influence of Air Quality on Engine Life. Automobile Transport. 1978, 4, 41-42.

111. Ruzaev, I.G.; Strykowski, F.R. Investigation of the Combined Engine Air Purification System. Automotive Industry. 1979, 8, 8-10.

112. Dziubak, T.; Wysocki, T. Analiza Wpływu Konstrukcji Wkładu Filtra Powietrza na Wystapienie Uszkodzeń w Postaci Zarysowań Wzdłużnych Gładzi Tulei Cylindrowych w Silniku Ciagnika Siodłowego MAN F19. Opinia Techniczna; WAT: Warszawa, Poland, 2009. (In Polish)

113. Dziubak, T.; Dziubak, S.D. Experimental Study of Filtration Materials Used in the Car Air Intake. Materials 2020, $13,3498$. [CrossRef] [PubMed]

114. Saraiev, O.; Khrulev, A. Devising a model of the airflow with dust particles in the intake system of a vehicle's internal combustion engine. East.-Eur. J. Enterp. Technol. 2021, 2, 61-69. [CrossRef]

115. Khrulev, A.E.; Dmitriev, S.A. Influence of the inlet system design on dust centrifugation and the parts wear of the modern internal combustion engines. Intern. Combust. Engines 2020, 2, 73-84. [CrossRef]

116. Al-Rousan, A.A. Effect of dust and sulfur content on the rate of wear of diesel engines working in the Jordanian desert. Alex. Eng. J. 2006, 45, 527-536.

117. Michalski, J.; Woś, P. The effect of cylinder liner surface topography on abrasive wear of piston-cylinder assembly in combustion engine. Wear 2011, 271, 582-589. [CrossRef]

118. Xu, Y.; Zhang, X.; Hao, X.; Teng, D.; Zhao, T.; Zeng, Y. Micro/nanofibrous nonwovens with high filtration performance and radiative heat dissipation property for personal protective face mask. Chem. Eng. J. 2021, 423, 130175. [CrossRef]

119. Deng, Y.; Lu, T.; Cui, J.; Samal, S.K.; Xiong, R.; Huang, C. Bio-based electrospun nanofiber as building blocks for a novel eco-friendly air filtration membrane: A review. Sep. Purif. Technol. 2021, 277, 119623. [CrossRef]

120. Li, Y.; Yin, X.; Yu, J.; Ding, B. Electrospun nanofibers for high-performance air filtration. Compos. Commun. 2019, 15, 6-19. [CrossRef]

121. Sofi, H.S.; Rashid, R.; Amna, T.; Hamid, R.; Sheikh, F.A. Recent advances in formulating electrospun nanofiber membranes: Delivering active phytoconstituents. J. Drug Deliv. Sci. Technol. 2020,60, 102038. [CrossRef]

122. Malviya, R.M. Nano-Fiber Filters for Automotive Applications; SAE Technical Paper Series; SAE International: Warrendale, PA, USA, 2018. [CrossRef]

123. Zhu, W.H.; Poudyal, A.; Martin, P.M.; Tatarchuk, B.J. Characterization of Dirt Holding Capacity of Microfiber-Based Filter Media Using Thermal Impedance Spectroscopy. ACS Appl. Mater. Interfaces 2020, 12, 15737-15747. [CrossRef]

124. Graham, K.; Ouyang, M.; Raether, T.; Grafe, T.; Mc Donald, B.; Knauf, P. Polymeric Nanofibers in Air Filtration Applications. In Proceedings of the 5th Annual Technical Conference \& Expo of the American Filtration \& Separations Society, Galveston, TX, USA, 9-12 April 2002.

125. Technologia Medium Ultra-Web. Available online: https://www.donaldson.com/pl-pl/industrial-dust-fume-mist/technicalarticles/ultra-web-media-technology/ (accessed on 24 January 2022).

126. Zhang, H.; Xie, Y.; Song, Y.; Qin, X. Preparation of high-temperature resistant poly (m-phenylene isophthalamide)/polyacrylonitrile composite nanofibers membrane for air filtration. Colloids Surf. A Physicochem. Eng. Asp. 2021, 624, 126831. [CrossRef]

127. Jaroszczyk, T.; Fallon, S.L.; Schwartz, S.W. Development Of High Dust Capacity, High Efficiency Engine Air Filter With Nanofibers. J. KONES Powertrain Transp. 2008, 15, 215-224.

128. Wróblewski, P.; Koszalka, G. An Experimental Study on Frictional Losses of Coated Piston Rings with Symmetric and Asymmetric Geometry. SAE Int. J. Engines 2021, 14, 853-866. [CrossRef]

129. Wróblewski, P.; Rogólski, R. Experimental Analysis of the Influence of the Application of TiN, TiAlN, CrN and DLC1 Coatings on the Friction Losses in an Aviation Internal Combustion Engine Intended for the Propulsion of Ultralight Aircraft. Materials 2021, 14, 6839. [CrossRef] [PubMed]

130. Wróblewski, P. Technology for Obtaining Asymmetries of Stereometric Shapes of the Sealing Rings Sliding Surfaces for Selected Anti-Wear Coatings. In Proceedings of the SAE Powertrains, Fuels \& Lubricants Meeting, Online, 22-24 September 2020; SAE Technical Paper 2020-01-2229. SAE International: Warrendale, PA, USA, 2020. [CrossRef]

131. Dolatabadi, N.; Forder, M.; Morris, N.; Rahmani, R.; Rahnejat, H.; Howell-Smith, S. Influence of advanced cylinder coatings on vehicular fuel economy and emissions in piston compression ring conjunction. Appl. Energy 2020, 259, 114129. [CrossRef]

132. Ficici, F.; Kurgun, S. Analysis of Weight loss in Reciprocating Wear Test of Cylinder Liner and Piston Ring Coated with Molybdenum. Arab. J. Sci. Eng. 2021, 46, 7801-7813. [CrossRef]

133. Liu, Z.; Liang, F.; Zhai, L.; Meng, X. A comprehensive experimental study on tribological performance of piston ring-cylinder liner pair. Proc. Inst. Mech. Eng. Part J J. Eng. Tribol. 2021, 236, 184-204. [CrossRef] 
134. Singh, S.K.; Chattopadhyaya, S.; Pramanik, A.; Kumar, S.; Pandey, S.M.; Walia, R.; Sharma, S.; Khan, A.M.; Dwivedi, S.P.; Singh, S.; et al. Effect of alumina oxide nano-powder on the wear behaviour of $\mathrm{CrN}$ coating against cylinder liner using response surface methodology: Processing and characterizations. J. Mater. Res. Technol. 2022, 16, 1102-1113. [CrossRef]

135. Sonia; Walia, R.; Suri, N.; Chaudhary, S.; Tyagi, A. Potential applications of thermal spray coating for I.C. engine tribology: A Review. J. Phys. Conf. Ser. 2021, 1950, 012041. [CrossRef]

136. Pawlus, P.; Reizer, R.; Wieczorowski, M. Analysis of surface texture of plateau-honed cylinder liner-A review. Precis. Eng. 2021, 72, 807-822. [CrossRef]

137. Patil, A.S.; Shirsat, U.M. Effect of laser textured dimples on tribological behavior of piston ring and cylinder liner contact at varying load. Mater. Today Proc. 2021, 44, 1005-1020. [CrossRef]

138. Ajith Kurian, B.; Rajendrakumar, P.K.; Deepak, K.L. Influence of honing angle on tribological behaviour of cylinder liner-piston ring pair: Experimental investigation. Tribol. Int. 2022, 167, 107355.

139. Ferreira, R.; Almeida, R.; Carvalho, O.; Sobral, L.; Carvalho, S.; Silva, F. Influence of a DLC coating topography in the piston ring/cylinder liner tribological performance. J. Manuf. Process. 2021, 66, 483-493. [CrossRef]

140. Rao, X.; Sheng, C.; Guo, Z.; Zhang, X.; Yin, H.; Xu, C.; Yuan, C. Effects of textured cylinder liner piston ring on performances of diesel engine under hot engine tests. Renew. Sustain. Energy Rev. 2021, 146, 111193. [CrossRef]

141. Grabon, W.; Pawlus, P.; Wos, S.; Koszela, W.; Wieczorowski, M. Evolutions of cylinder liner surface texture and tribological performance of piston ring-liner assembly. Tribol. Int. 2018, 127, 545-556. [CrossRef]

142. Venkateswara Babu, P.; Syed, I.; Ben Beera, S. Experimental investigation on effects of positive texturing on friction and wear reduction of piston ring/cylinder liner system. Mater. Today Proc. 2020, 24, 1112-1121. [CrossRef]

143. Yin, B.; Xu, B.; Jia, H.; Hua, X.; Fu, Y. Experimental research on the frictional performance of real laser-textured cylinder liner under different lubrication conditions. Int. J. Engine Res. 2021, 146808742199529. [CrossRef]

144. Rajput, H.; Atulkar, A.; Porwal, R. Optimization of the surface texture on piston ring in four-stroke IC engine. Mater. Today Proc. 2021, 44, 428-433. [CrossRef]

145. Pawlus, P. Effects of honed cylinder surface topography on the wear of piston-piston ring-cylinder assemblies under artificially increased dustiness conditions. Tribol. Int. 1993, 26, 49-55. [CrossRef]

146. Kikuhara, K.; Koeser, P.S.; Tian, T. Effects of a Cylinder Liner Microstructure on Lubrication Condition of a Twin-Land Oil Control Ring and a Piston Skirt of an Internal Combustion Engine. Tribol. Lett. 2022, 70, 6. [CrossRef]

147. Koszałka, G. Model of operational changes in the combustion chamber tightness of a diesel engine. Eksploat. Niezawodn.-Maint. Reliab. 2014, 16, 133-139.

148. Kordos, P. The influence of the combustion engine work conditions on the cylinder wear in the stand test researches. Eksploat. Niezawodn.-Maint. Reliab. 2006, 32, 11-15.

149. Oil and Your Engine. Available online: https://sos.hastingsdeering.com.au/oil/HDLabServices/pubs/SEBD0640-04 OilAnd YourEngine.pdf (accessed on 5 November 2021)

150. Savc1, I.H.; Şener, R.; Duman, I. A study of signal noise reduction of the mass air flow sensor using the flow conditioner on the air induction system of heavy-duty truck. Flow Meas. Instrum. 2022, 83, 102121. [CrossRef]

151. Dziubak, T. Właściwości eksploatacyjne przepływomierzy powietrza wlotowego silników spalinowych pojazdów mechanicznych. Logistyka 2015, 3, 1217-1226. (In Polish)

152. Przeptywomierz Powietrza z Goraca Warstwa HFM 6; Zeszyt do Samodzielnego Kształcenia nr 358; Volkswagen AG: Wolfsburg, Germany, 2007. (Paper version available in Poland)

153. Przepływomierze Masowe Powietrza. Rozwiązywanie Problemów, Usterki i Testy. Pierburg. Available online: https://static webdealauto.com/images//medias/pdf/0005/pg-si-0079-pl-web.pdf (accessed on 5 November 2021).

154. Myszkowski, S. Przepływomierze powietrza-Rodzaje i uszkodzenia. Serwis Motoryz. 2008, 1, 10-15. (In Polish) 